integral Fast peactor:

Whegralleas pador ANL 1 IIR 257

Thitegral art peactor Thegralleast heactor integral I ast Reactor Titegral rast Reactor Inter ar ir as peactor initegral rast peactor integral Fast Reactor integral Fast Reactor integral I ast Reactor integral Isast Reactor integral Fast heactor integral arst Reactor Integral rast ineactor niegrallast reactor integrall as sineactor integral rast $n$ eac or Integral 1 as a Reactor Integralysast Reactor integral Fastioneator Mregral Fas t reactor thregrall rast heactor integral rasineactor Integral fast Reactor in legralf as theactor 1 integralsast peactor thegral Irastheactor Thiegral ast peactor

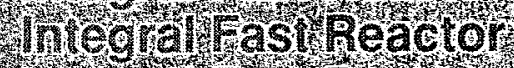
1 mtegral Fastineactor

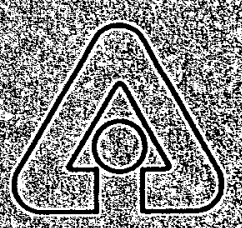

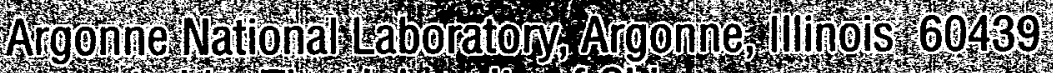

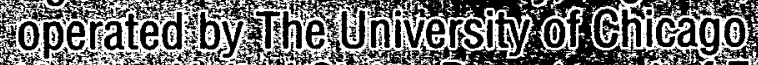

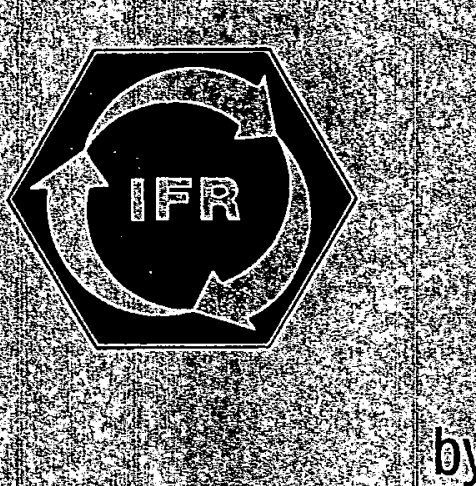

MU16-61935

1.5. Insulation Pestirradiation
Test Report

by W A B ezella, S. Suluntsinan, J. G. Gassulo. R: E H Holtz

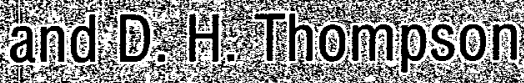

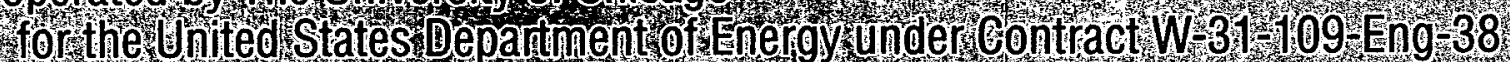

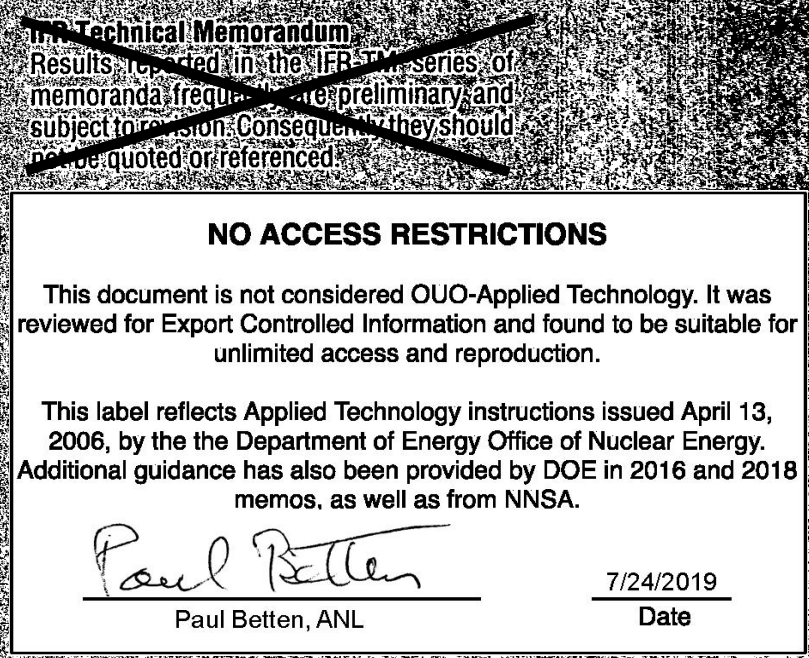




\section{DISCLAIMER}

This report was prepared as an account of work sponsored by an agency of the United States Government. Neither the United States Government nor any agency Thereof, nor any of their employees, makes any warranty, express or implied, or assumes any legal liability or responsibility for the accuracy, completeness, or usefulness of any information, apparatus, product, or process disclosed, or represents that its use would not infringe privately owned rights. Reference herein to any specific commercial product, process, or service by trade name, trademark, manufacturer, or otherwise does not necessarily constitute or imply its endorsement, recommendation, or favoring by the United States Government or any agency thereof. The views and opinions of authors expressed herein do not necessarily state or reflect those of the United States Government or any agency thereof. 


\section{DISCLAIMER}

Portions of this document may be illegible in electronic image products. Images are produced from the best available original document. 


\section{ELECTROMAGNETIC PUMP INSULATION POSTIRRADIATION TEST REPORT}

by

W. A. Bezella, T. S. Huntsman, * J. C. Cassulo, R. E. Holtz, and D. H. Thompson

Reactor Engineering Division Argonne National Laboratory 9700 South Cass Avenue Argonne, Illinois 60439

IFR TECHNICAL MEMORANDUM NO. 257

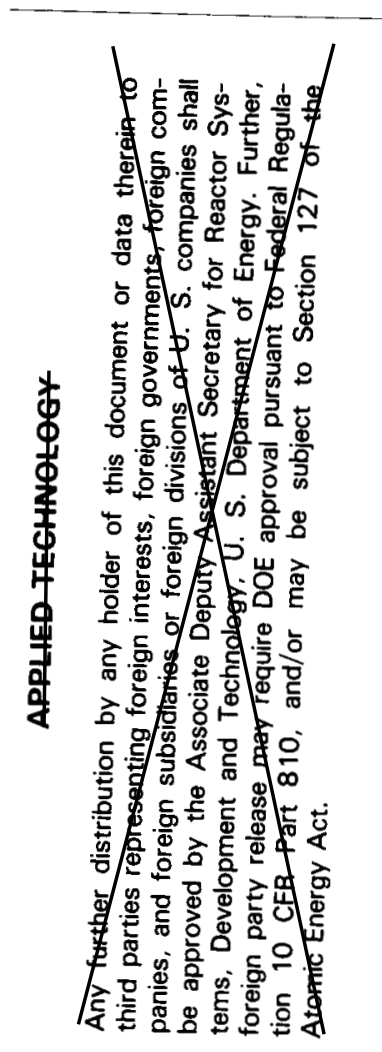

Results reported in the IFR-TM series of memoranda frequently are preliminary and subject to revision. Consequently they should not be quoted or refereneed.

\section{APPLED TECHNOLOGY}

Any further distribution by any holder of this doetment or data therein to third parties representing foreign interests, foreign governments, foreign eompanies, and foreign-subsidiaries or foreign divisions of U.S. eompanies shall-be approred by the Birector for Reator Systems, Bevelopment, and Teehnology, Offiee of Nuclear Energy, U.S. Department of Energy. Further, foreign party release may require- DOE approval purstrant to Federal Regutation 10 CFR Part 810, and/or may be subject to Seetion 127 of the Atomie Energy Aet.

*Integral Fast Reactor-Operations Division, Argonne National Laboratory-West. 
- ij-

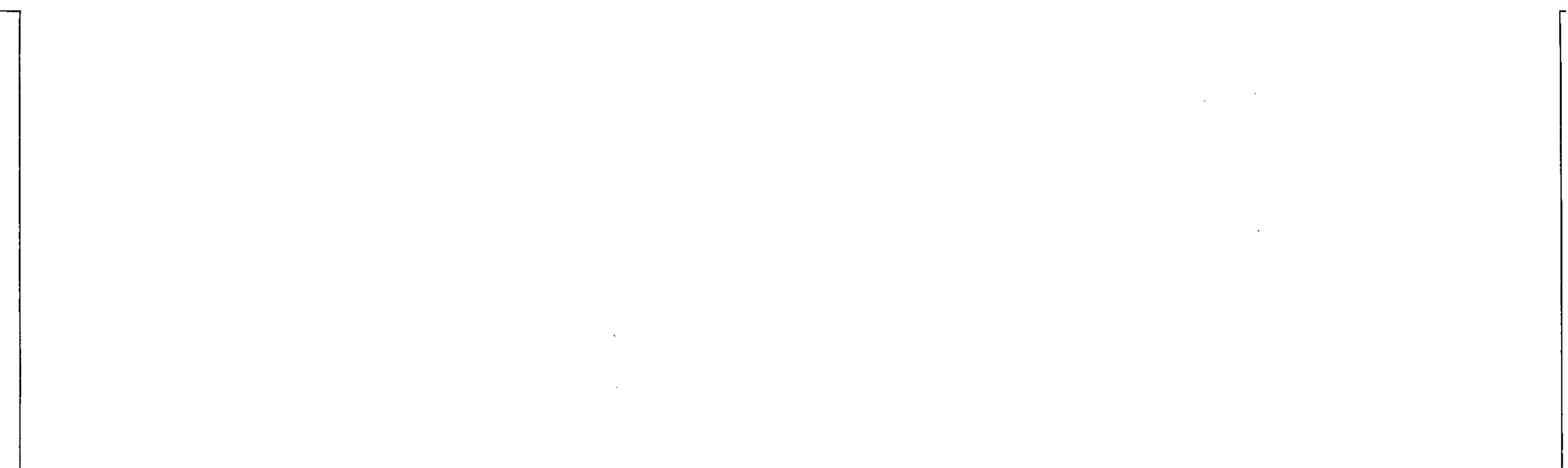


ABSTRACT ........................ ix

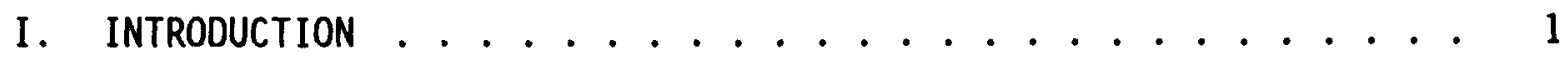

II. EM PUMP INSULATION TEST PROGRAM . . . . . . . . . . 2

A. Preirradiation Test Phase ............. 3

B. Irradiation Testing .............. 5

C. Postirradiation Testing ............. 6

III. DESCRIPTION OF EXAMINATIONS AND TESTS . . . . . . . . 6

A. General Descriptions ............. . 7

B. Physical Examinations ... . . . . . . . . . 8

C. Electrical Testing ................. 11

D. Accelerated Age Testing . . . . . . . . . 13

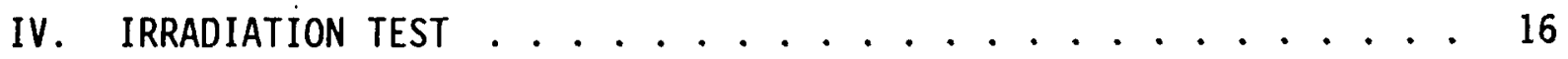

A. Overall Description ............... 16

B. Experiment Assembly ............... 20

C. Assembly Insertion .............. 20

D. Assembly and Bar Sample Removal ............ 25

E. In-reactor Environment . . . . . . . . . . 26

1. Temperature ............... . . 26

2. Radiation ............. 32

v. POSTIRRADIATION TEST RESULTS . . . . . . . . . . 32

A. Physical Examinations .............. 32

1. Description ................ 32

2. Test Results ................. 34

B. Electrical Testing . . . . . . . . . . . 34

1. Description ............... . . 34

2. Test Results ................. 34

C. Accelerated Age Testing ............. . 40

1. Description ............... . . 40

2. Test Results ................. 40

VI. TeMPERATURE TEST ................... 48

A. Overall Description ............... 48

B. Temperature Test History . . . . . . . . . . . 49

C. Pretemperature Test Results .............. 51

1. Physical Examination .............. 51

2. Electrical Testing ............... 53

3. Accelerated Age Testing . . . . . . . . . . 53

D. Posttemperature Test Results . . . . . . . . . . . 53

1. Physical Examination ............ . . 58

2. Electrical Testing ............. . . 64

3. Accelerated Age Testing . . . . . . . . . . 64 
TABLE OF CONTENTS

(Contd.)

Page

VII. SUMMARY OF POSTIRRADIATION TESTS . . . . . . . . . 68

ACKNOWLEDGMENTS .......................... 70

REFERENCES ......................... 70

APPENDIX A. NEUTRON FLUX AND ACTIVITY ESTIMATES . . . . . . . 71

A. Neutron Flux Estimate at Bar Samples . . . . . . . . . 71

B. Activity of General Electric Bar Samples . . . . . . . . 73

APPENDIX B. REPRESENTATIVE PHOTOGRAPHS . . . . . . . . . 77 
1. Splitting Mica Bar Sample Description ........... 9

2. Mica and Ceramic Bar Sample Descriptions .......... 10

3. Axial Locations Where Bar Sample Insulation Thickness is Measured . . . . . . . . . . . . . . . 12

4. Oven Used in Accelerated Aging Tests . . . . . . . . . . . 14

5. Bar Sample Canister Design . . . . . . . . . . . 17

6. Bar Samples in Spacer Holder Being Readied for Loading into Canister . . . . . . . . . . . . 18

7. Bar Samples Inside Canisters in the Glovebox for Filling With Nitrogen and Sealing

8. Arrangement of Canister-carrier Assembly Within the Thimble and Thimble Within Reactor

9. Lower Portion of Canister-carrier Assembly Showing Thermocouples on All Three Canisters

10. Canister-carrier Assembly Positioned for Insertion into Reactor Thimble ............... 23

11. Canister Thermocouple Location to Measure Canister Temperature in EBR-II ............. 24

12. Entire Temperature History for Two Operating Cycles . . . . . 27

13. Cycle 1 Temperature History Amplified . . . . . . . . 28

14. Cycle 2 Temperature History Amplified . . . . . . . . 29

15. Temperature History for Cycle 2 Heatup, Power Operation, Scram and Back to Power

16. Cycle 2 Scram Temperature History Amplified . . . . . . . . 31

17. Canister Radiation Response in EBR-II . . . . . . . . 33

18. Temperature Test Temperature History . . . . . . . . . 52

B1. Toshiba Bar Samples After Irradiation .......... 80

B2. Toshiba Bar Samples After Aging Tests ........... 81 


\section{LIST OF FIGURES}

(Contd.)

Page

B3. General Electric Samples From Canister 1 After Irradiation . . . 82

B4. General Electric Samples From Canister 3 After Irradiation . . . 83

B5. General Electric Samples After Aging Tests . . . . . . . . 84

B6. Bar Samples Before and After Temperature Test ... . . . . 91 


\section{LIST OF TABLES}

Page

I. Aging Test Results of the Six Toshiba Samples . . . . . . . 35

II. Aging Test Results of the 33 General Electric Samples . . . . 35

III. Pre-and Postaging Megger Electrical Testing of Toshiba Samples . . . . . . . . . . . . . 38

IV. Pre-and Postaging Megger Electrical Testing of General Electric Samples . . . . . . . . . . . . 38

V. Pre-and Postaging Hipot Electrical Testing of Toshiba Samples

VI. Pre-and Postaging Hipot Electrical Testing of General Electric Samples................. . 41

VII. Posttest Accelerated Aging Testing of the Toshiba Samples . . . 43

VIII. Posttest Accelerated Aging Testing of the General Electric Samples .. . . . . . . . . . . . 44

IX. Temperature Test Bar Sample Identification . . . . . . . . 49

X. Temperature Test Sequence and Phases . . . . . . . . . . 50

XI. Temperature Test Initial Examinations . . . . . . . . . . 54

XII. Temperature Test First and Second Electrical Measurement Results............... 56

XIII. Temperature Test First Toshiba Aging Test Data . . . . . . . 57

XIV. Temperature Test First General Electric White Mica Aging Test Data . . . . . . . . . . . . . . . . 59

XV. Temperature Test First General Electric Nextel Sample Aging Test Data.................. 6l 61

XVI. Temperature Test Final Examinations . . . . . . . . . . 62

XVII. Temperature Test Third Electrical Measurement Results . . . . 65

XVIII. Temperature Test Fourth Electrical Measurement Results . . . 65

XIX. Temperature Test Second Toshiba Aging Test Data . . . . . . . 66

XX. Temperature Test Second General Electric Aging Test Data . . . 67 


\section{LIST OF TABLES}

(Contd.)

\section{Page}

A1. Neutron Spectrum at Center of Each Canister . . . . . . . . . 72

A2. Activity of General Electric Samples in Canister 1 . . . . . 74

A3. Activity of General Electric Samples in Canister 2 . . . . . 74

A4. Activity of General Electric Samples in Canister 3 . . . . . 75

B1. General Electric and Toshiba Bar Sample Conditions After

Irradiation . . . . . . . . . . . . . . . . . 78 


\title{
ELECTROMAGNETIC PUMP INSULATION POSTIRRADIATION TEST REPORT
}

by

W. A. Bezella, T. S. Huntsman, J. C. Cassulo,

R. E. Holtz, and D. H. Thompson

\begin{abstract}
This report presents the results of the postirradiation test phase of a program dedicated to evaluating the effects of irradiation on the electrical insulation characteristics of samples of insulation proposed for a large annular linear induction pump (ALIP). This electromagnetic (EM) pump is an important component of the Advanced Liquid Metal Reactor (ALMR). As part of the ALMR design verification testing activities, these postirradiation tests are the final phase of the program and focus on the referencing of the insulation bar sample properties after their irradiation in the Experimental Breeder Reactor-II (EBR-II). This report includes a brief description of the test program, the pre and postirradiation test procedures and examinations, and a documentation of the postirradiation test results. This postirradiation report also provides a description of the irradiation test phase and accompanying temperature test. In a previous report, the test results for the preirradiation tests and examinations were documented.
\end{abstract}




\section{INTRODUCTION}

As part of a comprehensive testing program to assess the effects of irradiation on insulation materials proposed for use in the large electromagnetic (EM) pump for the Advanced Liquid Metal Reactor (ALMR), a series of preirradiation tests and examinations were conducted. This report summarizes the results obtained for the final phase of this evaluation test program and includes a description of the centerpiece of the program, which is the irradiation of 39 insulation bar samples in EBR-II. In support of the irradiation activity, an examination and testing effort was conducted to reference and characterize the insulation samples prior to subjecting them to the effects of neutron irradiation. This report documents the test procedures and results obtained for this postirradiation phase of the EM insulation irradiation program which includes a description of the temperature test which subjected some insulation bar samples to conditions identical to those experienced during irradiation but without the radiation component. The preirradiation results along with a detailed catalog of the insulation bar samples was provided in a previous report.[1]

The EM insulation irradiation test program consisted of essentially three distinct phases: (1) a preirradiation test and examination phase, (2) an irradiation in EBR-II phase, and (3) a postirradiation test and examination phase. The pre and postirradiation phases essentially determined the physical characteristics and electrical performance of the insulation in order to determine the effects of irradiation on the electrical insulation behavior. The major feature of the test program was the irradiation phase in which the 39 bar samples contained in three canisters are irradiated for a scheduled 90 full power days in the 32 thimble of EBR-II. The test material envelope consisted of five types of bar samples using four insulation materials, three binder materials and two copper materials. The test temperature specified for the in-reactor test was approximately $850^{\circ} \mathrm{F}$. In the EBR-II J2 test location (i.e., in radial shield outside of the core), a neutron fluence in the range of $1.7 \times 10^{16}$ to $3 \times 10^{17} \mathrm{n} / \mathrm{cm}^{2}$ for the samples with a maximum fluence not to exceed $2 \times 10^{18} \mathrm{n} / \mathrm{cm}^{2}$ is expected. Further details of the irradiation program can be found in Refs. 2 and 3. 
The postirradiation test and examination program was essentially identical to the preirradiation tests and examinations and is presented in Ref. 2. These tests consisted of a series of referencing checks and examinations of the several combinations of insulation materials and binders used in the irradiation phase. In addition, selected insulation bar samples were subjected to an accelerated aging test under high temperature and high voltage to assess the leakage current insulation capability of the material. The electrical performance of each bar sample was determined with Megger and Hipot electrical measurements. This preirradiation test program also served as a screening program in which various insulation material combinations were age tested. The results of this age testing program were used to select the most promising insulation materials for subsequent irradiation testing. Additional details on the preirradiation tests and examinations can be found in Ref. 3 .

This report on the postirradiation tests on EM pump insulation materials is structured as follows. After a brief description of the EM insulation irradiation program provided in Sect. II, the postirradiation tests and examinations that were performed are presented in Sect. III. A description of the irradiation phase of the program that was conducted in EBR-II is presented in sect. IV. The description of the postirradiation characterization data that were obtained is presented in Sect. $V$. The description and test results for the temperature test, which was conducted at conditions similar to those of the irradiation test but without the radiation, are provided in Sect. VI. Finally, in Sect. VII, a summary of the postirradiation results is provided.

\section{EM PUMP INSULATION TEST PROGRAM}

The objective of this program was to assess and confirm the adequacy of candidate insulation materials to perform the electrical insulating function in the EM pump at conditions expected in the ALMR environment. The work involved the irradiation of selected EM pump insulation (bar) samples in a representative neutron flux for a sufficient period of time and then to determine the resulting insulating performance. Exposure of selected insulation materials to a radiation field at elevated temperatures will 
provide some of the performance data necessary to insure that the insulation meets the physical and electrical requirements of the EM pump being designed for the ALMR.

The testing consisted of essentially three phases: a pretesting phase, an irradiation phase, and a posttesting phase. The pre and posttesting phases were designed to establish the effects of radiation on the physical and electrical properties of the insulating materials.

In an attempt to isolate the effects of irradiation, there were essentially four groups of samples that were subjected to various combinations of pretesting, irradiation exposure, and posttesting. The four groups of samples were to be tested in the following combinations:

- Aged, Irradiated/Temperature Tested and Aged

- Aged, Temperature Tested and Aged

- Irradiated/Temperature Tested

- Temperature Tested

The aged tests subjected the samples to an applied voltage in an air atmosphere for a specified time (i.e., up to a maximum of $500 \mathrm{~h}$ ) at a temperature of $1346^{\circ} \mathrm{F}\left(730^{\circ} \mathrm{C}\right)$. These accelerated aging tests were performed on some samples before and after irradiation. Some samples, to aid in the determination of the effects of irradiation, were not irradiated but were subjected to the same duration $\left(-90\right.$ days) and temperature $\left(-1140^{\circ} \mathrm{F}, 616^{\circ} \mathrm{C}\right)$ in a nitrogen atmosphere as those samples being irradiated (Temperature Test).

A brief description of these three program phases is provided in the next three subsections. More details about the EM pump insulation materials irradiation test program can be found in Refs. 2 and 3.

\section{A. Preirradiation Test Phase}

The purpose of the pretesting was to characterize the insulation material both visually and electrically. These examinations and tests served as the reference baseline from which the subsequent irradiation induced changes were 
determined in the posttesting phase of the program. In addition, the preirradiation test phase served as a screening evaluation process for selecting the most promising insulation materials to be irradiated.

The preirradiation testing consisted of the physical and electrical tests needed to benchmark the insulation samples prior to the irradiation phase of the program. These tests were essentially identical to those conducted in the postirradiation test phase and include visual examinations, photographs, physical measurements, voltage/temperature aging tests, and electrical tests. The examinations and physical evaluations included determining the weights and dimensions of each bar sample. The crystalline structure analysis specified in Ref. 2 was not performed.

The electrical tests that were performed included both a direct current resistance test as well as an alternating current leakage current test. Other special electrical tests (i.e., partial discharge, loss tangent, and breakdown voltage) as originally specified in Ref. 2 were not performed due to their projected expense.

The accelerated aging tests were short duration, high temperature and voltage tests performed in an oven. The test setup and conditions were similar to those used in the past for the ALMR EM pump insulation materials life testing program at ANL-East. The bar samples were placed in an oven in an air atmosphere. A high voltage (e.g., either $600 \mathrm{~V} A C$ or $1500 \mathrm{VAC}$ depending on the bar sample type) was applied to the insulation and the leakage to ground current monitored. The temperature for these accelerated aging tests was $1346^{\circ} \mathrm{F}\left(730^{\circ} \mathrm{C}\right)$, with the test duration being $500 \mathrm{~h}$ (approximately three weeks) or $350 \mathrm{~h}$ (approximately two weeks) depending on the sample type.

As part of the preirradiation test phase, several shorter duration ( 1 day) aging tests were conducted. These tests were essentially conducted to check out the performance of new combinations of insulating materials. Based on the results, the most promising insulation materials were selected for irradiation. 
The procedures and preirradiation test specifics are presented in more detail in Sect. III and in Ref. 2. The preirradiation test results are reported in Ref. 1

\section{B. Irradiation Testing}

The irradiation program was conducted in the J2 thimble of EBR-II. This irradiation facility, called the Nuclear Instrument Test Facility (NITF), is located outside the core in the shield region and is an air-cooled thimble. The 39 selected bar samples were contained in three stainless-steel canisters (13 samples in each canister); this $\mathrm{J} 2$ thimble test was designated the NI-10 test. The canisters were filled with nitrogen gas and sealed initially at one 1 atm pressure. The temperature histories of the three canisters were recorded by two thermocouples attached to each canister. The neutron flux at the three canister locations was determined by a neutronic calculation. The experimental determination of the neutron flux was not possible as sufficient funding was not available. The duration of the irradiation phase of the program was specified as 90 days, however, this requirement was adjustable depending on the EBR-II irradiation cycle schedule. Based on the latest EBRII fuel cycle projections, an irradiation duration of 292.5 days was obtained for the EM insulation bar samples in the NI-10 EBR-II irradiation test.

In conjunction with the irradiation of the bar samples, a temperature test was conducted in an oven at ANL-East. Using an identical fourth canister, 13 bar samples were inserted and sealed in a nitrogen atmosphere. This canister was $\mathrm{placed}$ in an oven at the highest irradiation canister temperature observed in the EBR-II irradiation $\left(1140^{\circ} \mathrm{F}, 616^{\circ} \mathrm{C}\right)$ and was operated at this temperature for the same duration as the irradiation samples (estimated to have been -92.5 days). A comparison of the insulation electrical performance of these samples with that of the irradiated samples should help identify the influence of the irradiation on electrical insulation behavior.

Further details on the specifics of the irradiation aspects of the EM pump insulation irradiation program can be found in Ref. 3 . 


\section{Postirradiation Testing}

The postirradiation testing phase essentially was a repeat of the series of examinations and tests conducted during the preirradiation phase (see Sect. II.A). The major difference between the two phases, of course, being the fact that in this testing phase the samples are slightly radioactive. This factor has several implications on the resulting methods and test procedures that are employed in the posttesting phase. The activity level of the irradiated bar samples was measured and estimated analytically. In addition, three typical insulation bar samples were irradiated in a special test capsule in the Neutron Radiation (NRAD) test facility at ANL-West (see Ref. 1 for details). Based on an assessment of these results, the required decay time and adjusted test procedures were established. It was decided that these postirradiation examinations, accelerated age tests and electrical tests would be performed at ANL-West, which was better equipped to deal with radioactive materials than is ANL-East.

\section{DESCRIPTION OF EXAMINATIONS AND TESTS}

The postirradiation examination and test phase of the EM insulation irradiation test program as presented in detail in Ref. 2 is summarized briefly below. Because of high sample activity level and monetary constraints, not all of the electrical tests as specified in Ref. 2 were performed. In addition, the original sample matrix was expanded to incorporate other combinations of insulating/binder materials. These tests were essentially identical to the preirradiation tests and examinations, the results of which are reported in Ref. 1 .

Summarized briefly below are the general descriptions and compositions of the various insulation bar samples studied in this EM pump insulation irradiation program. The various preirradiation examinations and tests are also described. The actual postirradiation data are presented and discussed in Sects. V and VI. 


\section{A. General Descriptions}

The bar samples evaluated in this program consisted of a copper bar wrapped with an insulation material and held together with a binder material. Five types of bar samples, approximately $10 \mathrm{in.}$ long, using four insulation materials, three binder materials tested and two copper materials comprised the materials test matrix. The two copper materials tested were GlidCop AL-15 (C15715) and Electrolytic Tough Pitch (ETP) Copper (C11000). The four insulation materials are splitting mica, muscovite (white mica), phlogopite (amber mica), and Nextel ${ }^{\mathrm{M}}$ (a ceramic tape from 3M Corp.). Three types of potting compounds were used as a binder to hold the insulation together on the copper bar; one binder developed by the Corning Co. consisted primarily of silicon and aluminum, the second binder was SECON-5 (its main constituents are oxides of silicon, lead and aluminum), and the third binder was boron nitride, comprised primarily of boron nitride, aluminum oxide.

The insulation bar samples were fabricated by either the General Electric (GE) Co. or the Toshiba Corp. with different materials and slightly different dimensions. Figure 1 illustrates the splitting mica bar sample or Toshiba design. A total of 19 insulation bar samples of this design were included in the program. These 19 samples were designated by a single digit (i.e., 1 to 19). As Fig. 1 indicates, these splitting insulation bar samples were $280 \mathrm{~mm}$ ( 11 in.) long with several layers of mica wrapping. The cross-sectional dimensions shown for the outside of the insulation are approximate with actual dimensions measured as part of the preirradiation (see Ref. 1) and postirradiation examinations (e.g., see Sects. V and VI). The silicon binder was used only on the ends of the top layer to anchor the alumina tape (i.e., splitting mica).

The General Electric insulation bar sample design is described in Fig. 2, this bar sample's overall length is $10 \%$ in. $(254 \mathrm{~mm})$ with the insulation length being about $10 \mathrm{in.}(254 \mathrm{~mm})$. As specified in the notes on Fig. 2, there were several insulation combinations fabricated to this GE bar sample design. The 21 amber mica/S'econ-5 insulation bar samples were designated with numbers G1 through G20 and G43. The 22 white mica/Secon-5 insulation bar samples were designated with numbers G21 through 642. Several amber 
mica/boron nitride samples were also included in the program (numbers $1 A, 2 A$, etc.) as well as Nextel/boron nitride insulation bar samples (numbers N10 through $\mathrm{N} 19$ ). In addition, several special combination insulation samples (i.e., different wraps of mica and ceramic tape and different binders) were added to the program. These samples had a sample bar designation identified with a "C" classification or a sample number in the 90 range. Again the cross-sectional dimensions shown in Fig. 2 are approximate with the actual dimensions for each GE bar tabulated for the preirradiation phase in Ref. 1 and for the postirradiation phase in Sects. $V$ and VI.

The description of the various types of standard insulation bar sample materials (i.e., those samples in the original test matrix of Ref. 2) and approximate typical weights are tabulated in Table I of Ref. 1 . Identified also in the Appendix of Ref. 1 are the associated weights (percents and approximate total weights) and compositions of the copper bars, insulation and binders. The weights are based on a typical insulation bar and represent average values for use in the irradiation evaluations (e.g., neutron activation calculations).

The description and numbering key of the various special insulation bar samples is shown in Table II of Ref. 1. As requested by GE, these ceramic tape insulation (i.e., Nextel tape) and a combination of ceramic tape and mica tape insulation using various binders were added to the test program. They were mainly subjected to an accelerated age test of varying duration. Based on their performance in these tests, several of these ceramic insulation/binder sample combinations were selected to replace some of the white mica insulation samples in the EBR-II irradiation test.

\section{B. Physical Examinations}

As part of the preirradiation phase of the program, each bar sample was visually examined and a photograph taken to provide a visual record of its overall condition. Most of the samples were subjected to weight and dimensional measurements. Prior to taking these measurements, the samples were kept in an oven at $-120^{\circ} \mathrm{F}\left(49^{\circ} \mathrm{C}\right)$ for several days in order to control the moisture level. To prevent the insulation tape from unraveling for some 


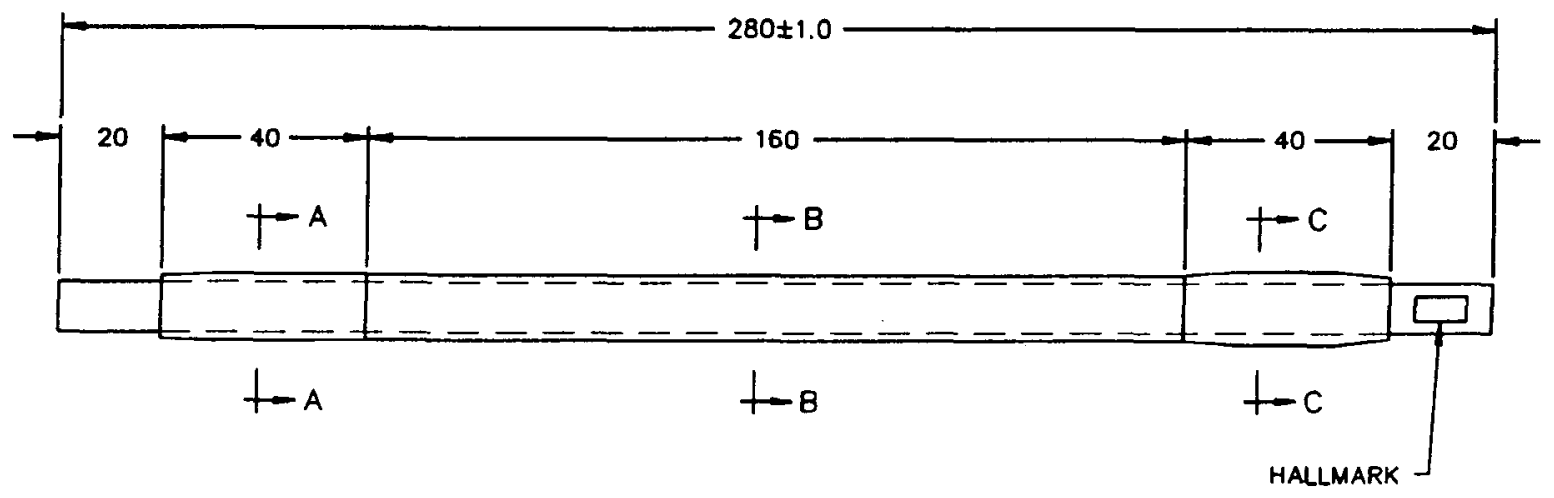

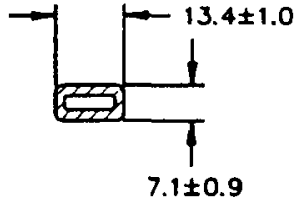

SECTION A-A

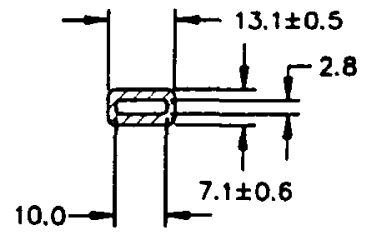

SECTION B-B

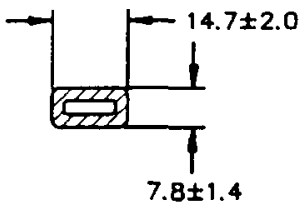

SECTION C-C

Notes: 1. Dimensions are in millimeters $(\mathrm{mm})$.

2. Cross sections are rotated $90^{\circ}$.

3. Bar is made with Aluminum Dispersion Strengthen Copper, Glidcop, AL-15 (C15715).

4. Alumina cloth backed amber splitting mica tape $(0.3 \mathrm{~mm}$ thick, 25 $\mathrm{mm}$ wide) is $2 / 3$ lapped one layer with a silicone binder on bar, underside of tape and on outside of layer. Alumina tape $10.2 \mathrm{~mm}$ thick, $25 \mathrm{~mm}$ wide) is $1 / 2$ lapped one layer as top layer for protection. Silicone binder is used only on ends of top layer for protection. Silicone binder is used only on ends of top layer to fix alumina tape.

5. Bar sample numbers 1 through 19.

Fig. 1. Splitting Mica Bar Sample Description 

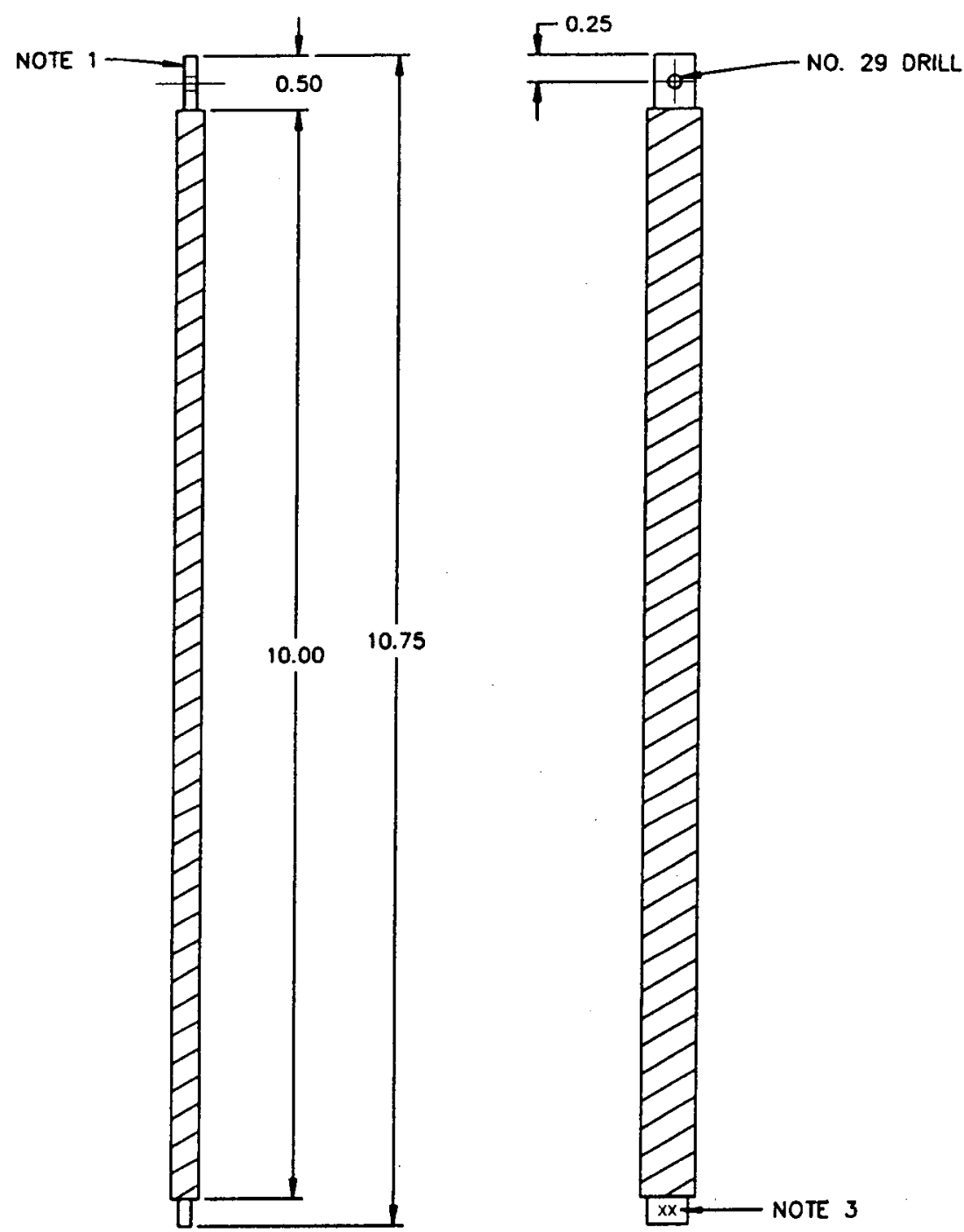

Notes: 1. Bar is made with 0.115 in. $x 0.376$ in. flat copper wire $\mathrm{C} 11000$ Electrolytic Tough Pitch Copper, dimensions in in.

2. Insulation descriptions: 21 bar samples (Numbers G1 through G20 and G43) wrapped with amber mica/Secon 5, 21 bar samples (Numbers G21 through G42 wrapped with white mica/Secon 5, wrapped with amber mica/boron nitride (Numbers $1 A$ and $2 A$ ), Nextel 440/boron nitride (Numbers N10 through N19) and special combinations B series and 91, 93 and 97.

3. The bar number is stamped on each bar at the location indicated.

Fig. 2. Mica and Ceramic Bar Sample Descriptions 
samples, a thin ceramic thread was tied around the ends of some of the bars. In these examinations, the width and thickness of the bar sample including the insulation were recorded. The thickness dimensions were made at five places along the bar at approximately equally spaced places over its insulated length. These dimensions were obtained to the nearest 0.01 of an inch $(0.254$ $\mathrm{mm}$ ). Figure 3 indicates the axial locations where the bar sample insulation thickness is measured. The weight of each bar that was weighed (some were not because they were still wet and required curing) was recorded to the nearest 0.01 of a gram.

The crystalline structure analysis as specified in the original test requirements document (see Ref. 2) was not carried out. This test was to consist of preparing a cross section of the insulation for two samples of each mica type (i.e., white, amber and splitting) and then examining and photographing the samples under magnification using the scanning electron microscope (SEM).

\section{Electrical Testing}

The preirradiation electrical testing of the insulation bar samples consisted of two tests; (1) a Megger test and (2) a Hipot test. These are standard electrical tests universally performed to determine the electrical resistance of materials. For both of these tests, the bar sample's insulation was wrapped with a thin sheet of aluminum foil to insure that good contact was achieved between the insulation and the electrode. In both of these tests a consistent procedure regarding the preparation of the sample, location of the electrodes and recording of the data was maintained for every sample. A11 samples were kept in an oven at $\sim 120^{\circ} \mathrm{F}\left(49^{\circ}\right)$ for several days prior to these tests to insure that the samples were dry and not subjected to differing levels of sample moisture.

Megger Test: The Megger test consisted of measuring the insulation electrical resistance by attaching the hot electrode to the bar and the ground electrode to the outside of the insulation. In this test, $1000 \mathrm{~V} D C$ was applied for about $1 \mathrm{~min}$ and the resistance recorded in gigaohms. This test was performed with the bar sample at room temperature. 


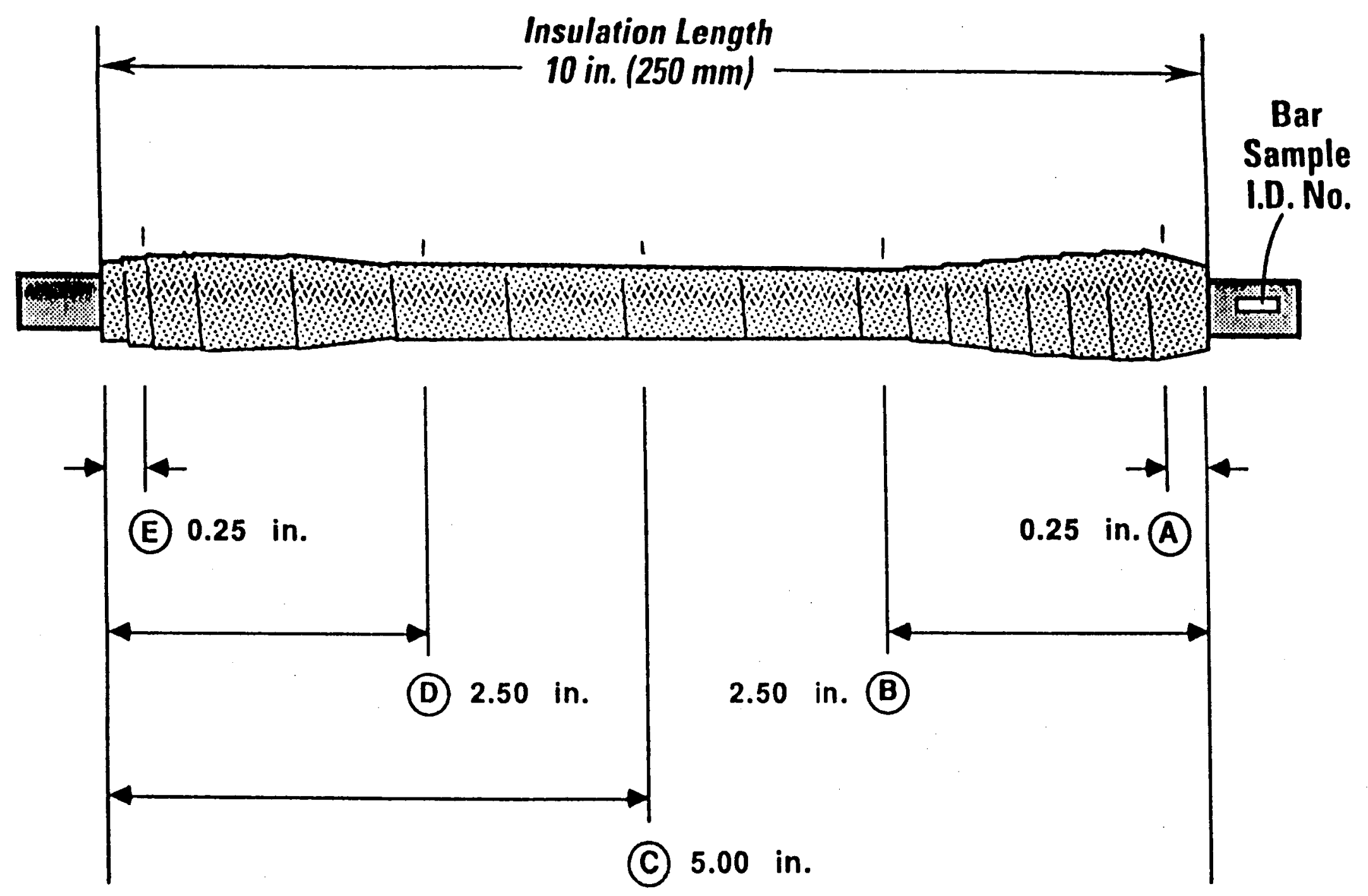

Fig. 3. Axial Locations Where Bar Sample Insulation Thickness is Measured 
Hipot Test: The Hipot (high potential) test was performed at $3000 \mathrm{~V} \mathrm{AC}, 60$ $\mathrm{Hz}$ at room temperature. The meter electrodes were attached as in the Megger test; the voltage was applied for about $1 \mathrm{~min}$. The leakage current was recorded for each sample in milliamps.

\section{Accelerated Age Testing}

All of the accelerated age tests on the insulation bar samples were conducted in the specially fabricated ovens which were designed at ANL-East. The accelerated age testing of the slightly radioactive bar samples irradiated in EBR-II was performed in an oven at ANL-West which was shipped from ANLEast. The test setup and procedures were almost identical to those used in the insulation life testing currently underway at ANL-East on the U.S. ALMR EM pump insulation life testing program.

Figure 4 presents an illustration of the typical oven that was used in the accelerated aging tests. The ovens have inside heater compartment dimensions of approximately $18 \mathrm{in}$. by $18 \mathrm{in}$. by $6 \frac{1}{2}$ in. $(45.7 \mathrm{~cm} \times 45.7 \mathrm{~cm} \times 16.5 \mathrm{~cm}$ ) and are constructed of fire brick with an outside sheath of Kaylo. The oven top consists of two layers of $1 \mathrm{in} .(2.54 \mathrm{~cm})$ thick Fiberfrax. Four small plate two heaters, 14 in. $x 5 \frac{1}{2}$ in. $x \%$ in. $(35.6 \mathrm{~cm} \times 14.0 \mathrm{~cm} \times 1.6 \mathrm{~cm})$, supply the heat from a $208 \mathrm{~V}$ power supply. The outside dimensions of the oven are about 30 in. $\times 30$ in. $\times 14$ in. $(76.2 \mathrm{~cm} \times 76.2 \mathrm{~cm} \times 35.6 \mathrm{~cm})$. The heater electrical leads were brought out through the sides of the oven bricks through 6 in. $(15.2 \mathrm{~cm})$ ceramic sleeves. The electrical leads for the applied sample voltage were brought out through the oven top cover. Temperature control was provided with a thermocouple connected to a temperature controller/recorder. A voltage transformer provided the applied voltage to the sample with sample leakage current measured with an ammeter. A 62 milliamp fuse in the leakage current circuit provided sample insulation failure indication and interrupted the applied sample voltage. 

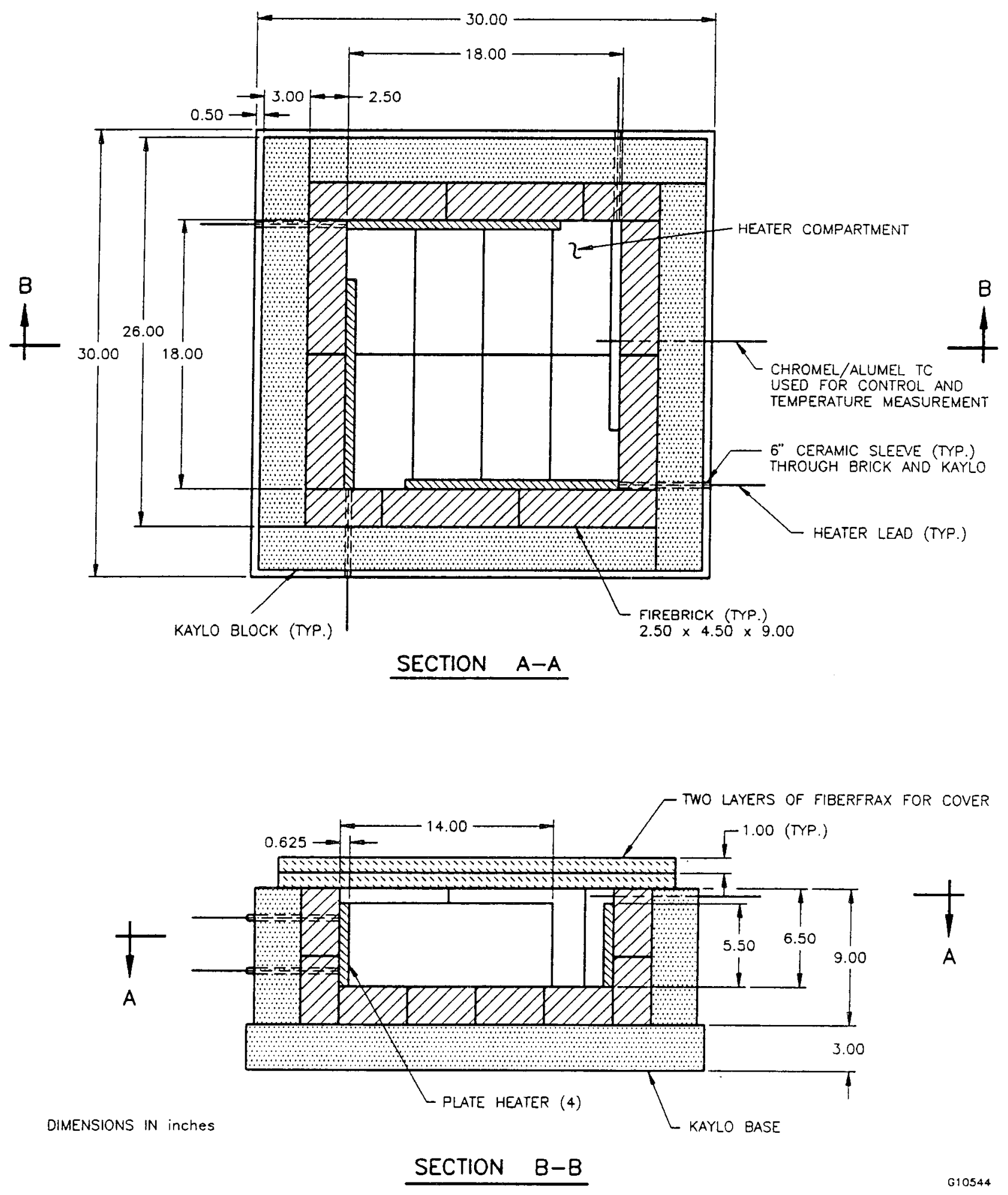

Fig. 4. Oven Used in Accelerated Aging Tests 
As specified in Ref. 2, the original preirradiation test matrix called for short-term aging tests for $500 \mathrm{~h}$ with applied voltages of $600 \mathrm{~V}$ AC for the splitting mica samples and $1500 \mathrm{~V} A C$ for the white and amber mica samples. For the aging tests of the special ceramic tape samples, a voltage of $1500 \mathrm{~V}$ $A C$ was also applied. All aging tests were conducted in air with the oven temperature set at $-1340^{\circ} \mathrm{F}\left(727^{\circ} \mathrm{C}\right)$.

The bar sample preparation and oven loading procedure was essentially unchanged from that used in the ALMR EM pump insulation life testing program. Several bars (e.g., four or five) were clamped between two unoxidized stainless-steel plates. The applied voltage terminals were attached to the plates and to each bar sample. In the case of the bar leads, the attachment was at a small set screw located at one end of each copper bar (No. 29 drill hole). To insure good electrical contact for the previously cured insulation bar samples, a $0.001 \mathrm{in.}(0.025 \mathrm{~mm})$ thick foil of stainless steel was wrapped tightly around the outside of the insulation and fixed at each end with stainless-steel wire. Depending upon the number of samples, several of these bar sample-plate sandwiches were stacked one on top of each other forming a test matrix. The maximum oven loading was about 24 bar samples.

The oven heatup and approach to full applied voltage was done in a gradual and controlled manner. With the samples placed in the oven and the equipment and power and voltage leads and supply equipment checked out, the oven was heated to $125^{\circ} \mathrm{C}$ and held at that temperature overnight to remove any residual sample moisture. The oven temperature was then raised gradually at a maximum rate of $100^{\circ} \mathrm{C} / \mathrm{h}$ until the specified $1345^{\circ} \mathrm{F}\left(-730^{\circ} \mathrm{C}\right)$ aging temperature was reached. In some cases, depending upon the type of samples and their condition (i.e., cured or uncured) a hold for several hours at a specified temperature $\left(\mathrm{e.g}, 500^{\circ} \mathrm{C}\right.$ ) was required to ensure that complete sample curing was obtained. With the oven at the reference aging temperature, the voltage was applied across the bar samples, also in an incremental manner, at a maximum of $250 \mathrm{~V}$ per step (rate of voltage increase was just long enough to record all of the sample's leakage currents). This startup phase generally took several days to complete. 
Several aging tests were conducted during the preirradiation phase of the program. The original accelerated tests specified in Ref. 2 were slightly modified in order to phase in additional Nextel ceramic tape samples into the program. Therefore, only the splitting mica samples were tested to the specified $500 \mathrm{~h}$. The other white and amber sample aging time was shortened to $\sim 350 \mathrm{~h}$. Other aging tests on the special Nextel and combination insulation materials had aging tests which varied from 270 to $336 \mathrm{~h}$. In addition, very short 1 day aging tests were conducted to assess quickly the performance of bar samples to be inserted in the temperature test.

The data from the aging tests were recorded on a daily basis once the reference applied voltage and temperature had been reached. The oven temperature, the applied voltage, and the sample leakage current were recorded. Also photographs of the samples installed in the oven and the overall test setup were taken for the archival record.

\section{IRRADIATION TEST}

\section{A. Overall Description}

Irradiation of the bar samples occurred in the $\mathrm{J} 2$ thimble of the EBR-II reactor. For in-reactor irradiation testing, the bar samples were $\mathrm{placed}$ in a canister made from stainless steel. The canister design and general features are shown in Fig. 5. Internal to the canister was a spacer frame for separating the individual bar samples. After the samples were loaded into the canisters, the canisters were placed in a special glovebox and filled with nitrogen. The glovebox was purged and filled with nitrogen several times to assure removal of air. While in the glovebox, the covers were screwed on the canisters. Sealing was accomplished by means of a metal 0-ring. Photographs of the bar sample loading and gas filling in the glovebox are shown in Figs. 6 and 7. 


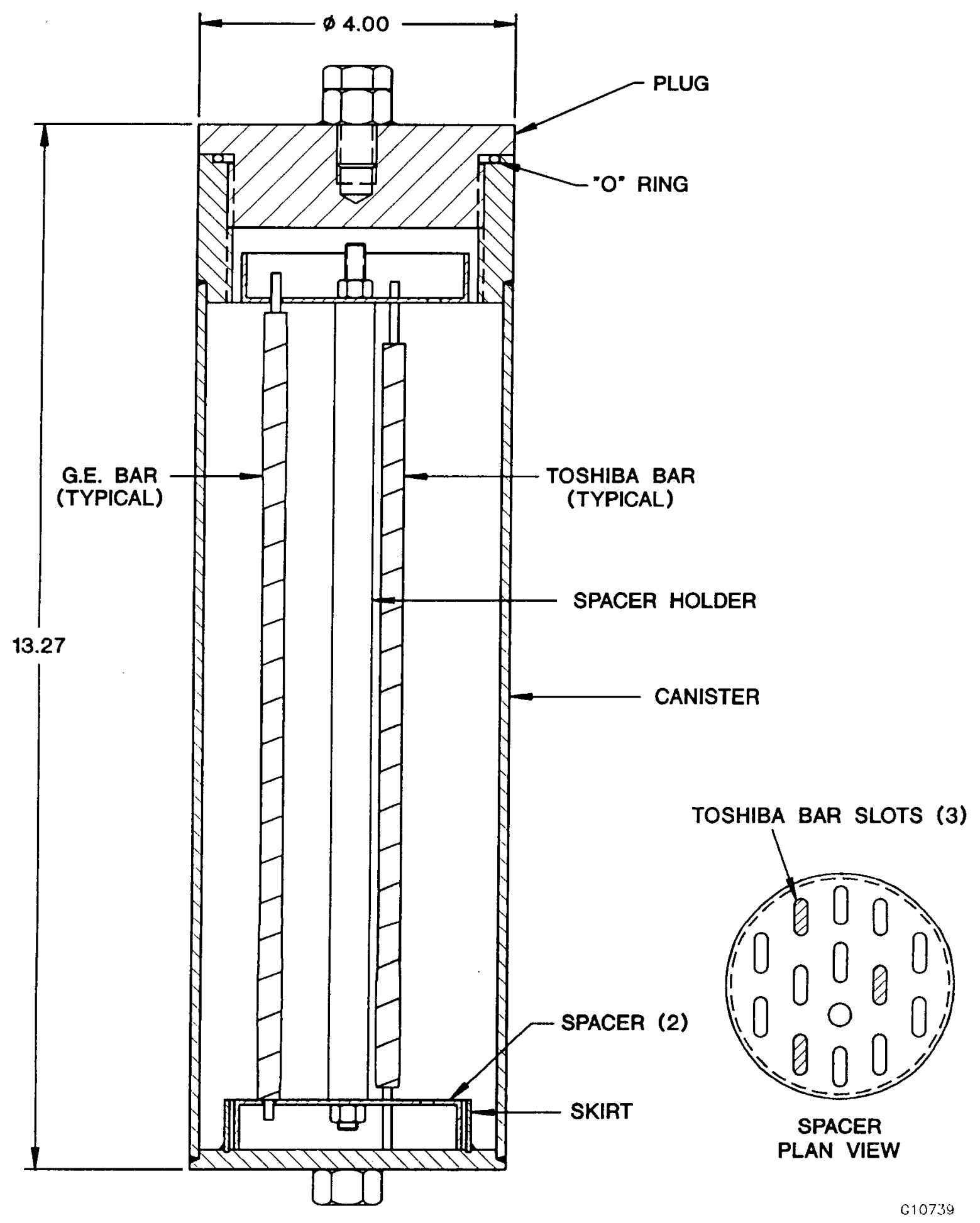

Fig. 5. Bar Sample Canister Design 


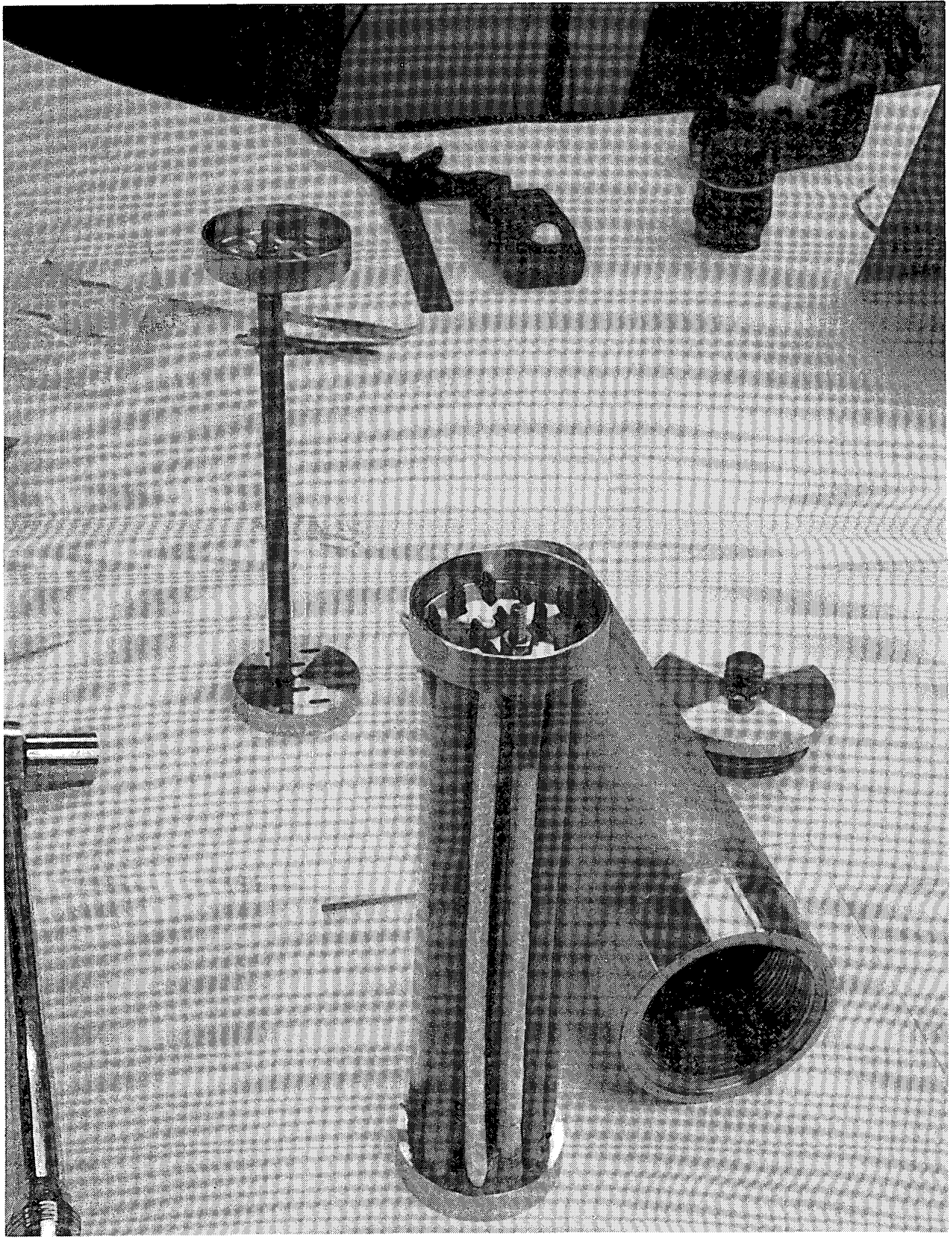

Fig. 6. Bar Samples in Spacer Holder Being Readied for Loading into Canister (ANL-West Neg. No. DD5215) 


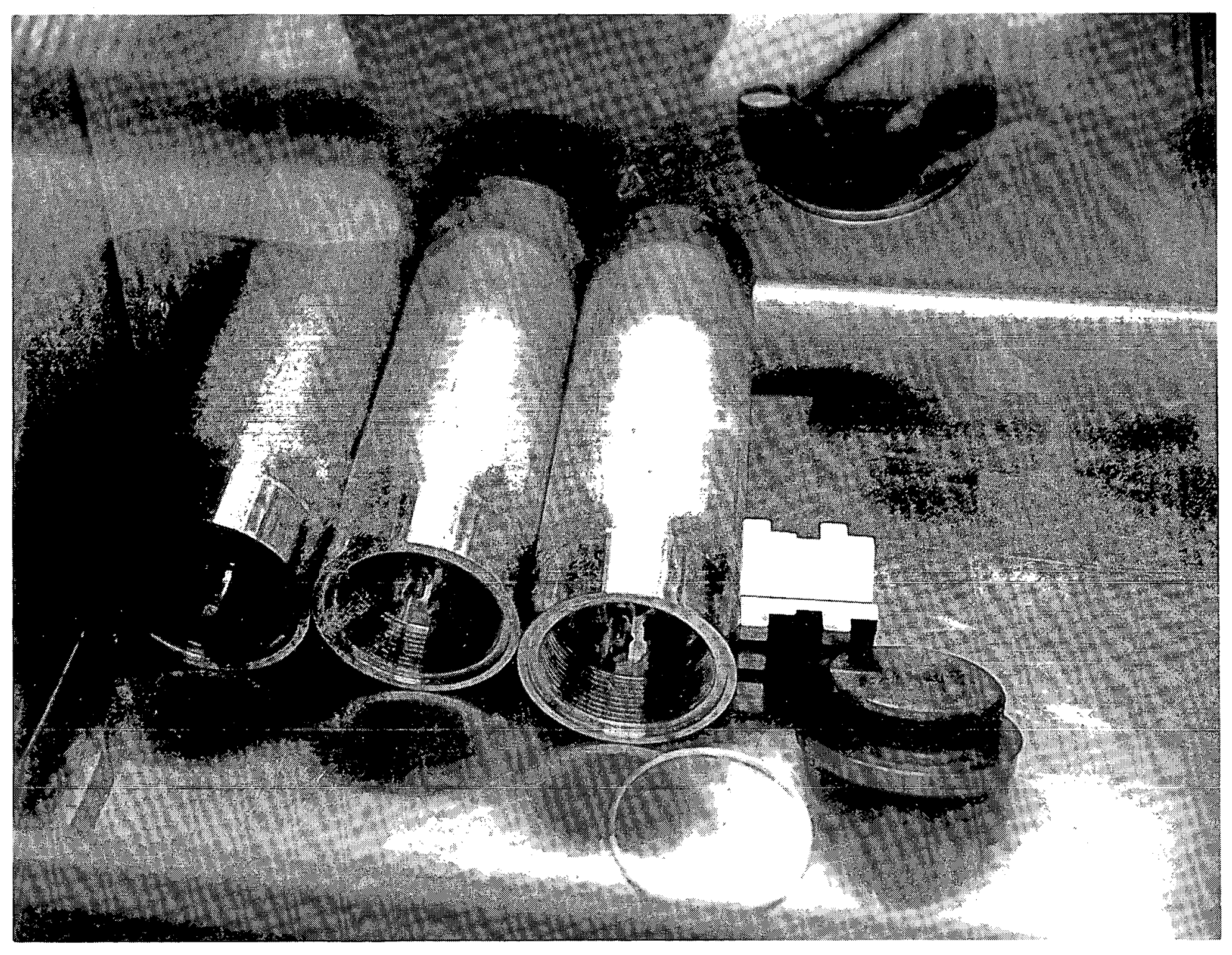

Fig 7. Bar Samples Inside Canisters in the Glovebox for Filling With Nitrogen and Sealing (ANL-West Neg. No. DD5212) 


\section{B. Experiment Assembly}

Three canisters were used for the irradiation portion of the experiment. Each canister contained 13 bar samples. The canisters were held by a canister-carrier assembly that provided the means for inserting them into the reactor and positioning them near the core. The arrangement of the canistercarrier assembly within the $\mathrm{J} 2$ thimble and the thimble within the reactor is illustrated in Fig. 8. Photographs of the canister-carrier assembly are shown in Figs. 9 and 10. The lower portion of the canister-carrier assembly with the three canisters held within the carrier is shown in Fig. 9. The entire canister-carrier assembly as it was positioned for insertion into the reactor thimble is shown in Fig. 10.

The temperature histories of the three canisters were recorded by two thermocouples (see Fig. 11) attached to each canister. The neutron flux at the three canister locations was determined by a neutronic calculation. As expected, the top canister was subjected to a specified low fluence and the bottom canister to a high fluence.

\section{Assembly Insertion}

The lower carrier, which contained the three sample canisters, was assembled to the upper carrier. Two thermocouples were secured to the outside center of each sample canister on opposite sides (one toward the core location and one opposite).

The completed NITF J2 carrier assembly was ready for insertion into the EBR-II Reactor J2 thimble on July 23, 1993. On Monday, July 26, the assembly was attached to the reactor building crane and raised over the $\mathrm{J2}$ thimble. Insertion was accomplished relatively slowly to prevent thermal shock to the assembly. Once the experimental assembly was secured in place, the thermocouple leads were connected for immediate readings. All thermocouples responded properly. EBR-II started up for Run No. 165A on July 29. Reactor criticality was reached at $1726 \mathrm{~h}$. The reactor was at full power of $62.5 \mathrm{MW}$ on July 31 at $1742 \mathrm{~h}$. Run No. 165A concluded at $1748 \mathrm{~h}$ on October 7 . This run resulted in 66.0 effective full power days (EFPD). 


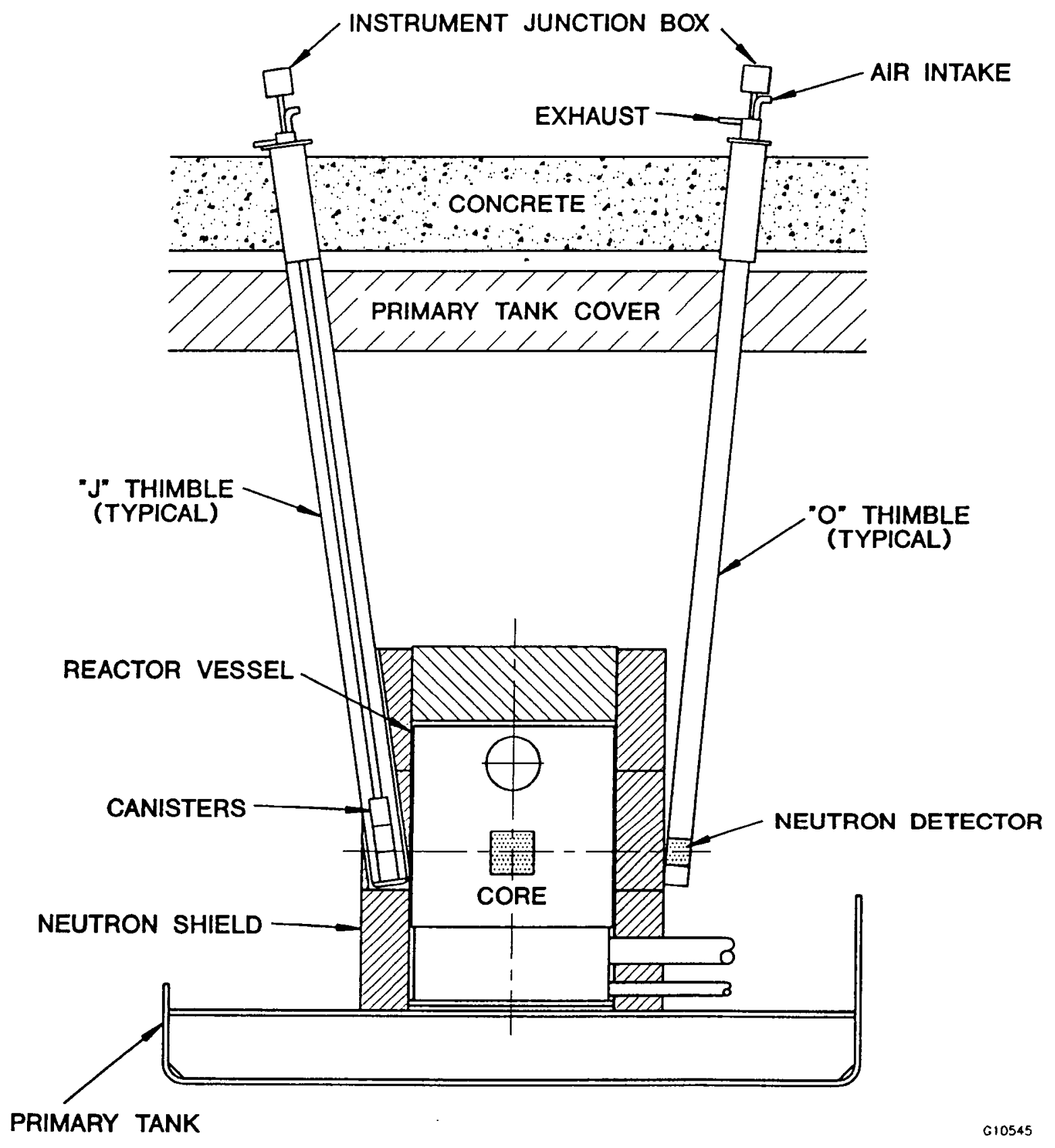

Fig. 8. Arrangement of Canister-carrier Assembly Within the Thimble and Thimble Within Reactor 


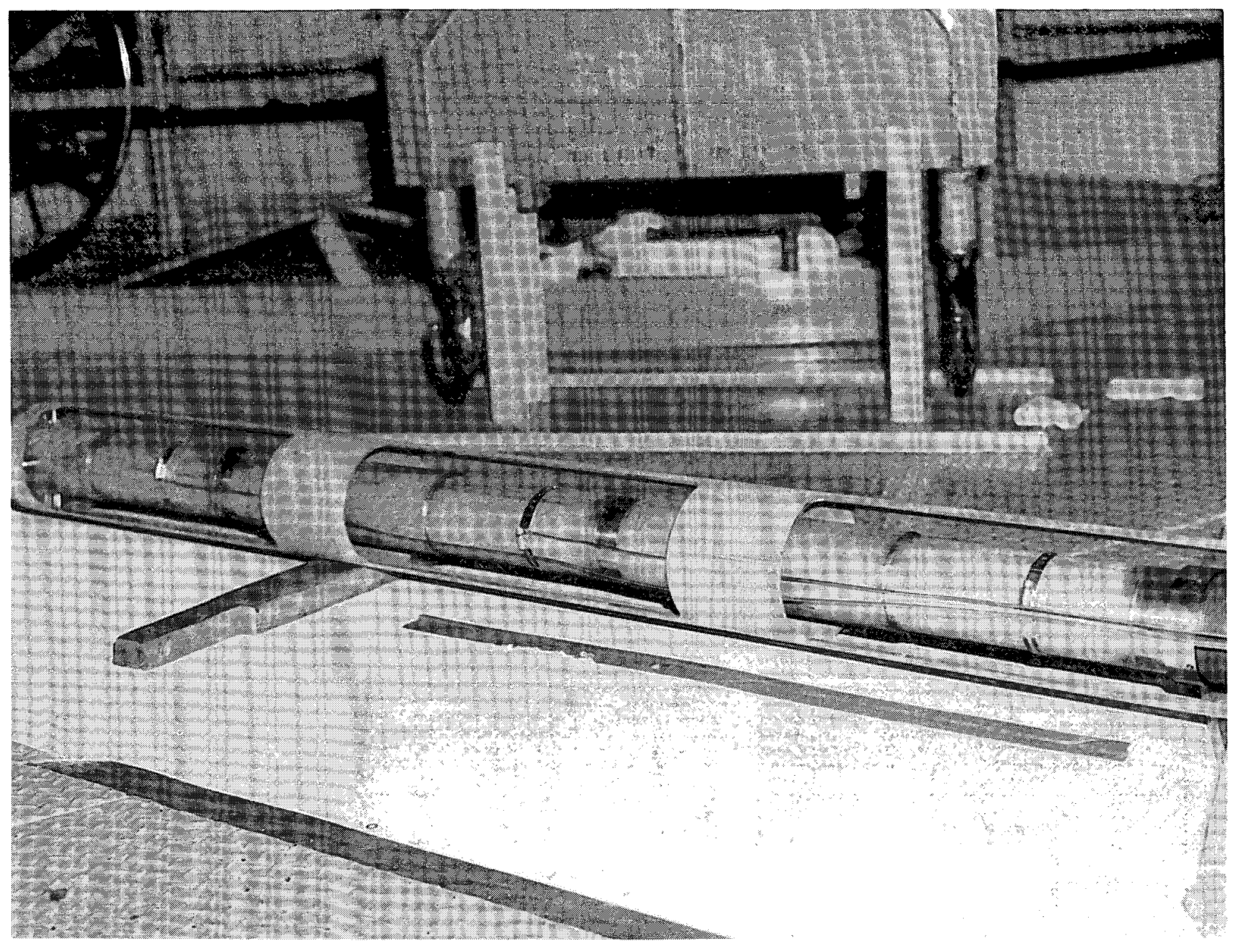

Fig. 9. Lower Portion of Canister-carrier Assembly Showing Thermocouples on All Three Canisters (ANL-West Neg. No. DD5220) 


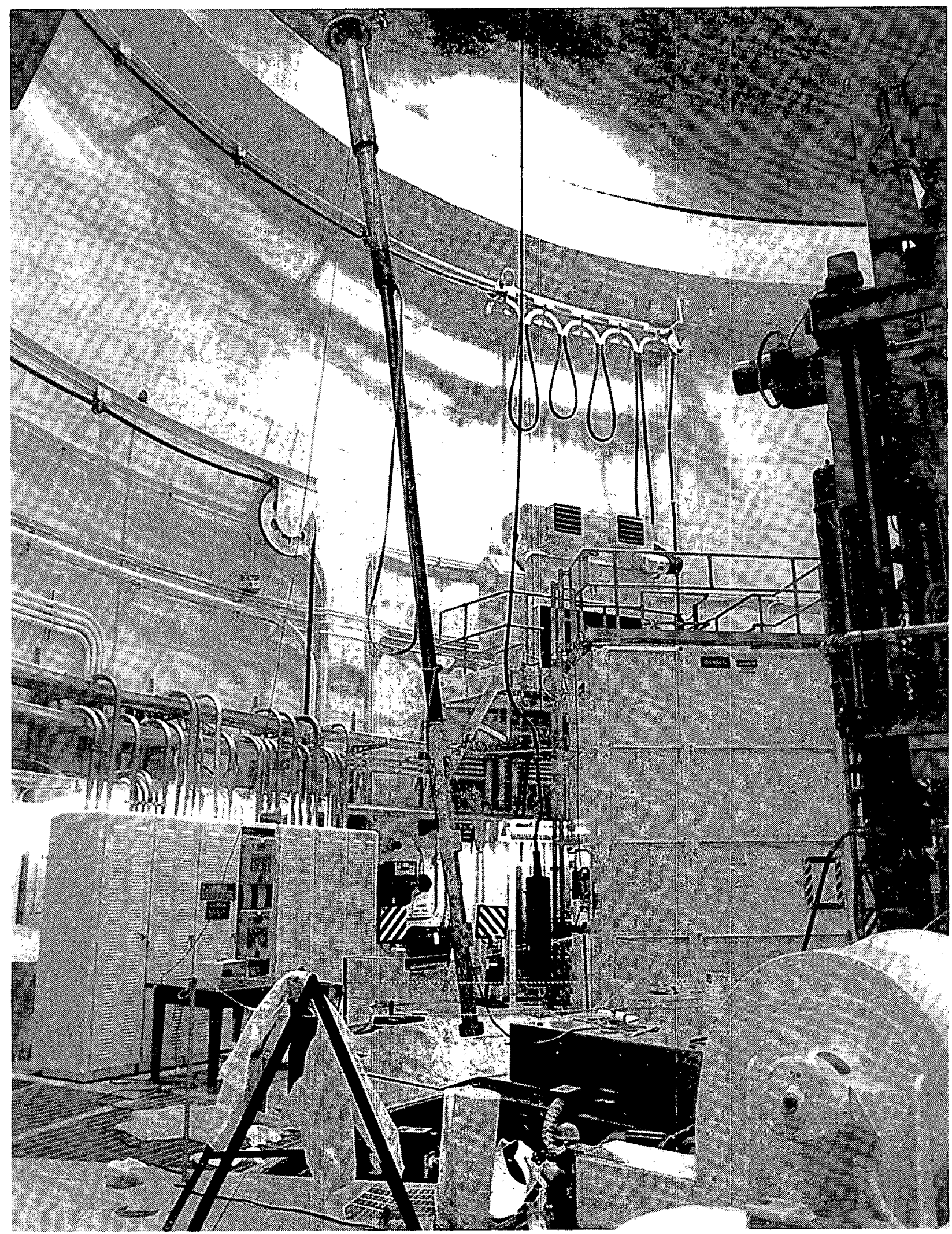

Fig. 10. Canister-carrier Assembly Positioned for Insertion into Reactor Thimble 


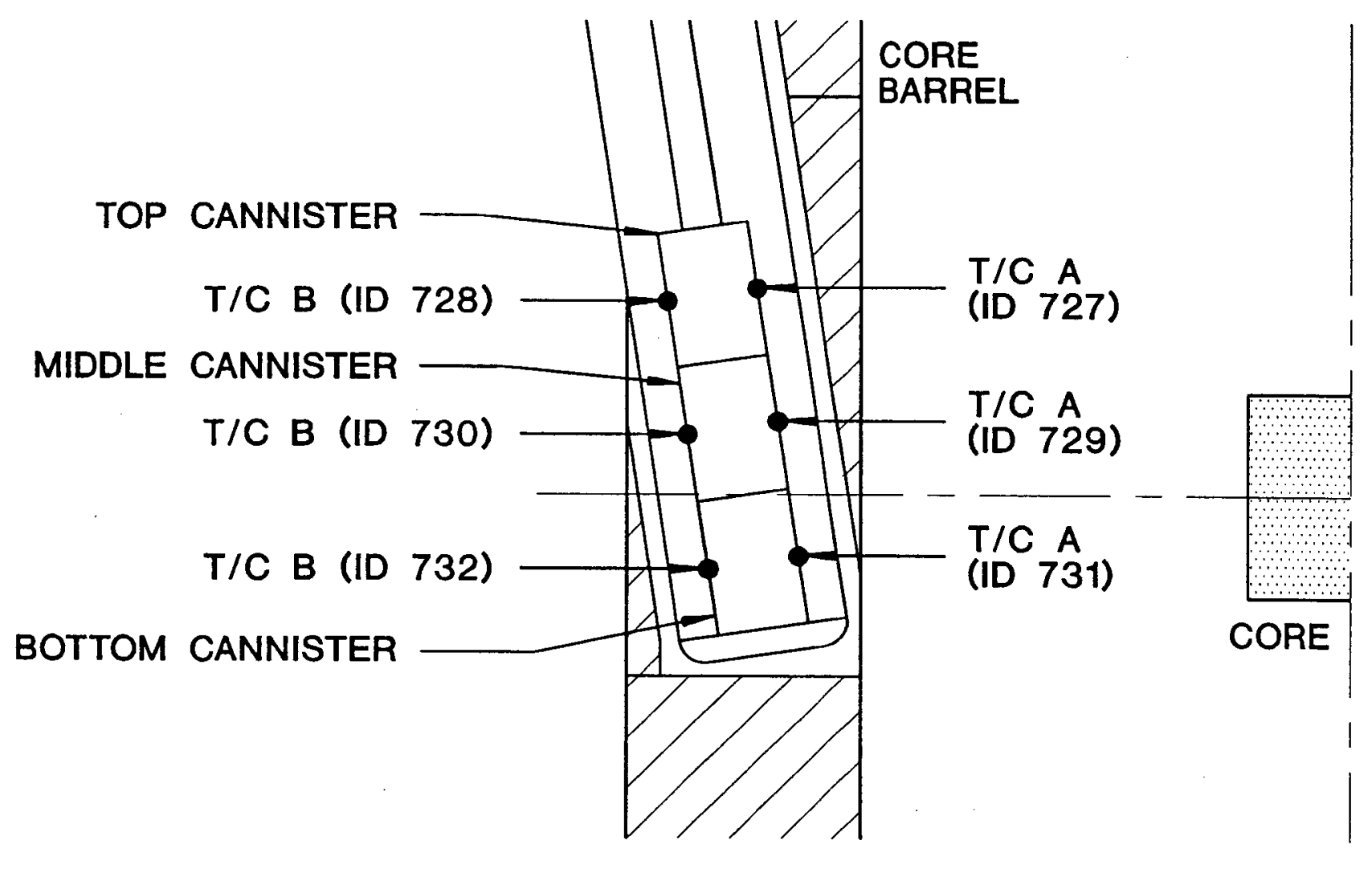

Fig. 11. Canister Thermocouple Location to Measure Canister Temperature in EBR-II 
Run No. 166A began on October 30 and was comprised of two run segments due to a loss of instrument air. The final segment concluded at $0427 \mathrm{~h}$ on December 1, 1993. Both segments of Run No. 166A provided an additional 26.34 EFPD. The total EFPD for the sample irradiation was 92.34.

\section{Assembly and Bar Sample Removal}

The NI-10 carrier assembly was removed from the $\mathrm{J} 2$ thimble on December 10 and $\mathrm{placed}$ directly into the reactor storage pit. A reading of $25 \mathrm{R}$ was taken about $2 \mathrm{ft}$ from the carrier bottom during this process. This high reading required that the samples have a long decay time in the storage pit. A combination of assembly high activity, procedure revision requirements, reactor annual maintenance shutdown, and manpower shortage caused a considerable delay for removal of the bar sample canisters.

On April 13, 1994, the lower assembly was disconnected from the upper assembly. The lower carrier was reading 40 to $70 \mathrm{R}$ between 4 to 8 in. from the surface. This required remote handling of the experiment in the "pentagon". The pentagon is a highly-shielded area of the EBR-II reactor building equipped with a remote manipulator. Additional hardware was fabricated and placed in the pentagon for the lower carrier and canister disassembly. Problems were encountered in removing two of the three canister lids. Eventually, the canisters had to be cut open with a remodeled pipe cutter. On May 16, all bar samples had been removed and placed in their individual locations in the three canisters. All the activated assembly hardware was placed in a container and placed in the storage pit. New air quality orders posed a further problem in obtaining a facility to perform the posttesting of the highly-activated samples. Eventually, the sodium components maintenance shop (SCMS) was approved for the installation of the postirradiation test equipment and new procedures for the posttest handling were developed. 


\section{E. In-reactor Environment}

\section{Temperature}

The in-reactor location of the canisters is illustrated in Fig. 11. At this location, the samples were subjected to elevated temperatures. The bottom canister being closest to the core, experienced the highest temperature and the top canister, being the farthest from the core, the lowest temperature. The temperatures of the three canisters were measured by thermocouples. Two thermocouples per canister were used as illustrated in Fig. 11. Each thermocouple was at the canister midlength with one being nearest to the core and the other diametrically opposite. The thermocouples were secured against the exterior surface of the canister. The average canister temperatures during the steady-state $100 \%$ reactor power operation were as follows:

\begin{tabular}{|c|c|}
\hline Canister & Temperature \\
\hline Top & $830^{\circ} \mathrm{F}\left(443^{\circ} \mathrm{C}\right)$ \\
\hline Middle & $997^{\circ} \mathrm{F}\left(536^{\circ} \mathrm{C}\right)$ \\
\hline Bottom & $1137^{\circ} \mathrm{F}\left(614^{\circ} \mathrm{C}\right)$ \\
\hline
\end{tabular}

Temperature histories during the in-reactor testing are given in Figs. 12 through 16. Figure 12 shows the entire temperature history for the two operating cycles. Figures 13 through 16 amplify the temperatures during the test to the reactor power and shutdown periods for the two operating cycles. The temperature of the bar samples is estimated to be somewhat higher than the thermocouple reading due to gamma heating of the canister steel and the bar sample copper. Temperatures of the bar sample copper are estimated to be 10 to $20^{\circ} \mathrm{F}\left(5.6\right.$ to $\left.11.1^{\circ} \mathrm{C}\right)$ above the thermocouple readings as a result of gamma heating. 


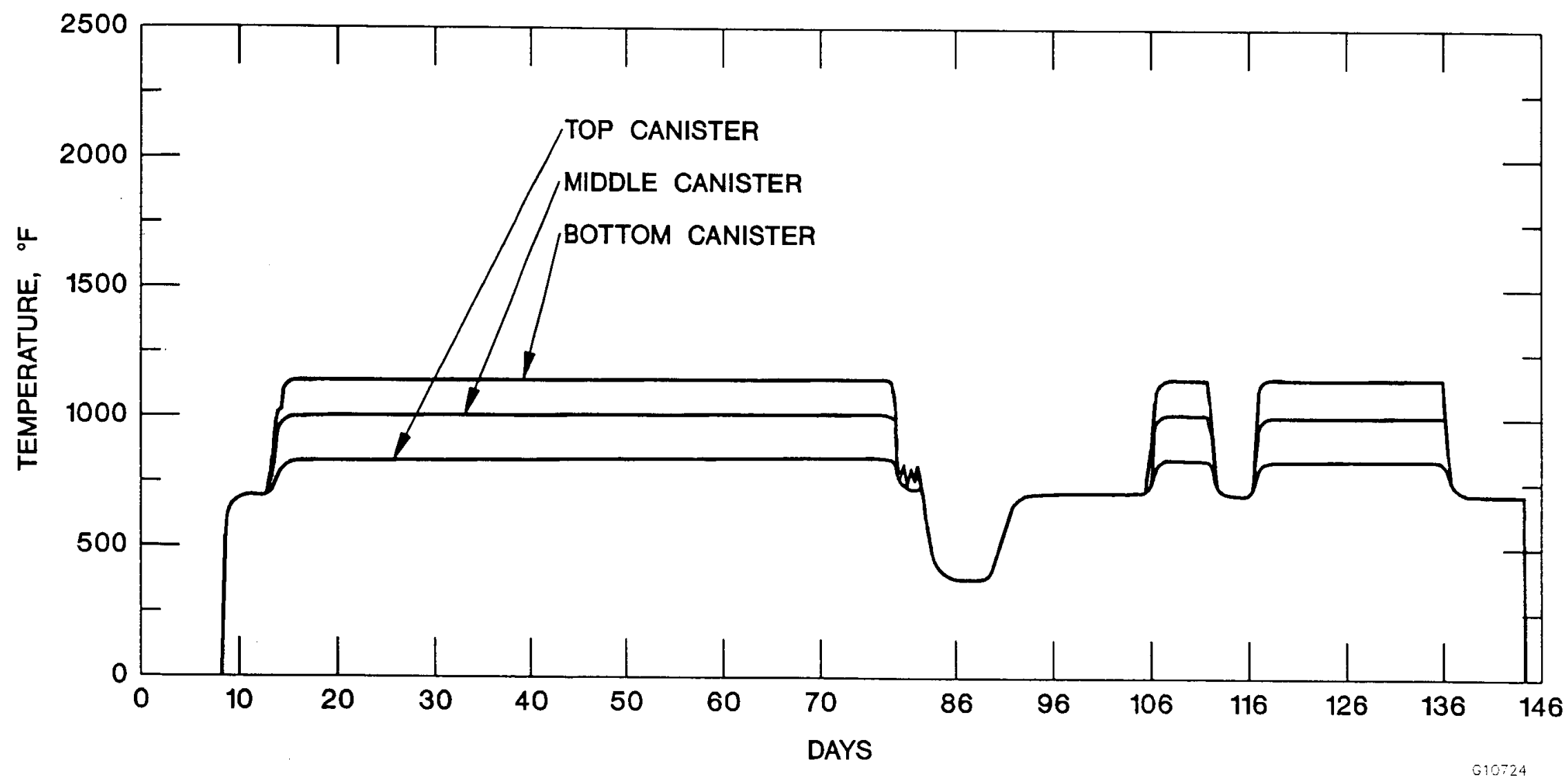

Fig. 12. Entire Temperature History for Two Operating Cycles 


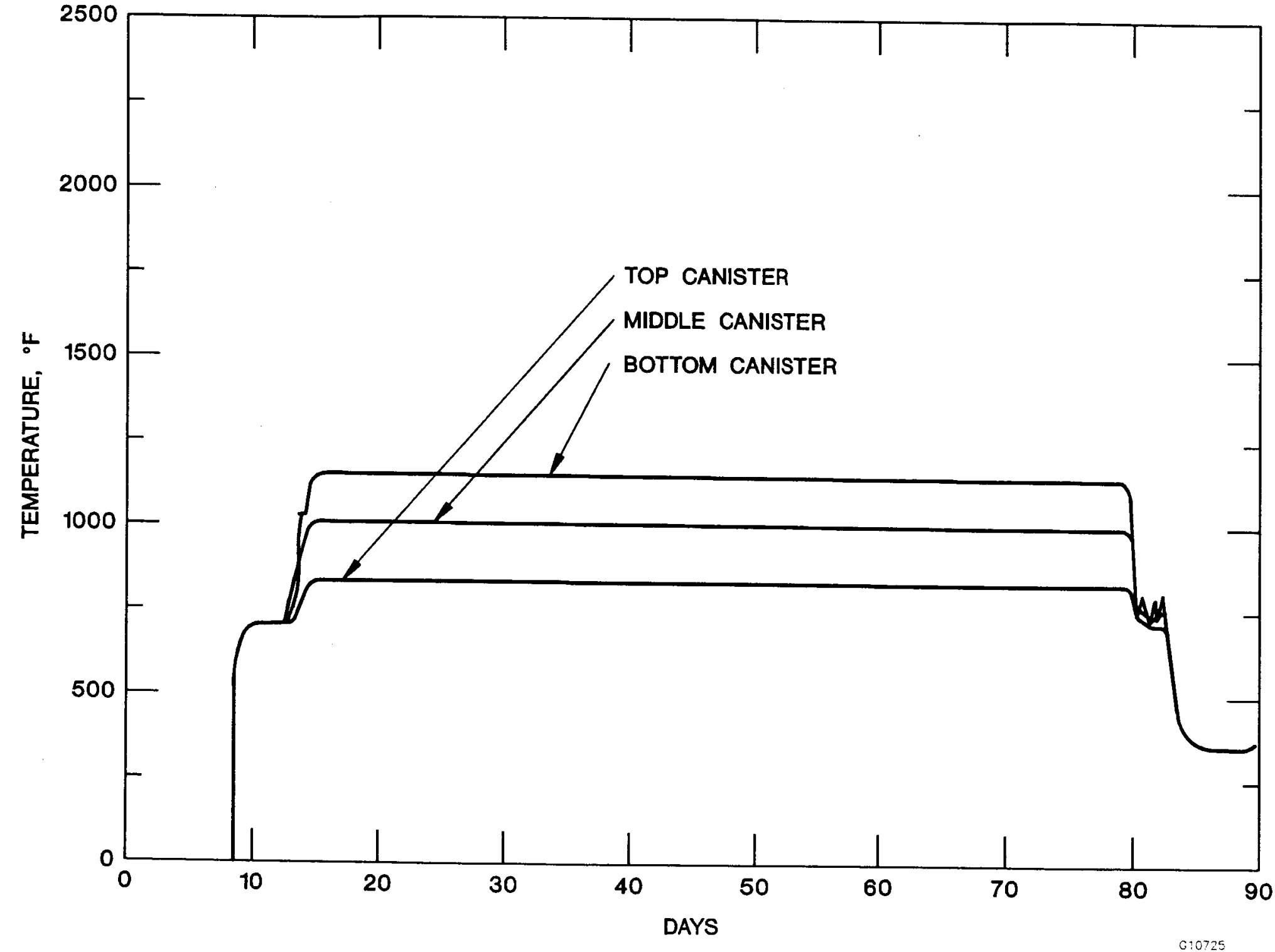

Fig. 13. Cycle 1 Temperature History Amplified 


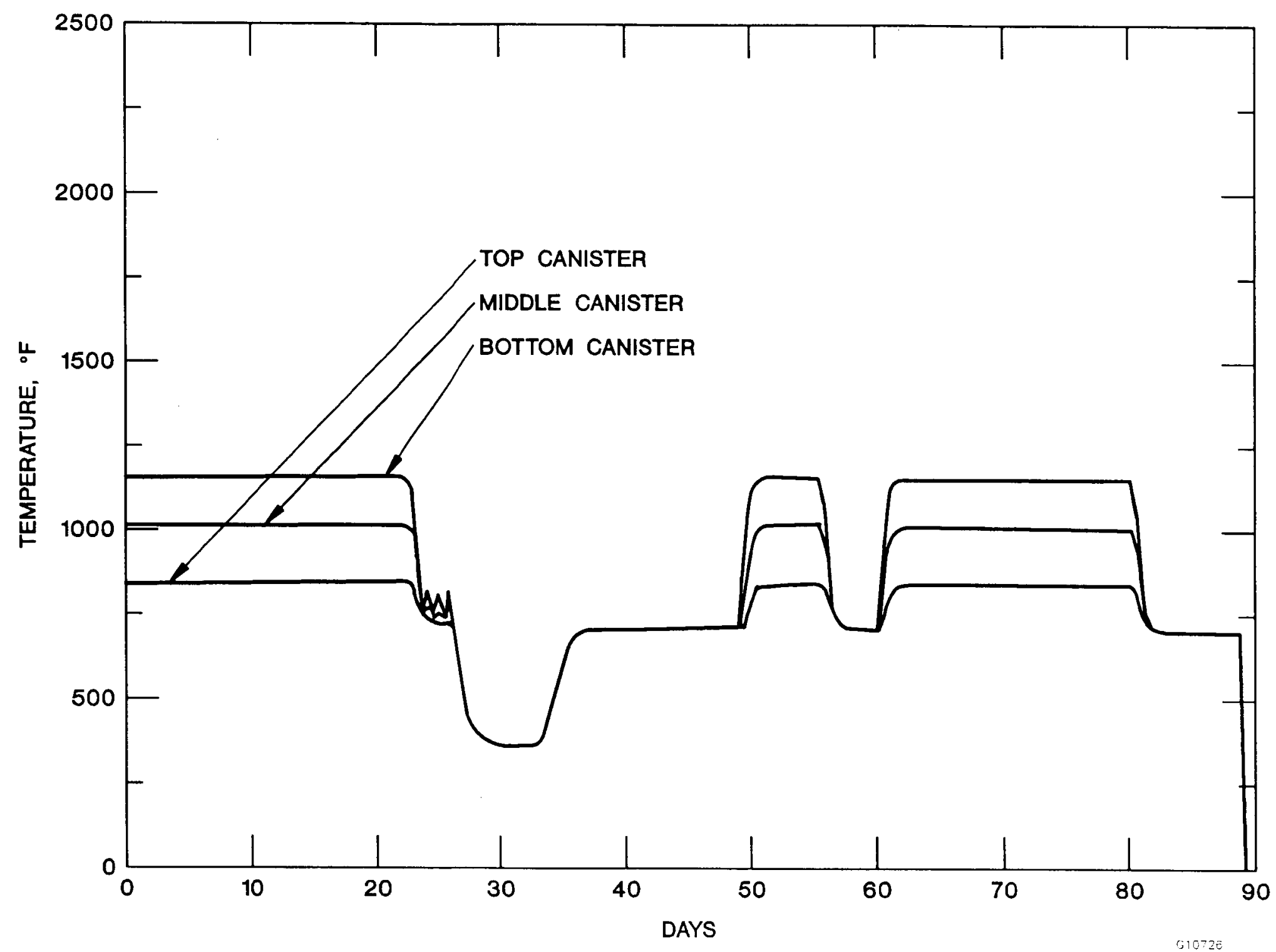

Fig. 14. Cycle 2 Temperature History Amplified 


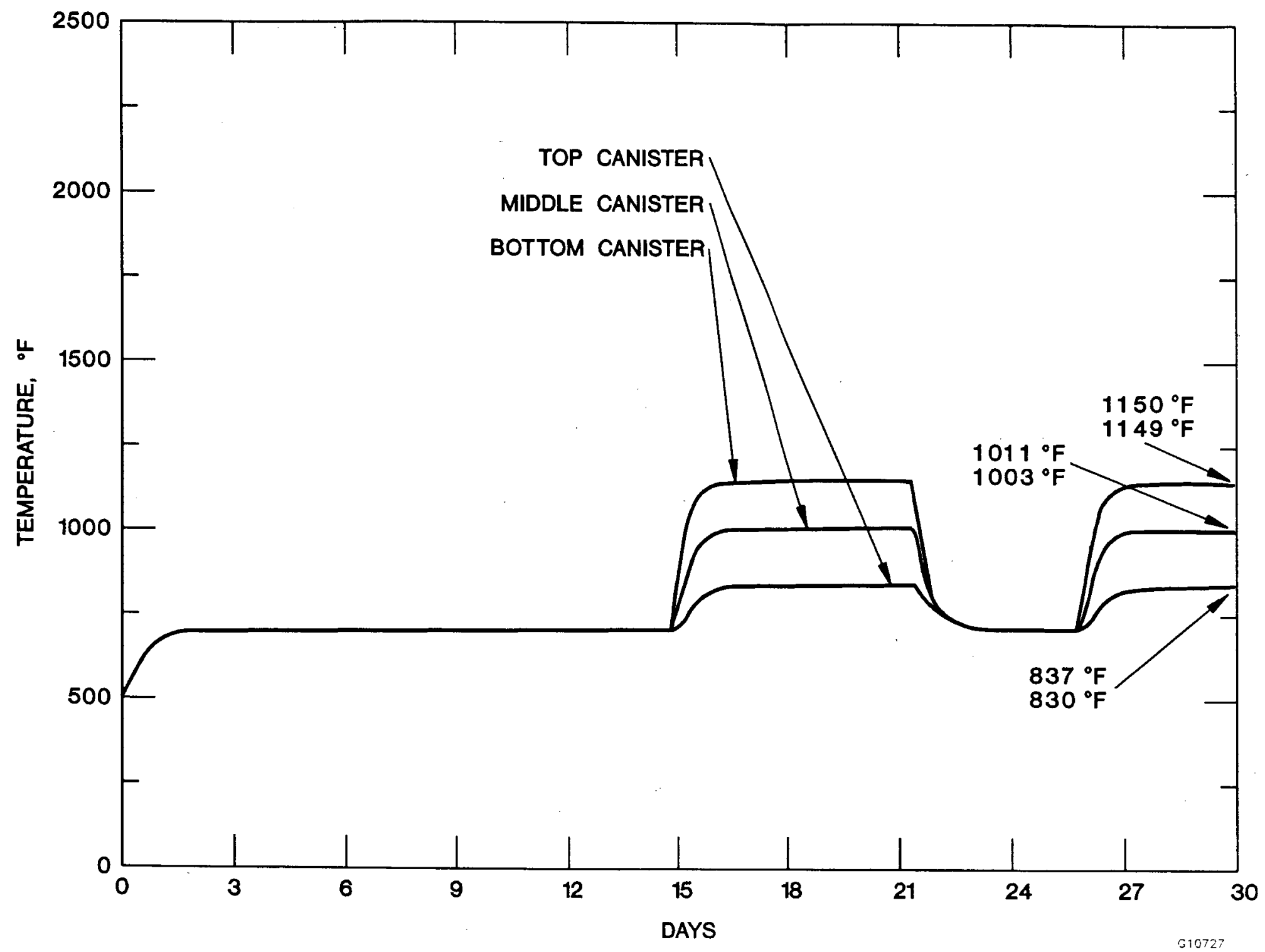

Fig. 15. Temperature History for Cycle 2 Heatup, Power Operation, Scram and Back to Power 


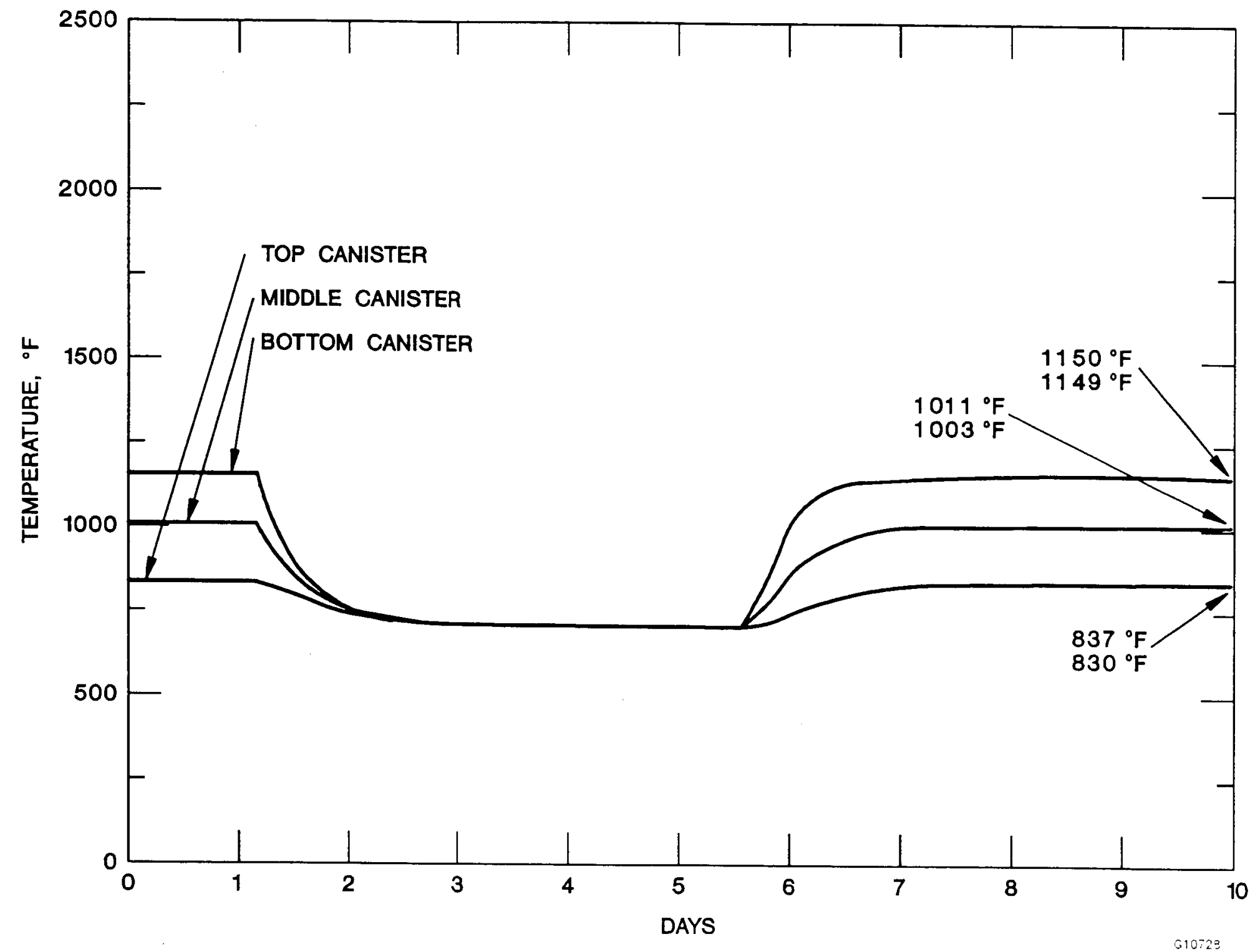

Fig. 16. Cycle 2 Scram Temperature History Amplified 


\section{Radiation}

The calculated flux level at each canister location is shown in Fig. 17. The canisters were in the reactor for two operating cycles and for the shutdown periods between the cycles. A total of 92.34 EFPD of operation and exposure to the full flux level was accumulated. The resulting fluence values are as follows:

\begin{tabular}{lcc} 
Canister & In-reactor Operation & \multicolumn{1}{c}{ Fluence } \\
Top & 92.34 EFPD & $3.0 \times 10^{17} \mathrm{n} / \mathrm{cm}^{2}$ \\
Middle & 92.34 EFPD & $2.3 \times 10^{18} \mathrm{n} / \mathrm{cm}^{2}$ \\
Bottom & 92.34 EFPD & $1.9 \times 10^{19} \mathrm{n} / \mathrm{cm}^{2}$
\end{tabular}

These values are close to the targets of $90 \mathrm{EFPD}$ and fluence of between $10^{16}$ to $10^{18} \mathrm{n} / \mathrm{cm}^{2}$. Appendix A provides the detailed analysis for flux and fluence estimate.

\section{POSTIRRADIATION TEST RESULTS}

The postirradiation testing was accomplished in two segments. Priorities and a smaller quantity of samples dictated that the Toshiba samples be tested first.

\section{A. Physical Examinations}

\section{Description}

The Toshiba samples were visually examined as they were laid out for the postirradiation testing. They had some slight discoloration, but visually the irradiation environment appeared to have had very little effect on them (see Appendix B). The insulation windings seemed to have held together very well. 


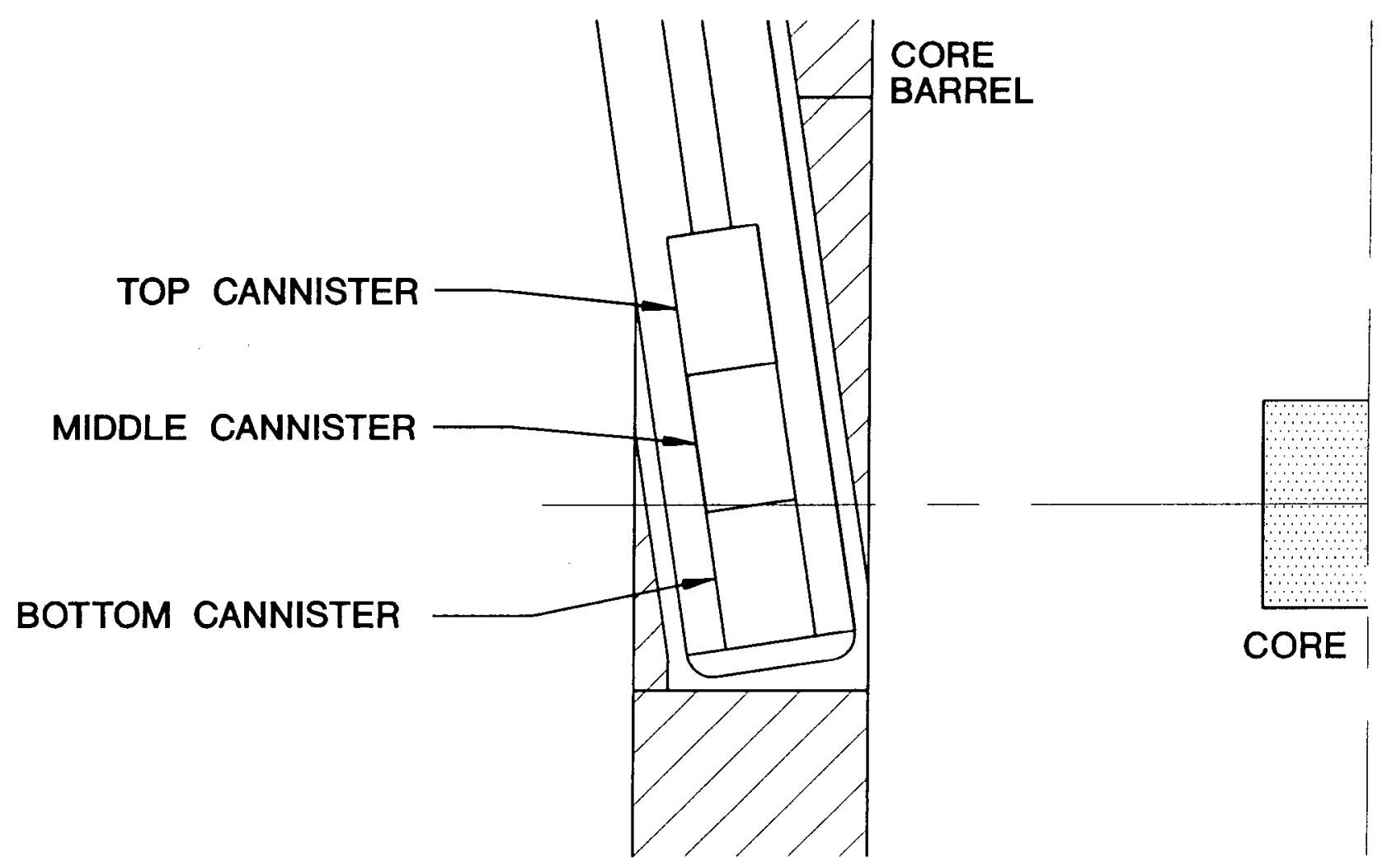

\begin{tabular}{|l|l|}
\hline CANISTER & $\begin{array}{l}\text { FLUX @ } \\
100 \% \text { POWER } \\
\mathrm{n} / \mathrm{cm}^{2}-\mathrm{s}\end{array}$ \\
\hline TOP & $\begin{array}{l}3.76 \times 10^{10} \\
\text { MIDDLE }\end{array}$ \\
$\begin{array}{l}2.89 \times 10^{11} \\
\text { BOTTOM }\end{array}$ & $2.38 \times 10^{12}$ \\
\hline
\end{tabular}

Fig. 17. Canister Radiation Response in EBR-II 
A group photograph of the six Toshiba samples was taken for reference (see Appendix B). A Mettler Model No. PM2000 balance was used for the weighing and the flat surface of a Mitutoyo digital caliper was used for the dimensional measurements.

The General Electric bar samples were also photographed and examined with the results reported in Appendix B. Figure 3 in Sect. III illustrates the locations where the bar sample dimensions were measured.

\section{Test Results}

The weights and dimensional measurements of the six Toshiba samples are listed in Table I. The weights and dimensional measurements of the 33 General Electric samples are listed in Table II.

\section{B. Electrical Testing}

\section{Description}

The electrical tests were performed on each bar sample as per the requirements of Ref. 2 . These tests were identical to those previously described for the irradiation tests in Sect. III.C.

\section{Test Results}

The results of the resistance of the Megger tests of the Toshiba samples are listed in Table III.

The results of the resistance of the Megger tests of the General Electric samples are listed in Table IV.

Leakage current readings of the Hipot tests of the Toshiba samples are found in Table $V$. 
TABLE I. Aging Test Results of the Six Toshiba Samples

\begin{tabular}{|c|c|c|c|c|c|c|}
\hline & \multirow{2}{*}{$\begin{array}{c}\text { Weight } \\
\text { Sample }\end{array}$} & \multicolumn{5}{|c|}{ Width and Thickness } \\
\cline { 3 - 7 } & $\mathrm{A}$ & $\mathrm{B}$ & $\mathrm{C}$ & $\mathrm{D}$ & $\mathrm{E}$ \\
\hline \hline Toshiba 1 & 81.7 & 0.588 & 0.507 & 0.503 & 0.508 & 0.467 \\
\hline & & 0.303 & 0.259 & 0.263 & 0.256 & 0.262 \\
\hline Toshiba 2 & 84.3 & 0.510 & 0.540 & 0.534 & 0.514 & 0.464 \\
\hline & & 0.312 & 0.278 & 0.265 & 0.280 & 0.276 \\
\hline Toshiba 3 & 84.3 & 0.567 & 0.494 & 0.504 & 0.494 & 0.487 \\
\hline & & 0.307 & 0.266 & 0.278 & 0.287 & 0.282 \\
\hline Toshiba 4 & 82.7 & 0.550 & 0.495 & 0.502 & 0.495 & 0.468 \\
\hline & & 0.329 & 0.275 & 0.265 & 0.260 & 0.262 \\
\hline Toshiba 5 & 81.7 & 0.560 & 0.489 & 0.494 & 0.501 & 0.462 \\
\hline & & 0.315 & 0.269 & 0.260 & 0.258 & 0.260 \\
\hline Toshiba 6 & 84.1 & 0.531 & 0.499 & 0.500 & 0.503 & 0.470 \\
\hline & & 0.286 & 0.268 & 0.247 & 0.269 & 0.248 \\
\hline
\end{tabular}

TABLE II. Aging Test Results of the 33 General Electric Samples

\begin{tabular}{|c|c|c|c|c|c|c|}
\hline \multirow{2}{*}{ Sample } & \multirow{2}{*}{$\begin{array}{c}\text { Weight } \\
(\mathrm{q})\end{array}$} & \multicolumn{5}{|c|}{ Width and Thickness } \\
\cline { 3 - 7 } & $\mathrm{A}$ & $\mathrm{B}$ & $\mathrm{C}$ & $\mathrm{D}$ & $\mathrm{E}$ \\
\hline $\mathrm{N} 10$ & 78.4 & 0.537 & 0.529 & 0.518 & 0.509 & 0.491 \\
\hline & & 0.333 & 0.254 & 0.247 & 0.242 & 0.295 \\
\hline $\mathrm{N} 11$ & 80.9 & 0.493 & 0.517 & 0.539 & 0.532 & 0.477 \\
\hline & & 0.244 & 0.262 & 0.266 & 0.267 & 0.245 \\
\hline $\mathrm{N} 12$ & 82.3 & 0.508 & 0.560 & 0.531 & 0.530 & 0.543 \\
\hline & & 0.283 & 0.268 & 0.266 & 0.268 & 0.279 \\
\hline $\mathrm{N} 13$ & 81.4 & 0.466 & 0.548 & 0.566 & 0.515 & 0.554 \\
\hline & & 0.247 & 0.268 & 0.271 & 0.265 & 0.310 \\
\hline $\mathrm{N} 14$ & 81.2 & 0.534 & 0.559 & 0.551 & 0.521 & 0.503 \\
\hline & & 0.294 & 0.261 & 0.264 & 0.258 & 0.284 \\
\hline
\end{tabular}


TABLE II. (Contd.)

\begin{tabular}{|c|c|c|c|c|c|c|}
\hline \multirow[b]{2}{*}{ Sample } & \multirow{2}{*}{$\begin{array}{l}\text { Weight } \\
\text { (g) }\end{array}$} & \multicolumn{5}{|c|}{ Width and Thickness Dimensions (in.) } \\
\hline & & A & B & $\mathrm{C}$ & $\underline{D}$ & $E$ \\
\hline \multirow[t]{2}{*}{ N15 } & 81.9 & 0.510 & 0.541 & 0.513 & 0.561 & 0.458 \\
\hline & & 0.305 & 0.262 & 0.266 & 0.246 & 0.282 \\
\hline \multirow[t]{2}{*}{ N16 } & 80.2 & 0.547 & 0.532 & 0.530 & 0.533 & 0.492 \\
\hline & & 0.325 & 0.261 & 0.262 & 0.241 & 0.299 \\
\hline \multirow[t]{2}{*}{ N17 } & 78.3 & 0.493 & 0.514 & 0.530 & 0.526 & 0.536 \\
\hline & & 0.282 & 0.239 & 0.250 & 0.255 & 0.330 \\
\hline N18 & $N / A$ & & & & & \\
\hline N19 & $N / A$ & & & & & \\
\hline \multirow[t]{2}{*}{$2 \mathrm{~A}$} & 84.2 & 0.498 & 0.550 & 0.551 & 0.549 & 0.565 \\
\hline & & 0.283 & 0.363 & 0.371 & 0.369 & 0.303 \\
\hline \multirow[t]{2}{*}{$3 A$} & 88.2 & 0.569 & 0.572 & 0.555 & 0.578 & 0.523 \\
\hline & & 0.331 & 0.445 & 0.423 & 0.442 & 0.319 \\
\hline \multirow[t]{2}{*}{ G1 } & 86.2 & 0.562 & 0.550 & 0.538 & 0.546 & 0.514 \\
\hline & & 0.340 & 0.350 & 0.334 & 0.345 & 0.303 \\
\hline \multirow[t]{2}{*}{ G2 } & 86.3 & 0.551 & 0.549 & 0.545 & 0.553 & 0.508 \\
\hline & & 0.330 & 0.358 & 0.339 & 0.351 & 0.297 \\
\hline \multirow[t]{2}{*}{ G3 } & 86.3 & 0.528 & 0.538 & 0.544 & 0.526 & 0.507 \\
\hline & & 0.333 & 0.360 & 0.348 & 0.330 & 0.290 \\
\hline \multirow[t]{2}{*}{ G4 } & 80.2 & 0.542 & 0.547 & 0.544 & 0.555 & 0.512 \\
\hline & & 0.316 & 0.345 & 0.338 & 0.356 & 0.297 \\
\hline \multirow[t]{2}{*}{ G5 } & 89.4 & 0.568 & 0.558 & 0.529 & 0.534 & 0.530 \\
\hline & & 0.375 & 0.357 & 0.343 & 0.334 & 0.312 \\
\hline \multirow[t]{2}{*}{ G6 } & 90.8 & 0.565 & 0.564 & 0.553 & 0.566 & 0.528 \\
\hline & & 0.354 & 0.382 & 0.366 & 0.368 & 0.317 \\
\hline \multirow[t]{2}{*}{ G7 } & 87.9 & 0.590 & 0.562 & 0.548 & 0.548 & 0.514 \\
\hline & & 0.360 & 0.364 & 0.356 & 0.365 & 0.308 \\
\hline
\end{tabular}


TABLE II. (Contd.)

\begin{tabular}{|c|c|c|c|c|c|c|}
\hline \multirow[b]{2}{*}{ Sample } & \multirow{2}{*}{$\begin{array}{l}\text { Weight } \\
\text { (g) }\end{array}$} & \multicolumn{5}{|c|}{ Width and Thickness Dimensions (in.) } \\
\hline & & A & $\mathrm{B}$ & $\mathrm{C}$ & D & E \\
\hline \multirow[t]{2}{*}{ G8 } & 89.5 & 0.560 & 0.556 & 0.558 & 0.564 & 0.549 \\
\hline & & 0.384 & 0.368 & 0.364 & 0.371 & 0.329 \\
\hline \multirow[t]{2}{*}{ G9 } & 87.4 & 0.579 & 0.554 & 0.539 & 0.525 & 0.514 \\
\hline & & 0.357 & 0.356 & 0.338 & 0.349 & 0.297 \\
\hline \multirow[t]{2}{*}{ G10 } & 88.8 & 0.572 & 0.554 & 0.545 & 0.549 & 0.523 \\
\hline & & 0.392 & 0.375 & 0.348 & 0.362 & 0.289 \\
\hline \multirow[t]{2}{*}{ G11 } & 89.5 & 0.589 & 0.585 & 0.552 & 0.549 & 0.538 \\
\hline & & 0.399 & 0.395 & 0.375 & 0.373 & 0.310 \\
\hline G12 & $N / A$ & & & & & \\
\hline G13 & $N / A$ & & & & & \\
\hline \multirow[t]{2}{*}{ G14 } & 85.3 & 0.523 & 0.542 & 0.551 & 0.539 & 0.508 \\
\hline & & 0.326 & 0.337 & 0.357 & 0.365 & 0.298 \\
\hline G15 & $\mathrm{N} / \mathrm{A}$ & & & & & \\
\hline G16 & $N / A$ & & & & & \\
\hline \multirow[t]{2}{*}{ G21 } & 85.0 & 0.588 & 0.585 & 0.619 & 0.605 & 0.546 \\
\hline & & 0.326 & 0.392 & 0.386 & 0.383 & 0.360 \\
\hline \multirow[t]{2}{*}{ G22 } & 84.5 & 0.631 & 0.593 & 0.589 & 0.601 & 0.549 \\
\hline & & 0.408 & 0.398 & 0.377 & 0.378 & 0.347 \\
\hline \multirow[t]{2}{*}{ G26 } & 84.9 & 0.565 & 0.606 & 0.611 & 0.616 & 0.568 \\
\hline & & 0.352 & 0.374 & 0.368 & 0.371 & 0.353 \\
\hline G32 & $N / A$ & & & & & \\
\hline \multirow[t]{2}{*}{ G33 } & 80.5 & 0.540 & 0.550 & 0.542 & 0.558 & 0.506 \\
\hline & & 0.300 & 0.319 & 0.311 & 0.339 & 0.293 \\
\hline
\end{tabular}


TABLE III. Pre-and Postaging Megger Electrical Testing of Toshiba Samples

\begin{tabular}{|c|c|c|}
\hline Sample & $\begin{array}{c}\text { Preaging } \\
\text { Megger Test } \\
\text { GR }\end{array}$ & $\begin{array}{c}\text { Postaging } \\
\text { Megger Test } \\
\text { G } \Omega\end{array}$ \\
\hline \hline Toshiba 1 & $>100$ & $>100$ \\
\hline Toshiba 2 & $>100$ & $>100$ \\
\hline Toshiba 3 & 80 & 80 \\
\hline Toshiba 4 & $>100$ & $>100$ \\
\hline Toshiba 5 & $>100$ & $>100$ \\
\hline Toshiba 6 & $>100$ & $>100$ \\
\hline
\end{tabular}

TABLE IV. Pre-and Postaging Megger Electrical Testing of General Electric Samples

\begin{tabular}{|c|c|c|}
\hline Sample & $\begin{array}{c}\text { Preaging } \\
\text { Megger Test } \\
\text { G } \Omega \\
\end{array}$ & $\begin{array}{c}\text { Postaging } \\
\text { Megger Test } \\
\text { G } \Omega\end{array}$ \\
\hline $\mathrm{N} 10$ & $>100$ & $>100$ \\
\hline $\mathrm{N} 11$ & $>100$ & $>100$ \\
\hline $\mathrm{N} 12$ & $>100$ & $\mathrm{~N} / \mathrm{A}$ \\
\hline $\mathrm{N} 13$ & $>100$ & $>100$ \\
\hline $\mathrm{N} 14$ & $>100$ & 60 \\
\hline N15 & $>100$ & $>100$ \\
\hline $\mathrm{N} 16$ & $>100$ & $N / A$ \\
\hline $\mathrm{N} 17$ & $>100$ & $>100$ \\
\hline N18 & $N / A$ & $N / A$ \\
\hline $\mathrm{N} 19$ & $\mathrm{~N} / \mathrm{A}$ & $N / A$ \\
\hline $2 A$ & $>100$ & $>100$ \\
\hline $3 A$ & $>100$ & $N / A$ \\
\hline G1 & $>100$ & $>100$ \\
\hline G2 & $>100$ & $>100$ \\
\hline G3 & $>100$ & $>100$ \\
\hline
\end{tabular}


TABLE IV. (Contd.)

\begin{tabular}{|c|c|c|}
\hline Sample & $\begin{array}{c}\text { Preaging } \\
\text { Megger Test } \\
\text { GR } \\
\end{array}$ & $\begin{array}{c}\text { Postaging } \\
\text { Megger Test } \\
G \Omega \\
\end{array}$ \\
\hline G4 & $>100$ & $N / A$ \\
\hline G5 & $>100$ & $N / A$ \\
\hline G6 & $>100$ & $>100$ \\
\hline G7 & $>100$ & $>100$ \\
\hline G8 & $>100$ & $>100$ \\
\hline G9 & $>100$ & $\mathrm{~N} / \mathrm{A}$ \\
\hline G10 & $>100$ & $N / A$ \\
\hline G11 & $>100$ & $N / A$ \\
\hline G12 & $\mathrm{N} / \mathrm{A}$ & $\mathrm{N} / \mathrm{A}$ \\
\hline G13 & $N / A$ & $\mathrm{~N} / \mathrm{A}$ \\
\hline G14 & $>100$ & $>100$ \\
\hline G15 & $\mathrm{N} / \mathrm{A}$ & $N / A$ \\
\hline G16 & $N / A$ & $N / A$ \\
\hline G21 & $>100$ & $>100$ \\
\hline G22 & $>100$ & $>100$ \\
\hline G26 & $>100$ & $>100$ \\
\hline G32 & $N / A$ & $\mathrm{~N} / \mathrm{A}$ \\
\hline G33 & $>100$ & $>100$ \\
\hline
\end{tabular}


TABLE V. Pre-and Postaging Hipot Electrical Testing of Toshiba Samples

\begin{tabular}{|c|c|c|}
\hline Sample & $\begin{array}{c}\text { Preaging } \\
\text { Hipot Test } \\
\mathrm{mA}\end{array}$ & $\begin{array}{c}\text { Postaging } \\
\text { Hipot Test } \\
\mathrm{mA}\end{array}$ \\
\hline \hline Toshiba 1 & 0.244 & 0.187 \\
\hline Toshiba 2 & 0.204 & 0.186 \\
\hline Toshiba 3 & $0.310^{\mathrm{a}}$ & $0.192^{\mathrm{b}}$ \\
\hline Toshiba 4 & 0.198 & 0.193 \\
\hline Toshiba 5 & 0.217 & 0.186 \\
\hline Toshiba 6 & 0.216 & 0.189 \\
\hline
\end{tabular}

${ }^{9}$ Read $0.310 \mathrm{~mA}$, then arced to 0 indicating failure.

Beading $0.192 \mathrm{~mA}$, audible arcing, power shut off.

Leakage current readings of the Hipot tests of the General Electric samples are found in Table VI.

\section{Accelerated Age Testing}

1. Description

The aging test of the Toshiba samples was conducted at approximately $1345^{\circ} \mathrm{F}$ and $600 \mathrm{VAC}$ for $503 \mathrm{~h}$.

The aging test of the General Electric samples was conducted at approximately $1345^{\circ} \mathrm{F}$ and $1500 \mathrm{VAC}$ for $355 \mathrm{~h}$.

\section{Test Results}

Data taken during the aging tests for the Toshiba samples are shown in Table VII.

Data taken during the aging tests for the Toshiba samples are shown in Table VIII. 
TABLE VI. Pre-and Postaging Hipot Electrical Testing of General Electric Samples

\begin{tabular}{|c|c|c|}
\hline Sample & $\begin{array}{c}\text { Preaging } \\
\text { Hipot Test } \\
\text { mA }\end{array}$ & $\begin{array}{c}\text { Postaging } \\
\text { Hipot Test } \\
\mathrm{mA}\end{array}$ \\
\hline $\mathrm{N} 10$ & $2600 \mathrm{V*}$ & $2600 \mathrm{~V}$ \\
\hline $\mathrm{N} 11$ & $2800 \mathrm{V*}$ & $2600 \mathrm{V*}$ \\
\hline $\mathrm{N} 12$ & $2600 \mathrm{V*}$ & $N / A$ \\
\hline $\mathrm{N} 13$ & $1800 V *$ & $2200 \mathrm{V*}$ \\
\hline $\mathrm{N} 14$ & $1700 \mathrm{V*}$ & $1200 \mathrm{V*}$ \\
\hline N15 & $2400 \mathrm{V*}$ & $2400 \mathrm{V*}$ \\
\hline $\mathrm{N} 16$ & 0.200 & $N / A$ \\
\hline $\mathrm{N} 17$ & $2200 \mathrm{V*}$ & $1400 \mathrm{V*}$ \\
\hline $\mathrm{N} 18$ & $1900 V \star$ & $N / A$ \\
\hline $\mathrm{N} 19$ & $2400 V *$ & $N / A$ \\
\hline $2 \mathrm{~A}$ & 0.196 & 0.184 \\
\hline $3 A$ & 0.191 & $N / A$ \\
\hline G1 & 0.187 & 0.211 \\
\hline G2 & 0.181 & 0.180 \\
\hline G3 & 0.189 & 0.181 \\
\hline G4 & 0.182 & $N / A$ \\
\hline G5 & $2600 \mathrm{V*}$ & $N / A$ \\
\hline G6 & 0.200 & 0.189 \\
\hline G7 & 0.207 & 0.196 \\
\hline G8 & 0.201 & 0.184 \\
\hline G9 & 0.197 & $\mathrm{~N} / \mathrm{A}$ \\
\hline G10 & 0.193 & N/A \\
\hline G11 & 0.197 & N/A \\
\hline G12 & 0.183 & $\mathrm{~N} / \mathrm{A}$ \\
\hline G13 & 0.181 & $\mathrm{~N} / \mathrm{A}$ \\
\hline G14 & 0.174 & 0.180 \\
\hline G15 & 0.184 & $N / A$ \\
\hline
\end{tabular}


TABLE VI. (Contd.)

\begin{tabular}{|c|c|c|}
\hline Sample & $\begin{array}{c}\text { Preaging } \\
\text { Hipot Test } \\
\mathrm{mA}\end{array}$ & $\begin{array}{c}\text { Postaging } \\
\text { Hipot Test } \\
\mathrm{mA}\end{array}$ \\
\hline \hline $\mathrm{G} 16$ & 0.192 & $\mathrm{~N} / \mathrm{A}$ \\
\hline $\mathrm{G} 21$ & 0.181 & 0.174 \\
\hline $\mathrm{G} 22$ & 0.181 & 0.181 \\
\hline $\mathrm{G} 26$ & 0.195 & 0.191 \\
\hline G32 & 0.187 & $\mathrm{~N} / \mathrm{A}$ \\
\hline G33 & 0.184 & 0.182 \\
\hline
\end{tabular}

*Sample failed, audibly sizzling and buzzing.

Test was then done in $500 \mathrm{~V}$ increments to see if the voltage level at failure could be determined. Approximate voltage at failure is recorded in the table below.

\begin{tabular}{|c|c|c|c|c|c|c|}
\hline Sample & $500 \mathrm{~V}$ & $1000 \mathrm{~V}$ & $1500 \mathrm{~V}$ & $2000 \mathrm{~V}$ & $2500 \mathrm{~V}$ & Failure \\
\hline \hline \multicolumn{7}{|c|}{ Preaging } \\
\hline $\mathrm{N} 10^{\mathrm{a}}$ & 0.027 & 0.054 & 0.084 & 0.116 & 0.146 & $X-2600 \mathrm{~V}$ \\
\hline $\mathrm{N} 11^{\mathrm{a}}$ & 0.057 & 0.089 & 0.115 & 0.145 & 0.171 & 0.204 \\
\hline $\mathrm{G}^{\mathrm{b}}$ & 0.058 & 0.085 & 0.115 & 0.146 & 0.176 & 0.206 \\
\hline $\mathrm{N} 12^{\mathrm{b}}$ & 0.054 & 0.085 & 0.115 & 0.141 & 0.169 & $X-2600 \mathrm{~V}$ \\
\hline $3 \mathrm{~A}$ & 0.056 & 0.088 & 0.117 & 0.144 & 0.177 & $X \sim 2600 \mathrm{~V}$ \\
\hline $\mathrm{N} 13$ & 0.052 & 0.074 & 0.116 & $X$ & $X$ & $X-1800 \mathrm{~V}$ \\
\hline $\mathrm{N} 14$ & 0.053 & 0.086 & 0.113 & $X$ & $X$ & $X-1700 \mathrm{~V}$ \\
\hline $\mathrm{N} 15$ & 0.051 & 0.086 & 0.116 & 0.151 & $X$ & $X-2400 \mathrm{~V}$ \\
\hline $\mathrm{N} 17$ & 0.027 & 0.059 & 0.091 & 0.123 & $X$ & $X-2000 \mathrm{~V}$ \\
\hline $\mathrm{N} 18$ & 0.027 & 0.064 & 0.102 & $X$ & $X$ & $X-1900 \mathrm{~V}$ \\
\hline $\mathrm{N} 19$ & 0.033 & 0.064 & 0.099 & 0.134 & $X$ & $X-2400 \mathrm{~V}$ \\
\hline & & & \multicolumn{7}{|c|}{ Postaging } \\
\hline $\mathrm{N} 10$ & 0.025 & 0.053 & 0.087 & 0.121 & 0.146 & $X-2600 \mathrm{~V}$ \\
\hline $\mathrm{N} 11$ & 0.052 & 0.088 & 0.111 & 0.122 & 0.150 & $X-2600 \mathrm{~V}$ \\
\hline $\mathrm{N} 13$ & 0.031 & 0.061 & 0.097 & 0.139 & $X$ & $X \sim 2200 \mathrm{~V}$ \\
\hline
\end{tabular}


TABLE (Contd.)

\begin{tabular}{|c|c|c|c|c|c|c|}
\hline Sample & $500 \mathrm{~V}$ & $1000 \mathrm{~V}$ & $1500 \mathrm{~V}$ & $2000 \mathrm{~V}$ & $2500 \mathrm{~V}$ & Failure \\
\hline \hline $\mathrm{N} 14$ & 0.030 & 0.064 & $\mathrm{X}$ & $\mathrm{X}$ & $\mathrm{X}$ & $\mathrm{X} \sim 1200 \mathrm{~V}$ \\
\hline $\mathrm{N} 15$ & 0.038 & 0.064 & 0.102 & 0.139 & $\mathrm{X}$ & $\mathrm{X} \sim 2400 \mathrm{~V}$ \\
\hline $\mathrm{N} 17$ & 0.028 & 0.058 & $\mathrm{X}$ & $\mathrm{X}$ & $\mathrm{X}$ & $\mathrm{X} \sim 1400 \mathrm{~V}$ \\
\hline
\end{tabular}

anly failed sample from first canister checked at $500 \mathrm{~V}$ increments at the time.

${ }^{b}$ Rechecked with second canister of samples at a later date.

TABLE VII. Posttest Accelerated Aging Testing of the Toshiba Samples

\begin{tabular}{|c|c|c|c|c|c|c|}
\hline \multirow[b]{2}{*}{$\begin{array}{c}\text { Elapsed } \\
\text { Time } \\
\text { (h) }\end{array}$} & \multirow[b]{2}{*}{$\begin{array}{c}\text { Applied } \\
\text { Voltage } \\
\text { (V) }\end{array}$} & \multirow[b]{2}{*}{$\begin{array}{c}\text { Temp } \\
\left({ }^{\circ} \mathrm{F}\right)\end{array}$} & \multicolumn{4}{|c|}{ Leakage Current in $\mathrm{mA}$} \\
\hline & & & $\begin{array}{c}\text { Sample } \\
1\end{array}$ & $\begin{array}{l}\text { Sample } \\
2\end{array}$ & $\begin{array}{c}\text { Sample } \\
4\end{array}$ & $\begin{array}{c}\text { Sample } \\
5\end{array}$ \\
\hline 0 & 594 & 1343 & 0.670 & 0.609 & 0.640 & 0.751 \\
\hline 17 & 610 & 1347 & 0.627 & 0.638 & 0.707 & 0.726 \\
\hline 92 & 605 & 1346 & 0.697 & 0.668 & 0.635 & 0.704 \\
\hline 114 & 604 & 1351 & 0.646 & 0.675 & 0.473 & 0.669 \\
\hline 138 & 598 & 1349 & 0.603 & 0.698 & 0.400 & 0.624 \\
\hline 187 & 601 & 1353 & 0.501 & 0.719 & 0.374 & 0.462 \\
\hline 263 & 594 & 1348 & 0.452 & 0.709 & 0.329 & 0.450 \\
\hline 282 & 603 & 1345 & 0.448 & 0.738 & 0.352 & 0.475 \\
\hline 306 & 605 & 1353 & 0.426 & 0.723 & 0.364 & 0.490 \\
\hline 330 & 605 & 1346 & 0.410 & 0.713 & 0.371 & 0.485 \\
\hline 354 & 600 & 1344 & 0.388 & 0.687 & 0.370 & 0.482 \\
\hline 427 & 593 & 1345 & 0.368 & 0.680 & 0.358 & 0.459 \\
\hline 450 & 608 & 1353 & 0.365 & 0.668 & 0.374 & 0.477 \\
\hline 475 & 606 & 1345 & 0.366 & 0.671 & 0.372 & 0.525 \\
\hline 503 & 605 & 1344 & 0.361 & 0.668 & 0.363 & 0.481 \\
\hline
\end{tabular}


TABLE VIII. Posttest Accelerated Aging Testing of the General Electric Samples

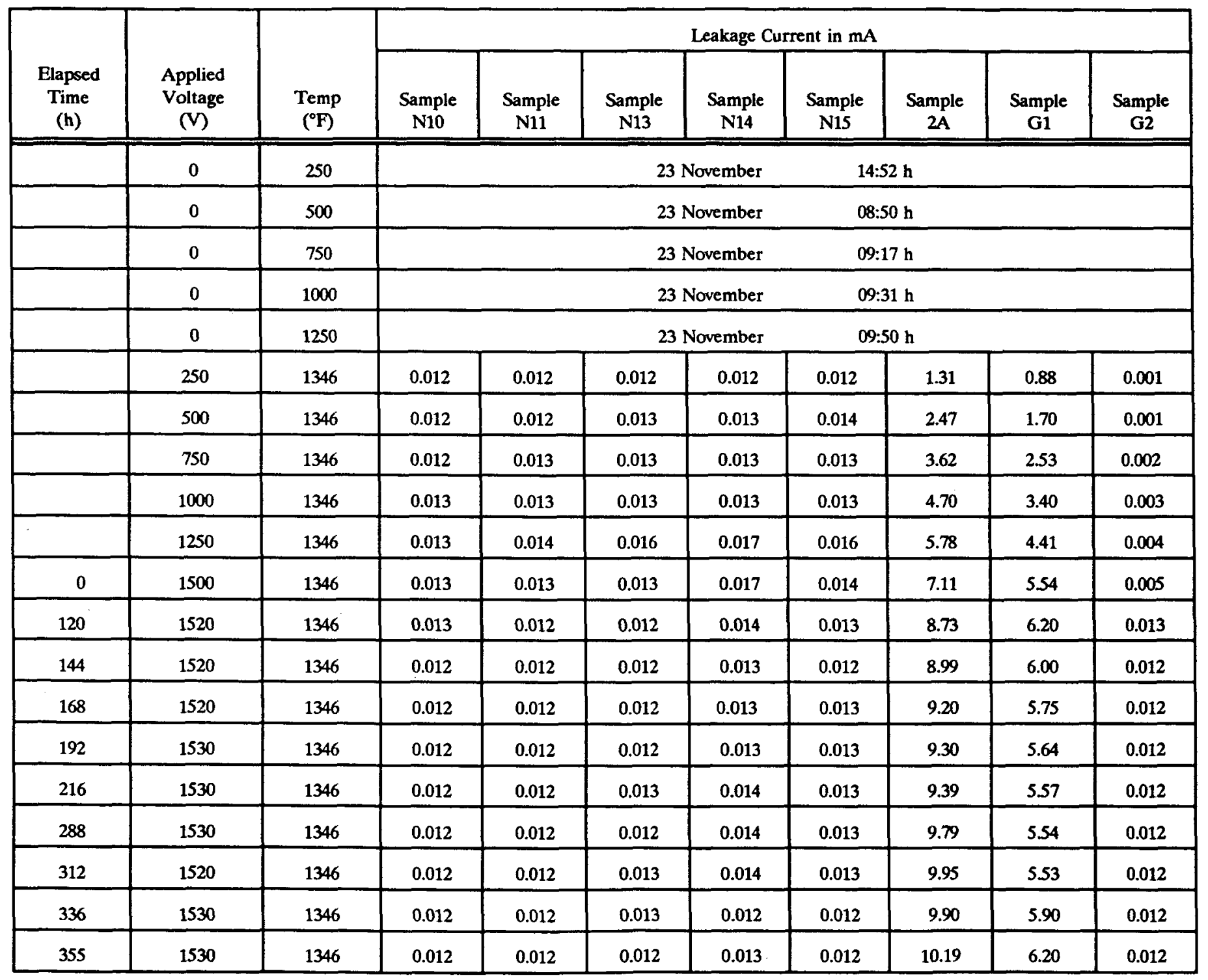


TABLE VIII. (Contd.)

\begin{tabular}{|c|c|c|c|c|c|c|c|c|c|}
\hline \multirow[b]{2}{*}{$\begin{array}{c}\text { Elapsed } \\
\text { Time } \\
\text { (h) } \\
\end{array}$} & \multirow[b]{2}{*}{$\begin{array}{c}\text { Applied } \\
\text { Voltage } \\
\text { (V) }\end{array}$} & \multirow[b]{2}{*}{ Temp ${ }^{\circ} \mathbf{F}$} & \multicolumn{7}{|c|}{ Leakage Current in $\mathrm{mA}$} \\
\hline & & & $\begin{array}{c}\text { Sample } \\
\text { G3 }\end{array}$ & $\begin{array}{c}\text { Sample } \\
\text { G6 }\end{array}$ & $\begin{array}{c}\text { Sample } \\
\text { G7 }\end{array}$ & $\begin{array}{c}\text { Sample } \\
\text { G8 }\end{array}$ & $\begin{array}{c}\text { Sample } \\
\text { G21 }\end{array}$ & $\begin{array}{c}\text { Sample } \\
\text { G22 }\end{array}$ & $\begin{array}{c}\text { Sample } \\
\text { G26 }\end{array}$ \\
\hline & 0 & 250 & \multicolumn{4}{|c|}{22 November } & \multicolumn{3}{|l|}{$14: 52 \mathrm{~h}$} \\
\hline & 0 & 500 & \multicolumn{4}{|c|}{23 November } & \multicolumn{3}{|l|}{$08: 50 \mathrm{~h}$} \\
\hline & 0 & 750 & \multicolumn{4}{|c|}{23 November } & \multicolumn{3}{|l|}{ 09:17 h } \\
\hline & 0 & 1000 & \multicolumn{4}{|c|}{23 November } & \multicolumn{3}{|l|}{$09: 31 \mathrm{~h}$} \\
\hline & 0 & 1250 & \multicolumn{4}{|c|}{23 November } & \multicolumn{2}{|l|}{ 09:50 h } & \\
\hline & 250 & 1346 & 0.96 & 0.001 & 0.012 & 0.001 & 7.76 & 0.000 & 0.001 \\
\hline & 500 & 1346 & 1.82 & 0.002 & 0.013 & 0.003 & 15.64 & 0.002 & 0.002 \\
\hline & 750 & 1346 & 2.77 & 0.003 & 0.012 & 0.004 & 23.9 & 0.003 & 0.003 \\
\hline & 1000 & 1346 & 3.73 & 0.005 & 0.013 & 0.005 & 32.2 & 0.004 & 0.004 \\
\hline & 1250 & 1346 & 4.78 & 0.006 & 0.016 & 0.006 & 41.7 & 0.005 & 0.006 \\
\hline 0 & 1500 & 1346 & 6.02 & 0.013 & 0.014 & 0.014 & 53.6 & 0.006 & 0.014 \\
\hline 120 & 1520 & 1346 & 6.58 & 0.012 & 0.013 & 0.013 & 52.6 & 0.013 & 0.013 \\
\hline 144 & 1520 & 1346 & 6.40 & 0.012 & 0.012 & 0.012 & 52.5 & 0.012 & 0.012 \\
\hline 168 & 1520 & 1346 & 6.00 & 0.012 & 0.012 & 0.012 & 52.5 & 0.012 & 0.012 \\
\hline 192 & 1530 & 1346 & 6.00 & 0.012 & 0.013 & 0.013 & 52.9 & 0.012 & 0.013 \\
\hline 216 & 1530 & 1346 & 6.00 & 0.012 & 0.013 & 0.013 & 54.0 & 0.012 & 0.013 \\
\hline 288 & 1530 & 1346 & 6.01 & 0.012 & 0.012 & 0.013 & 54.2 & 0.012 & 0.013 \\
\hline 312 & 1520 & 1346 & 5.89 & 0.012 & 0.013 & 0.013 & 53.7 & 0.012 & 0.012 \\
\hline 336 & 1530 & 1346 & 6.20 & 0.012 & 0.012 & 0.012 & 54.0 & 0.012 & 0.013 \\
\hline 355 & 1530 & 1346 & 5.54 & 0.012 & 0.012 & 0.012 & 53.4 & 0.012 & 0.012 \\
\hline
\end{tabular}


TABLE VIII. (Contd.)

\begin{tabular}{|c|c|c|c|c|c|}
\hline \multirow[b]{2}{*}{$\begin{array}{l}\text { Elapsed } \\
\text { Time } \\
\text { (h) }\end{array}$} & \multirow[b]{2}{*}{$\begin{array}{c}\text { Applied } \\
\text { Voltage } \\
\text { (V) }\end{array}$} & \multirow[b]{2}{*}{$\begin{array}{c}\text { Temp } \\
\left({ }^{\circ} \mathrm{F}\right)\end{array}$} & \multicolumn{3}{|c|}{ Leakage Current in $\mathrm{mA}$} \\
\hline & & & $\begin{array}{c}\text { Sample } \\
\text { N17 }\end{array}$ & $\begin{array}{c}\text { Sample } \\
\text { G33 }\end{array}$ & $\begin{array}{c}\text { Sample } \\
\text { G14 }\end{array}$ \\
\hline & 0 & 250 & \multicolumn{3}{|c|}{16 Jan 1995} \\
\hline & 0 & 500 & \multicolumn{2}{|c|}{16 Jan 1995} & \\
\hline & 0 & 750 & \multicolumn{2}{|c|}{$16 \operatorname{Jan} 1995$} & \\
\hline & 0 & 1000 & \multicolumn{2}{|c|}{ 16 Jan 1995} & \\
\hline & $\mathbf{0}$ & 1250 & \multicolumn{2}{|c|}{$16 \operatorname{Jan} 1995$} & \\
\hline & 0 & 1346 & \multicolumn{2}{|c|}{$16 \operatorname{Jan} 1995$} & \\
\hline & 250 & 1346 & 0.007 & 0.012 & 0.012 \\
\hline & 500 & 1346 & 0.015 & 0.012 & 0.012 \\
\hline & 750 & 1346 & 0.012 & 0.012 & 0.012 \\
\hline & 1000 & 1346 & 0.012 & 0.012 & 0.012 \\
\hline & 1250 & 1346 & 0.012 & 0.012 & 0.012 \\
\hline $\mathbf{0}$ & 1500 & 1346 & 0.012 & 0.012 & 0.012 \\
\hline
\end{tabular}


TABLE VIII. (Contd.)

\begin{tabular}{|c|c|c|c|c|c|}
\hline \multirow[b]{2}{*}{$\begin{array}{l}\text { Elapsed } \\
\text { Time } \\
\text { (h) }\end{array}$} & \multirow[b]{2}{*}{$\begin{array}{c}\text { Applied } \\
\text { Voltage } \\
\text { (V) }\end{array}$} & \multirow[b]{2}{*}{$\begin{array}{l}\text { Temp } \\
\left({ }^{\circ} \mathrm{F}\right)\end{array}$} & \multicolumn{3}{|c|}{ Leakage Current in $\mathrm{mA}$} \\
\hline & & & $\begin{array}{l}\text { Sample } \\
\text { N17 }\end{array}$ & $\begin{array}{c}\text { Sample } \\
\text { G33 }\end{array}$ & $\begin{array}{c}\text { Sample } \\
\text { G14 }\end{array}$ \\
\hline 17 & 1500 & 1346 & 0.013 & 0.012 & 0.012 \\
\hline 41 & 1500 & 1346 & 0.012 & 0.012 & 0.012 \\
\hline 65 & 1500 & 1346 & 0.012 & 0.012 & 0.012 \\
\hline 89 & 1500 & 1346 & 0.011 & 0.011 & 0.011 \\
\hline 161 & 1500 & 1346 & 0.015 & 0.015 & 0.015 \\
\hline 185 & 1500 & 1346 & 0.016 & 0.016 & 0.016 \\
\hline 209 & 1500 & 1346 & 0.014 & 0.014 & 0.014 \\
\hline 233 & 1500 & 1346 & 0.013 & 0.013 & 0.013 \\
\hline 257 & 1500 & 1346 & 0.013 & 0.013 & 0.013 \\
\hline 329 & 1500 & 1346 & 0.012 & 0.011 & 0.011 \\
\hline 353 & 1500 & 1346 & 0.011 & 0.011 & 0.011 \\
\hline 355 & 1500 & 1346 & - & - & - \\
\hline
\end{tabular}




\section{TEMPERATURE TEST}

\section{A. Overal1 Description}

As part of this EM insulation bar sample irradiation program, a controlled temperature test was conducted in an oven at ANL-East. This test used a test canister (Canister No. 4) which was identical to the three canisters containing the bar samples irradiated in the J2 thimble of EBR-II. This fourth canister containing 13 bar samples was sealed with 1 atm of nitrogen in the welding glovebox. This canister was placed in an oven (Oven No. 4 at ANL-East) with the temperature history set to mimic that obtained in the highest irradiation canister (i.e., lower canister No. 3). To insure a pure nitrogen atmosphere within the canister, the glovebox was purged with pure bottled nitrogen gas three times before the canister lid was secured. Based on the results of previous test closures, a torque of $70 \mathrm{ft}-1 \mathrm{~b}$ when applied to the canister lid was sufficient to insure a leak-tight lid closure seal. A gas sample of the final glovebox (i.e., canister) atmosphere was taken for archival purposes. Before and after subjecting the bar samples to the actual oven temperature test, several physical and electrical tests and measurements were conducted on the samples. In addition, both a before and after accelerated aging test were conducted in an air oven at temperature and voltage.

Shown in Table IX are the number and type of each of the insulation bar samples that were included in the temperature test. The 13 samples included representatives from each of the five EM pump insulation types included in the irradiation program. As indicated in Table IX, the temperature test samples consisted of three Amber Mica/SECON-5 bars, three Toshiba (splitting mica)/silicon binder bars, three Nextel 440 (ceramic tape)/boron nitride binder bars, two white mica/SECON-5 binder bars, and two amber mica/boron nitride binder bars. For a detailed description of these bar samples, including the chemical composition of the various constituents, Ref. 1 should be consulted. 
TABLE IX. Temperature Test Bar Sample Identification

\begin{tabular}{|c|c|}
\hline Bar Sample Type & Insulation Bar Sample Designation \\
\hline \hline Amber/SEC & G17, G18, G19 \\
\hline Toshiba/Si & $9,10,11$ \\
\hline $440 / B N$ & N20, N21, N22 \\
\hline White/SEC & G37, G38 \\
\hline Amber/BN & 3 A-92, 4A \\
\hline
\end{tabular}

Key

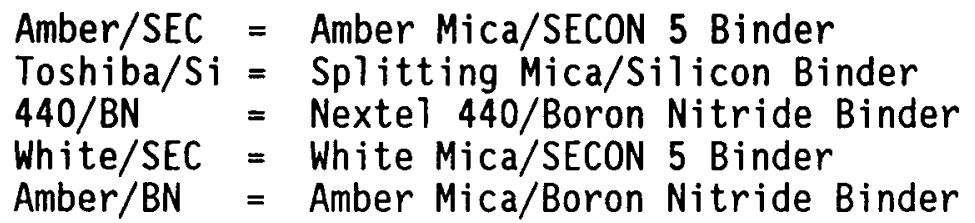

The various examinations, test phases and their sequence for each of the 13 bar samples included in the temperature test are provided in Table $X$. As Table $X$ indicates, the temperature test consisted of essentially nine phases or steps beginning with an initial sample examination and concluding with a final examination of the samples. Also, it should be noted that before and after the actual temperature test an accelerated aging test and several Megger and Hipot electrical measurements were made on some of the samples. As per the test plan of Ref. 2 and subsequent instructions based on the needs of the substituted or replacement bar samples (see Ref. 1), all of the samples did not undergo the complete test sequence. The replacement Nextel 440/BN and Amber/BN bar samples were uncured and therefore were not subjected to the set of initial examinations and tests (see Table $X$ ).

\section{B. Temperature Test History}

The objective of the temperature test was to simulate the conditions that the EBR-II bar samples experienced but without the influence of the neutron irradiation. The hottest in-reactor canister (i.e., lower canister No. 3) was chosen as the reference canister in an attempt to reproduce the severest thermal conditions that the EM bar samples had experienced. The temperature 
TABLE $X$. Temperature Test Sequence and Phases

\begin{tabular}{|c|c|c|c|c|c|c|c|c|c|c|c|c|c|c|}
\hline \multirow{2}{*}{$\begin{array}{c}\text { Test } \\
\text { Phase } \\
\end{array}$} & \multirow[b]{2}{*}{ Test Description } & \multicolumn{3}{|c|}{ Amber/SEC } & \multicolumn{3}{|c|}{ Toshiba/Si } & \multicolumn{3}{|c|}{$440 / B N$} & \multicolumn{2}{|c|}{ White/SEC } & \multicolumn{2}{|c|}{ Amber/BN } \\
\hline & & G17 & G18 & G19 & 9 & 10 & 11 & $\mathrm{~N} 20$ & $\mathrm{~N} 21$ & N22 & G37 & G38 & $3 \mathrm{~A}$ & $4 \mathrm{~A}$ \\
\hline 1 & Initial Examination & $\mathbf{x}$ & $\mathrm{X}$ & $\mathrm{x}$ & $\mathrm{x}$ & $\mathbf{x}$ & $\mathbf{x}$ & NT & NT & NT & $\mathbf{x}$ & $\mathbf{X}$ & NT & NT \\
\hline 2 & First Megger and Hipot & $\mathrm{x}$ & $\mathrm{X}$ & $\mathbf{x}$ & $\mathrm{x}$ & $\mathrm{X}$ & $\mathbf{x}$ & NT & NT & NT & $\mathbf{x}$ & $\mathbf{x}$ & NT & NT \\
\hline 3 & First Aging Oven Test & $\mathrm{X}$ & NA & NA & $\mathrm{x}$ & $\mathrm{X}$ & $\mathbf{x}$ & $\mathrm{X}$ & NA & NA & $\mathbf{x}$ & NA & $\mathrm{X}$ & NA \\
\hline 4 & Second Megger and Hipot & $\mathrm{X}$ & NA & NA & $\mathrm{X}$ & $\mathrm{X}$ & $\mathrm{X}$ & NT & NA & NA & $\mathrm{X}$ & NA & NT & NA \\
\hline 5 & Temperature Oven Test & $\mathrm{X}$ & $\mathrm{X}$ & $\mathrm{X}$ & $\mathrm{X}$ & $\mathrm{X}$ & $\mathbf{x}$ & $\mathrm{x}$ & $\mathrm{X}$ & $\mathbf{x}$ & $\mathrm{x}$ & $\mathbf{x}$ & $\mathbf{X}$ & $\mathbf{x}$ \\
\hline 6 & Third Megger and Hipot & $\mathrm{x}$ & $\mathrm{X}$ & $\mathrm{x}$ & $\mathrm{x}$ & $\mathrm{X}$ & $\mathbf{x}$ & $\mathrm{x}$ & $\mathrm{x}$ & $\mathbf{x}$ & $\mathbf{x}$ & $\mathbf{x}$ & $\mathbf{x}$ & $\mathrm{x}$ \\
\hline 7 & Second Aging Oven Test & $\mathbf{x}$ & NA & NA & $\mathrm{X}$ & $\mathbf{X}$ & $\mathbf{x}$ & $\mathrm{x}$ & NA & NA & $\mathrm{x}$ & NA & $\mathbf{X}$ & NA \\
\hline 8 & Fourth Megger and Hipot & $\mathbf{x}$ & NA & NA & $\mathbf{x}$ & $\mathbf{X}$ & $\mathbf{x}$ & $\mathrm{x}$ & NA & NA & $\mathbf{X}$ & NA & $\mathbf{X}$ & NA \\
\hline 9 & Final Examination & $\mathbf{x}$ & $\mathrm{x}$ & $\mathrm{x}$ & $\mathbf{x}$ & $\mathbf{x}$ & $\mathbf{x}$ & $\mathbf{x}$ & $\mathbf{x}$ & $\mathbf{x}$ & $\mathbf{X}$ & $\mathbf{x}$ & $\mathbf{x}$ & $\mathbf{X}$ \\
\hline
\end{tabular}

Key

$X=$ Performed the test or examination.

$N A=$ Not aged or tested as per "Test Plan" instructions.

NT $=$ Not tested or aged as received initially wet (uncured). 
of the canisters in the $J 2$ thimble of EBR-II were recorded with two thermocouples attached to the outside of each canister. In order to mimic the in-reactor temperature history, an attempt was made to simulate in a general way the temperature history experienced in-reactor. This required a time lag between the thermal conditions in-reactor and those in the No. 4 Oven containing the temperature test samples. The time delay in this temperature simulation was about 10 days.

The temperature history that the Canister No. 4 samples experienced during the temperature test (see Test Phase 5 of Table $X$ ) is presented in Fig. 18 . Evident in the temperature history of Fig. 18 is the attempt to simulate the shutdowns and startups associated with the actual EBR-II operating cycles. The reference ful1-power lower Canister No. 3 temperature was $616^{\circ} \mathrm{C}\left(1140^{\circ} \mathrm{F}\right)$. The total time at or slightly above this temperature was -83 days with the integrated time at this power (i.e., integral under Fig. 18 curve divided by $616^{\circ} \mathrm{C}$ ) being $\sim 103$ days. This temperature test temperature history is slightly different than but brackets the 92.5 full power days experienced by the samples in the irradiation program (see Sect. IV).

\section{Pretemperature Test Results}

The pretemperature test program which was conducted on the temperature test samples followed the procedures described previously in Sect. III. The pretemperature test program consisted of essentially three parts: (1) physical examinations, (2) electrical testing, and (3) accelerated aging. As identified in Table $X$, not all of the 13 temperature test bar samples were subjected to these pretemperature tests. The results and data obtained for those samples that were tested are presented in the next several subsections.

\section{Physical Examination}

The physical examination of the bar samples consisted of a visual inspection, a weighing, and dimensional measurements. Photographs of each bar sample were also taken both after the initial examination and after the first aging test. These photographs are presented in Appendix B. 


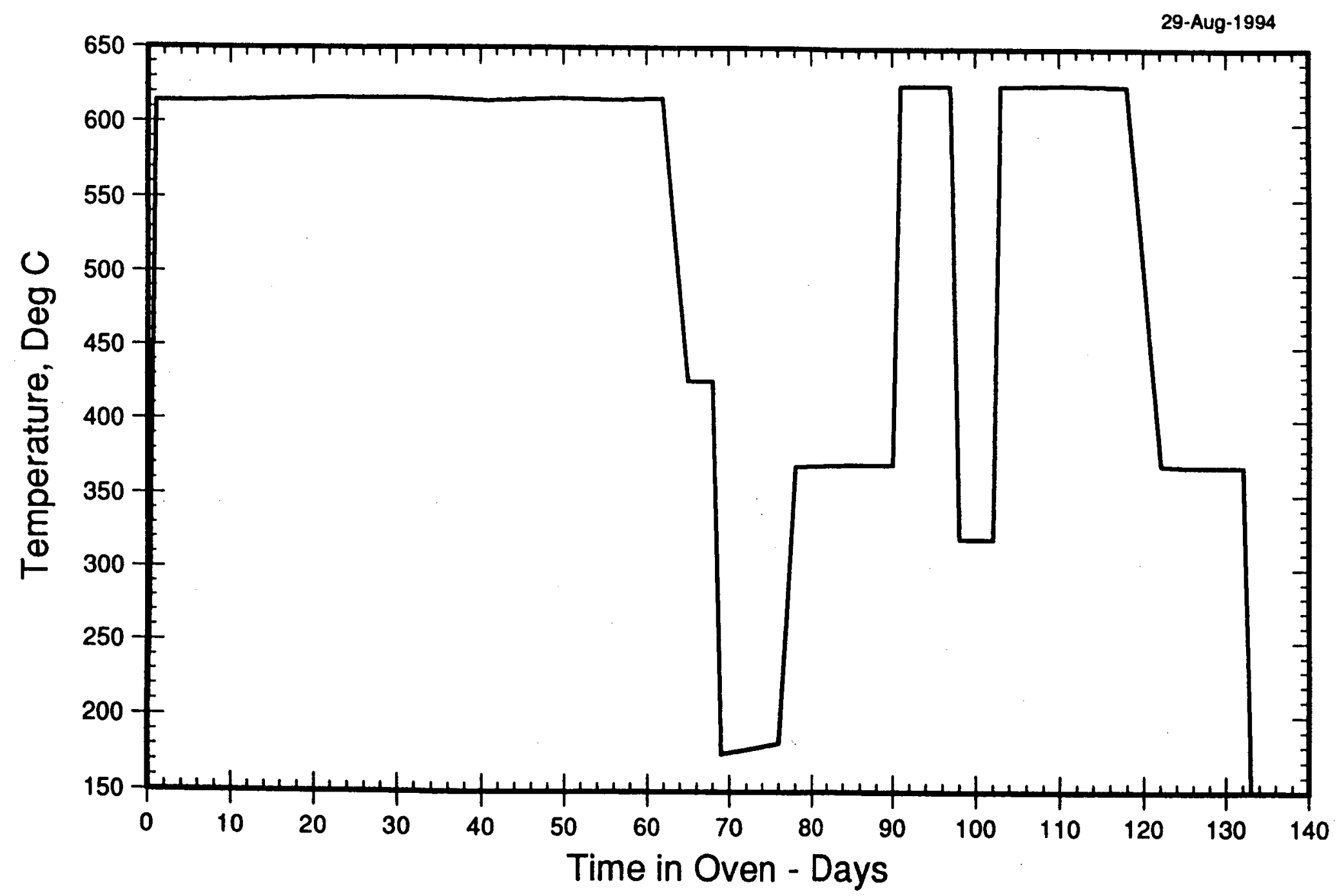

Fig. 18. Temperature Test Temperature History 
The results of the initial examination of the temperature test bar samples are shown in Table XI.

\section{Electrical Testing}

The electrical testing consisted of the standard electrical insulation Megger and Hipot measurements. The sample preparation and measurement procedures were described previously in Sect. III. These pretemperature electrical tests were performed both before and after the initial, or first, accelerated aging oven test.

In Table XII the results of the pretemperature electrical tests are presented.

\section{Accelerated Age Testing}

The initial, or first, pretemperature accelerated aging test on the 13 bar samples was conducted in the air ovens at ANL-East at temperature and voltage. A description of the methods and procedures is described in Sect. III. The temperature of the samples during the aging test was established at $-730^{\circ} \mathrm{C}$. The voltage impressed across the samples insulation was $600 \mathrm{~V}$ for the three Toshiba samples and $1500 \mathrm{~V}$ for the other remaining four samples that were age tested (see Table $X$ ). The aging time varied also with the three Toshiba samples experiencing $-500 \mathrm{~h}$, the three GE mica samples experiencing $-350 \mathrm{~h}$, and the single Nextel samples ran for only a short time $-46 \mathrm{~h}$.

The leakage current results for this first pretemperature aging test are presented in Tables XIII, XIV and XV for the Toshiba samples, the GE mica samples, and the GE Nextel samples, respectively.

\section{Posttemperature Test Results}

The posttemperature examinations and testing program essentially followed the requirements as specified in the program test plan of Ref. 2 . The posttemperature test sequence and phases are shown as items 6 through 9 in Table $X$. 
TABLE XI. Temperature Test Initial Examinations

\begin{tabular}{|c|c|c|c|c|}
\hline $\begin{array}{l}\text { Sample } \\
\text { Number }\end{array}$ & $\begin{array}{l}\text { Total Bar } \\
\text { Weight } \\
\text { (g) }\end{array}$ & $\begin{array}{l}\text { Insulation } \\
\text { Length } \\
\text { (in.) }\end{array}$ & $\begin{array}{l}\text { Insulation Areal Dimensions* } \\
\text { (in.) }\end{array}$ & Visual Observartions \\
\hline G17 & 88.6 & $\sim 10$ & $\begin{array}{l}0.570 / 0.369,0.549 / 0.377 \\
0.567 / 0.358,0.540 / 0.379 \\
0.533 / 0.308\end{array}$ & $\begin{array}{l}\text { Overlapped tape. Overall beige color } \\
\text { from Secon- } 5 \text {. Some flaking of Secon } \\
\text { especially near numbered end revealing } \\
\text { silvery under tape. }\end{array}$ \\
\hline G18 & 90.7 & $\sim 10$ & $\begin{array}{l}0.581 / 0.380,0.567 / 0.392 \\
0.557 / 0.377,0.549 / 0.414 \\
0.519 / 0.323\end{array}$ & $\begin{array}{l}\text { Overlapped tape. Overall beige color } \\
\text { from Secon-5 coating. Some minor } \\
\text { flaking of Secon along entire length of } \\
\text { sample revealing silvery tape beneath } \\
\text { Secon binder. }\end{array}$ \\
\hline G19 & 90.5 & $\sim 10$ & $\begin{array}{l}0.605 / 0.374,0.568 / 0.411 \\
0.553 / 0.395,0.537 / 0.389 \\
0.528 / 0.322\end{array}$ & $\begin{array}{l}\text { Overlapping tape. Overall beige color } \\
\text { appearance from Secon- } 5 \text { binder coating. } \\
\text { Very minor flaking of the Secon } \\
\text { revealing small areas of silvery tape } \\
\text { beneath Secon coating. }\end{array}$ \\
\hline 9 & 83.5 & $\sim 10$ & $\begin{array}{l}0.555 / 0.271,0.520 / 0.277 \\
0.506 / 0.265,0.493 / 0.259 \\
0.477 / 0.232\end{array}$ & $\begin{array}{l}\text { White woven mica insulation, potted } \sim 1 \\
\text { in. from either end. Insulation not } \\
\text { frayed. }\end{array}$ \\
\hline 10 & 83.3 & $\sim 10$ & $\begin{array}{l}0.509 / 0.274,0.508 / 0.289 \\
0.520 / 0.291,0.520 / 0.301 \\
0.444 / 0.222\end{array}$ & $\begin{array}{l}\text { Appearance the same as bar sample No. } \\
9 \text { except potting on the numbered end } \\
\text { extends part-way past } 1 \text { in. }\end{array}$ \\
\hline 11 & 83.4 & $\sim 10$ & $\begin{array}{l}0.571 / 0.256,0.506 / 0.261 \\
0.504 / 0.277,0.505 / 0.281 \\
0.462 / 0.218\end{array}$ & $\begin{array}{l}\text { White woven mica insulation, potted } \\
\sim 1-1 / 8 \text { in. from unnumbered end, } 1 \text { in. } \\
\text { from numbered end. Insulation not } \\
\text { frayed. }\end{array}$ \\
\hline $\mathrm{N} 20$ & Not Measured & Not Measured & Not Measured & Not Visually Inspected. \\
\hline $\mathrm{N} 21$ & Not Measured & Not Measured & Not Measured & Not Visually Inspected. \\
\hline
\end{tabular}


TABLE XI. (Contd.)

\begin{tabular}{|c|c|c|c|c|}
\hline $\begin{array}{l}\text { Sample } \\
\text { Number }\end{array}$ & $\begin{array}{l}\text { Total Bar } \\
\text { Weight } \\
\text { (g) }\end{array}$ & $\begin{array}{l}\text { Insulation } \\
\text { Length } \\
\text { (in.) }\end{array}$ & $\begin{array}{l}\text { Insulation Areal Dimensions* } \\
\text { (in.) }\end{array}$ & Visual Observations \\
\hline $\mathrm{N} 22$ & Not Measured & Not Measured & Not Measured & Not Visually Inspected. \\
\hline G37 & 83.1 & $\sim 10$ & $\begin{array}{l}0.555 / 0.310,0.545 / 0.361 \\
0.562 / 0.401,0.584 / 0.424 \\
0.549 / 0.320\end{array}$ & $\begin{array}{l}\text { Overlapped tape. Overall beige color } \\
\text { from Secon-5 binder coating. Very little } \\
\text { coating material flaked off. Two wraps } \\
\text { of ceramic insulating twine } \sim 1 / 4 \text { in. } \\
\text { from numbered end to tie down } \\
\text { insulation. }\end{array}$ \\
\hline G38 & 85.5 & $\sim 101 / 8$ & $\begin{array}{l}0.569 / 0.312,0.554 / 0.384 \\
0.560 / 0.413,0.619 / 0.434 \\
0.538 / 0.317\end{array}$ & $\begin{array}{l}\text { Overlapping tape. Overall beige color } \\
\text { from Secon- } 5 \text { coating. Very little coating } \\
\text { material flaked off. Two wraps of } \\
\text { ceramic insulating twice } \sim 1 / 8 \text { in. from } \\
\text { numbered end of sample to tie down } \\
\text { tape. Sample lumpy. }\end{array}$ \\
\hline $3 A-92$ & Not Measured & Not Measured & Not Measured & Not Visually Inspected. \\
\hline $4 A$ & Not Measured & Not Measured & Not Measured & Not Visually Inspected. \\
\hline
\end{tabular}

*Measured from numbered end at $\sim 0.25,2.5,5,7.5$, and -9.75 in. axial locations. 
TABLE XII. Temperature Test First and Second Electrical Measurement Results*

\begin{tabular}{|c|c|c|c|c|}
\hline \multirow[b]{2}{*}{$\begin{array}{l}\text { Sample } \\
\text { Number }\end{array}$} & \multicolumn{2}{|c|}{$\begin{array}{c}\text { Megger at } 1000 \mathrm{~V} \\
(\mathrm{G} \Omega)\end{array}$} & \multicolumn{2}{|c|}{$\begin{array}{c}\text { Hipot at } 3000 \vee \mathrm{AC} \\
(\mathrm{mA})\end{array}$} \\
\hline & $\begin{array}{c}\text { First Test } \\
\text { (Preaging) } \\
\end{array}$ & $\begin{array}{l}\text { Second Test } \\
\text { (Postaging) }\end{array}$ & $\begin{array}{l}\text { First Test } \\
\text { (Preaging) } \\
\end{array}$ & $\begin{array}{l}\text { Second Test } \\
\text { (Postaging) }\end{array}$ \\
\hline G17 & 6.8 & $>100$ & 0.237 & 0.187 \\
\hline G18 & 4.3 & N.A. & 0.230 & N.A. \\
\hline G19 & 4.2 & N.A. & 0.239 & N.A. \\
\hline 9 & 0.320 & $>100$ & 0.344 & 0.236 \\
\hline 10 & 0.180 & $>100$ & 0.365 & 0.231 \\
\hline 11 & 0.200 & $>100$ & 0.373 & 0.223 \\
\hline $\mathrm{N} 20$ & N.T. & N.T. & N.T. & N.T. \\
\hline N21 & N.T. & N.T. & N.T. & N.T. \\
\hline N22 & N.T. & N.T. & N.T. & N.T. \\
\hline G37 & 6.8 & 75 & 0.222 & 0.183 \\
\hline G38 & 5.8 & N.A. & 0.220 & N.A. \\
\hline $3 A-92$ & N.T. & N.T. & N.T. & N.T. \\
\hline $4 \mathrm{~A}$ & N.T. & N.T. & N.T. & N.T. \\
\hline
\end{tabular}

*0btained before (first electrical measurement) and after (second electrical measurement) the initial oven accelerated aging test.

$\underline{\text { Key }}$

N.A. = Not aged as per "Test Plan" instructions.

N.T. = Not tested as samples were received initially uncured. 
TABLE XIII. Temperature Test First Toshiba Aging Test Data

\begin{tabular}{|c|c|c|c|c|c|c|c|}
\hline \multirow[b]{2}{*}{ Date } & \multirow[b]{2}{*}{ Time } & \multirow[b]{2}{*}{$\begin{array}{c}\text { Elapsed } \\
\text { Time } \\
\text { (h) }\end{array}$} & \multirow[b]{2}{*}{$\begin{array}{c}\text { Appl ied } \\
\text { Voltage } \\
\text { (V) } \\
\end{array}$} & \multirow[b]{2}{*}{ Temp $\left({ }^{\circ} \mathrm{C}\right)$} & \multicolumn{3}{|c|}{ Leakage Current (mA) } \\
\hline & & & & & $\begin{array}{c}\text { Sample } \\
9 \\
\end{array}$ & $\begin{array}{c}\text { Sample } \\
10 \\
\end{array}$ & $\begin{array}{c}\text { Sample } \\
11 \\
\end{array}$ \\
\hline $5-03-93$ & 1545 & - & 110 & 730 & 0.39 & 0.31 & 0.45 \\
\hline $5-03-93$ & 1555 & - & 250 & 730 & 0.86 & 0.66 & 0.10 \\
\hline 5-03-93 & 1557 & - & 510 & 730 & 1.74 & 1.40 & 1.98 \\
\hline 5-03-93 & 1558 & 0.00 & 602 & 730 & 2.03 & 1.63 & 2.29 \\
\hline $5-03-93$ & 1630 & 0.25 & 700 & 730 & 1.81 & 1.50 & 2.00 \\
\hline $5-03-93$ & 1700 & 1.0 & 700 & 730 & 1.77 & 1.45 & 1.90 \\
\hline 5-04-93 & 0650 & 15.0 & 592 & 730 & 1.06 & 0.95 & 1.03 \\
\hline $5-04-93$ & 1100 & 19.0 & 596 & 730 & 1.01 & 0.90 & 0.96 \\
\hline 5-04-93 & 1615 & 24.0 & 608 & 730 & 0.95 & 0.85 & 0.90 \\
\hline 5-05-93 & 0640 & 38.5 & 593 & 730 & 0.82 & 0.75 & 0.79 \\
\hline 5-05-93 & 1459 & 44.6 & 591 & 730 & 0.79 & 0.71 & 0.75 \\
\hline $5-05-93$ & 1630 & 48.5 & 600 & 730 & 0.79 & 0.71 & 0.76 \\
\hline $5-06-93$ & 0645 & 62.7 & 601 & 730 & 0.72 & 0.66 & 0.70 \\
\hline $5-06-93$ & 1605 & 72.30 & 602 & 730 & 0.71 & 0.64 & 0.69 \\
\hline $5-07-93$ & 0700 & 87.3 & 597 & 730 & 0.67 & 0.60 & 0.65 \\
\hline $5-07-93$ & 1605 & 96.0 & 603 & 730 & 0.66 & 0.60 & 0.64 \\
\hline $5-10-93$ & 0645 & 156.5 & 599 & 730 & 0.62 & 0.56 & 0.61 \\
\hline $5-10-93$ & 1600 & 168.0 & 605 & 730 & 0.64 & 0.57 & 0.62 \\
\hline 5-11-93 & 0800 & 184.0 & 603 & 730 & 0.63 & 0.56 & 0.61 \\
\hline 5-11-93 & 1700 & 193.0 & 606 & 730 & 0.62 & 0.56 & 0.61 \\
\hline $5-12-93$ & 0800 & 208.0 & 605 & 730 & 0.62 & 0.55 & 0.61 \\
\hline $5-12-93$ & 1600 & 216.0 & 612 & 730 & 0.62 & 0.55 & 0.61 \\
\hline $5-13-93$ & 0800 & 231.0 & 612 & 730 & 0.62 & 0.55 & 0.61 \\
\hline 5-13-93 & 1600 & 239.0 & 626 & 730 & 0.63 & 0.56 & 0.62 \\
\hline $5-14-93$ & 0800 & 254.0 & 592 & 730 & 0.60 & 0.53 & 0.60 \\
\hline $5-14-93$ & 1600 & 262.0 & 603 & 730 & 0.62 & 0.55 & 0.61 \\
\hline $5-17-93$ & 0700 & 325.0 & 597 & 730 & 0.58 & 0.52 & 0.60 \\
\hline
\end{tabular}


TABLE XIII. (Contd.)

\begin{tabular}{|c|c|c|c|c|c|c|c|}
\hline & & & & & \multicolumn{3}{|c|}{ Leakage Current (mA) } \\
\cline { 6 - 9 } Date & Time & $\begin{array}{c}\text { Elapsed } \\
\text { Time } \\
(\mathrm{h})\end{array}$ & $\begin{array}{c}\text { Applied } \\
\text { Vol tage } \\
(\mathrm{V})\end{array}$ & Temp $\left({ }^{\circ} \mathrm{C}\right)$ & $\begin{array}{c}\text { Sample } \\
9\end{array}$ & $\begin{array}{c}\text { Sample } \\
10\end{array}$ & $\begin{array}{c}\text { Sample } \\
11\end{array}$ \\
\hline \hline $5-17-93$ & 1600 & 336.0 & 604 & 730 & 0.59 & 0.52 & 0.61 \\
\hline $5-18-93$ & 0700 & 351.0 & 598 & 730 & 0.57 & 0.51 & 0.59 \\
\hline $5-18-93$ & 1600 & 360.0 & 601 & 730 & 0.59 & 0.52 & 0.61 \\
\hline $5-19-93$ & 0700 & 375.0 & 605 & 730 & 0.59 & 0.52 & 0.63 \\
\hline $5-19-93$ & 1600 & 384.0 & 604 & 730 & 0.58 & 0.51 & 0.60 \\
\hline $5-20-93$ & 0700 & 399.0 & 605 & 730 & 0.55 & 0.51 & 0.60 \\
\hline $5-20-93$ & 1600 & 408.0 & 605 & 730 & 0.88 & 0.80 & 0.60 \\
\hline $5-21-93$ & 0700 & 423.0 & 599 & 730 & 0.57 & 0.50 & 0.60 \\
\hline $5-21-93$ & 1600 & 432.0 & 598 & 730 & 0.56 & 0.49 & 0.60 \\
\hline $5-24-93$ & 0700 & 495.0 & 598 & 730 & 0.57 & 0.51 & 0.60 \\
\hline $5-24-93$ & 1300 & 501.0 & 606 & 730 & 0.54 & 0.52 & 0.60 \\
\hline
\end{tabular}

\section{Physical Examination}

As part of the posttemperature physical examination phase, photographs were taken of each bar sample both just after the temperature test (i.e., Phase 5 in Table $X$ ) as well as after the second aging test (i.e., Phase 7 in Table $X)$. Representative photographs of samples after these two phases are presented in Appendix B. A complete physical examination, including a visual examination, sample weighing, and dimensional measurements was made as part of the final examination (i.e., Phase 9 of Table $X$ ).

The final examination results for the 13 temperature test bar samples are presented in Table XVI. 
TABLE XIV. Temperature Test First General Electric White Mica Aging Test Data

\begin{tabular}{|c|c|c|c|c|c|c|}
\hline \multirow[b]{2}{*}{ Date } & \multirow[b]{2}{*}{ Time } & \multirow[b]{2}{*}{$\begin{array}{c}\text { Elapsed } \\
\text { Time } \\
(\mathrm{h}) \\
\end{array}$} & \multirow[b]{2}{*}{$\begin{array}{c}\text { Appl ied } \\
\text { Voltage } \\
(V) \\
\end{array}$} & \multirow[b]{2}{*}{ Temp $\left({ }^{\circ} \mathrm{C}\right)$} & \multicolumn{2}{|c|}{$\begin{array}{c}\text { Leakage Current } \\
\text { (mA) }\end{array}$} \\
\hline & & & & & $\begin{array}{c}\text { Sample } \\
\text { G37 } \\
\end{array}$ & $\begin{array}{c}\text { Sample } \\
\text { G17 } \\
\end{array}$ \\
\hline $5-03-93$ & 1602 & - & 200 & 730 & 0.40 & 0.12 \\
\hline $5-03-93$ & 1605 & - & 500 & 730 & 1.01 & 0.29 \\
\hline $5-03-93$ & 1610 & - & 750 & 730 & 1.52 & 0.41 \\
\hline $5-03-93$ & 1612 & - & 1000 & 730 & 2.10 & 0.56 \\
\hline 5-03-94 & 1614 & - & 1250 & 730 & 2.74 & 0.70 \\
\hline 5-03-93 & 1617 & 0.0 & 1500 & 730 & 3.46 & 0.85 \\
\hline 5-03-93 & 1630 & 0.25 & 1500 & 730 & 3.77 & 0.82 \\
\hline $5-03-93$ & 1700 & 0.75 & 1500 & 730 & 4.04 & 0.76 \\
\hline 5-04-93 & 0645 & 14.5 & 1470 & 730 & 6.69 & 0.68 \\
\hline 5-04-93 & 1100 & 19.0 & 1470 & 730 & 4.04 & 0.69 \\
\hline $5-04-93$ & 1615 & 24.0 & 1476 & 730 & 7.48 & 0.72 \\
\hline $5-05-93$ & 0640 & 38.5 & 1463 & 730 & 7.93 & 0.73 \\
\hline $5-05-93$ & 1250 & 44.6 & 1459 & 730 & 8.09 & 0.74 \\
\hline $5-05-93$ & 1630 & 48.0 & 1509 & 730 & 8.52 & 0.80 \\
\hline $5-06-93$ & 0650 & 62.7 & 1505 & 730 & 8.78 & 0.82 \\
\hline $5-06-93$ & 1610 & 72.3 & 1502 & 730 & 8.92 & 0.85 \\
\hline 5-07-93 & 0700 & 87.3 & 1501 & 730 & 8.97 & $\ldots$ \\
\hline $5-07-93$ & 1610 & 96.0 & 1505 & 730 & 9.11 & $\ldots$ \\
\hline
\end{tabular}


TABLE XIV. (Contd.)

\begin{tabular}{|c|c|c|c|c|c|c|}
\hline & & & & & \multicolumn{2}{|c|}{$\begin{array}{c}\text { Leakage Current } \\
\text { (mA) }\end{array}$} \\
\cline { 6 - 8 } & & \multirow{2}{*}{$\begin{array}{c}\text { Elapsed } \\
\text { Time } \\
\text { Date }\end{array}$} & $\begin{array}{c}\text { Applied } \\
\text { Voltage } \\
(\mathrm{V})\end{array}$ & Temp $\left({ }^{\circ} \mathrm{C}\right)$ & $\begin{array}{c}\text { Sample } \\
\text { G37 }\end{array}$ & $\begin{array}{c}\text { Sample } \\
\text { G17 }\end{array}$ \\
\hline \hline $5-10-93$ & 0645 & 156.5 & 1502 & 730 & 9.39 & 0.86 \\
\hline $5-10-93$ & 1615 & 168.0 & 1505 & 730 & 9.42 & 0.87 \\
\hline $5-11-93$ & 0800 & 184.0 & 1505 & 730 & 9.47 & 0.89 \\
\hline $5-11-93$ & 1700 & 193.0 & 1503 & 730 & 9.60 & 0.88 \\
\hline $5-12-93$ & 0800 & 208.0 & 1506 & 730 & 9.54 & 0.91 \\
\hline $5-12-93$ & 1600 & 216.0 & 1534 & 730 & 9.49 & 0.91 \\
\hline $5-13-93$ & 0800 & 231.0 & $1498^{* \star}$ & 730 & 9.38 & 0.97 \\
\hline $5-13-93$ & 1600 & 239.0 & 1532 & 730 & 9.66 & 0.99 \\
\hline $5-14-93$ & 0800 & 254.0 & 1502 & 730 & 9.35 & 0.95 \\
\hline $5-14-93$ & 1600 & 262.0 & 1502 & 730 & 9.59 & 0.95 \\
\hline $5-17-93$ & 0700 & 325.0 & 1505 & 730 & 9.46 & 0.94 \\
\hline $5-17-93$ & 1605 & 336.0 & 1503 & 730 & 9.41 & 0.95 \\
\hline $5-18-93$ & 0700 & 351.0 & 1502 & 730 & 9.32 & 0.94 \\
\hline
\end{tabular}


TABLE XV. Temperature Test First General Electric Nextel Sample Aging Test Data

\begin{tabular}{|c|c|c|c|c|c|c|}
\hline \multirow[b]{2}{*}{ Date } & \multirow[b]{2}{*}{ Time } & \multirow[b]{2}{*}{$\begin{array}{c}\text { Elapsed } \\
\text { Time } \\
(\mathrm{h}) \\
\end{array}$} & \multirow[b]{2}{*}{$\begin{array}{c}\text { Appl ied } \\
\text { Voltage } \\
\text { (V) }\end{array}$} & \multirow[b]{2}{*}{ Temp $\left({ }^{\circ} \mathrm{C}\right)$} & \multicolumn{2}{|c|}{ Leakage Current $(\mathrm{mA})$} \\
\hline & & & & & $\begin{array}{c}\text { Sample } \\
3 A-92\end{array}$ & $\begin{array}{c}\text { Sample } \\
\text { N2O }\end{array}$ \\
\hline $8-28-93$ & 1030 & - & 250 & 730 & 0.03 & 0.05 \\
\hline $8-28-93$ & 1052 & - & 495 & 730 & 0.04 & 0.08 \\
\hline $8-28-93$ & 1055 & - & 790 & 730 & 0.06 & 0.08 \\
\hline $8-28-93$ & 1056 & - & 1000 & 730 & 0.07 & 0.15 \\
\hline $8-28-93$ & 1057 & - & 1278 & 730 & 0.09 & 0.20 \\
\hline $8-28-93$ & 1059 & 0.0 & 1500 & 730 & 0.11 & 0.23 \\
\hline $8-28-93$ & 1300 & 2.0 & 1500 & 730 & 0.11 & 0.20 \\
\hline $8-28-94$ & 1540 & 4.0 & 1525 & 730 & 0.11 & 0.18 \\
\hline $8-30-93$ & 0905 & 46.0 & 1490 & 730 & 0.12 & 0.13 \\
\hline
\end{tabular}


TABLE XVI. Temperature Test Final Examinations

\begin{tabular}{|c|c|c|c|c|}
\hline $\begin{array}{c}\text { Sample } \\
\text { Number }\end{array}$ & $\begin{array}{l}\text { Total Bar } \\
\text { Weight } \\
\text { (g) }\end{array}$ & $\begin{array}{l}\text { Insulation } \\
\text { Length } \\
\text { (in.) }\end{array}$ & $\begin{array}{l}\text { Insulation Areal Dimensions* } \\
\text { (in.) }\end{array}$ & Visual Observations \\
\hline G17 & 81.9 & $\sim 10-1 / 8$ & $\begin{array}{l}0.526 / 0.319,0.550 / 0.344 \\
0.567 / 0.358,0.580 / 0.366 \\
0.544 / 0.360\end{array}$ & $\begin{array}{l}\text { Outer wrap split in several places. Brownish to dark } \\
\text { brown color with silvery patches. Insulating twine } \\
\text { still on. }\end{array}$ \\
\hline G18 & 90.2 & $\sim 9-7 / 8$ & $\begin{array}{l}0.593 / 0.408,0.565 / 0.392 \\
0.547 / 0.387,0.556 / 0.397 \\
0.523 / 0.318\end{array}$ & $\begin{array}{l}\text { Overall appearance brown. Some darkening at } \\
\text { unnumbered end. }\end{array}$ \\
\hline G19 & 90.0 & $\sim 9-7 / 8$ & $\begin{array}{l}0.610 / 0.390,0.570 / 0.407 \\
0.552 / 0.405,0.538 / 0.388 \\
0.528 / 0.319\end{array}$ & $\begin{array}{l}\text { Overall appearance tan colored surface; some shiny } \\
\text { spots showing through. One edge appears to have a } \\
\text { black crystalline deposit especially at unnumbered } \\
\text { end. }\end{array}$ \\
\hline 9 & 81.9 & $\sim 10.0$ & $\begin{array}{l}0.553 / 0.291,0.547 / 0.250 \\
0.532 / 0.258,0.502 / 0.262 \\
0.471 / 0.242\end{array}$ & $\begin{array}{l}\text { Appearance seems little changed from original } \\
\text { except that there is some darkening at the } \\
\text { unnumbered end. Cu bar is also very badly oxidized } \\
\text { at that location. }\end{array}$ \\
\hline 10 & 81.6 & $\sim 10.0$ & $\begin{array}{l}0.507 / 0.295,0.518 / 0.271 \\
0.522 / 0.278,0.535 / 0.288 \\
0.461 / 0.288\end{array}$ & $\begin{array}{l}\text { Appearance little changed from original except for } \\
\text { the darkening at unnumbered end. Considerable } \\
\text { oxidation of } \mathrm{Cu} \text { at unnumbered end. }\end{array}$ \\
\hline 11 & 84.0 & $\sim 10-1 / 8$ & $\begin{array}{l}0.567 / 0.334,0.523 / 0.284 \\
0.528 / 0.283,0.502 / 0.267 \\
0.479 / 0.259\end{array}$ & $\begin{array}{l}\text { Weight includes broken screw. Appearance little } \\
\text { changed from original except for darkening at end } \\
\text { with broken screw. }\end{array}$ \\
\hline $\mathbf{N} 20$ & 82.2 & $\sim 10-1 / 8$ & $\begin{array}{l}0.443 / 0.208,0.486 / 0.281 \\
0.498 / 0.280,0.495 / 0.287 \\
0.483 / 0.253\end{array}$ & $\begin{array}{l}\text { White woven appearance with some discolorations } \\
\text { at numbered end. Color ranged from beige to } \\
\text { yellowish brown. }\end{array}$ \\
\hline N21 & 81.2 & $\sim 10.0$ & $\begin{array}{l}0.451 / 0.258,0.493 / 0.271 \\
0.484 / 0.274,0.490 / 0.278 \\
0.486 / 0.258\end{array}$ & Appearance the same as sample N20. \\
\hline
\end{tabular}


TABLE XVI. (Contd.)

\begin{tabular}{|c|c|c|l|l|}
\hline $\begin{array}{c}\text { Sample } \\
\text { Number }\end{array}$ & $\begin{array}{c}\text { Total Bar } \\
\text { Weight } \\
\text { (g) }\end{array}$ & $\begin{array}{c}\text { Insulation } \\
\text { Length } \\
\text { (in.) }\end{array}$ & $\begin{array}{c}\text { Insulation Areal Dimensions* } \\
\text { (in.) }\end{array}$ & \multicolumn{1}{|c|}{ Visual Observations } \\
\hline \hline N22 & 82.2 & $\sim 10.0$ & $\begin{array}{l}0.466 / 0.217,0.494 / 0.281, \\
0.489 / 0.280,0.481 / 0.279, \\
0.515 / 0.282\end{array}$ & Appearance the same as samples N20 and N21. \\
\hline G37 & 85.2 & $\sim 9-7 / 8$ & $\begin{array}{l}0.521 / 0.315,0.534 / 0.358, \\
0.550 / 0.368,0.549 / 0.366, \\
0.558 / 0.382\end{array}$ & $\begin{array}{l}\text { Very bright and shiny appearance. Most all of } \\
\text { original beige color gone. Exposed conductor bar } \\
\text { very thin and fragile. }\end{array}$ \\
\hline G38 & 84.2 & $\sim 10.0$ & $\begin{array}{l}0.595 / 0.313,0.556 / 0.388, \\
0.559 / 0.393,0.596 / 0.428, \\
0.543 / 0.326\end{array}$ & $\begin{array}{l}\text { Color appeared paler than original color. Little } \\
\text { change in overall appearance. Some darkening at } \\
\text { unnumbered end. }\end{array}$ \\
\hline 3A-92 & 80.6 & $\sim 9-7 / 8$ & $\begin{array}{l}0.452 / 0.195,0.482 / 0.293, \\
0.488 / 0.306,0.425 / 0.295, \\
0.452,0.186\end{array}$ & $\begin{array}{l}\text { Flaked white, very silvery appearance where white } \\
\text { has flaked off. Darkened at numbered end. }\end{array}$ \\
\hline 4A & 80.7 & $\sim 10.0$ & $\begin{array}{l}0.427 / 0.176,0.479 / 0.286, \\
0.482 / 0.297,0.482 / 0.293, \\
0.462 / 0.253\end{array}$ & $\begin{array}{l}\text { Appearance same as sample 3A except no } \\
\text { darkening at end. }\end{array}$ \\
\hline \hline
\end{tabular}

* Measured from numbered end at $\sim 0.25,2.5,5,7.5$, and $\sim 9.75$ in. axial locations. 


\section{Electrical Testing}

The posttemperature electrical testing was performed after the temperature test (i.e., Phase 6 in Table $X$ ) and after the second aging test (i.e., Phase 8 of Table $X$ ). The electrical testing again consisted of the standard electrical insulation Megger and Hipot tests. Sample preparation and measurement procedures were also identical to those described previously (see Sect. III).

The posttemperature test electrical measurement results are presented in Tables XVII and XVIII. Table XVII contains the electrical measurement results for the third electrical measurements performed on the temperature test samples (i.e., Phase 6 in Table 10). In Table XVIII, the fourth Megger and Hipot electrical measurement results are presented (i.e., Phase 8 in Table $x)$.

\section{Accelerated Age Testing}

The second aging test was conducted in this posttemperature test program phase. It was performed after the temperature test itself and was Phase 7 of the temperature test program (see Table $X$ ). Temperature and voltage conditions in the ovens that were impressed on the bar samples were the same as during the first temperature test oven aging test conducted during the pretemperature testing program.

The leakage current results obtained during the second accelerated aging test for the Toshiba samples are presented in Table XIX. As was the case for the previous Toshiba accelerated aging tests, the oven temperature was set at $-730^{\circ} \mathrm{C}$ with the voltage across the bars being $\sim 600 \mathrm{~V}$. The leakage current results for the GE insulation bar samples during the second accelerated aging test are tabulated in Table XX. Again, as was the case for the previous GE aging oven tests, a temperature of $-730^{\circ} \mathrm{C}$ was specified with the applied voltage being $\sim 1500 \mathrm{~V}$. 
TABLE XVII. Temperature Test Third Electrical Measurement Results*

\begin{tabular}{|c|c|c|}
\hline $\begin{array}{c}\text { Sample } \\
\text { Number }\end{array}$ & $\begin{array}{c}\text { Megger at } 1000 \mathrm{~V} \\
(\mathrm{GR})\end{array}$ & $\begin{array}{c}\text { Hipot at } 3000 \mathrm{~V} A C \\
(\mathrm{~mA})\end{array}$ \\
\hline \hline G17 & $>100$ & 0.195 \\
\hline G18 & $>100$ & 0.186 \\
\hline G19 & $>100$ & 0.181 \\
\hline 9 & $>100$ & 0.218 \\
\hline 10 & $>100$ & 0.228 \\
\hline 11 & $>100$ & 0.217 \\
\hline N20 & $>100$ & 0.190 \\
\hline N21 & $>100$ & 0.201 \\
\hline N22 & $>100$ & 0.202 \\
\hline G37 & $>100$ & 0.182 \\
\hline G38 & $>100$ & 0.183 \\
\hline $3 A-92$ & $>100$ & 0.192 \\
\hline $4 A$ & & 0.199 \\
\hline
\end{tabular}

*Obtained after the oven test in Canister 4 in a nitrogen gas atmosphere at EBR-II temperatures.

TABLE XVIII. Temperature Test Fourth Electrical Measurement Results*

\begin{tabular}{|c|c|c|}
\hline $\begin{array}{c}\text { Sample } \\
\text { Number }\end{array}$ & $\begin{array}{c}\text { Megger at } 1000 \mathrm{~V} \\
(\mathrm{G \Omega})\end{array}$ & $\begin{array}{c}\text { Hipot at } 3000 \mathrm{~V} \mathrm{AC} \\
(\mathrm{mA})\end{array}$ \\
\hline \hline $\mathrm{G} 17$ & $>100$ & 0.189 \\
\hline 9 & $>100$ & 0.229 \\
\hline 10 & $>100$ & 0.221 \\
\hline 11 & $>100$ & 0.208 \\
\hline $\mathrm{N} 20$ & $>100$ & 0.185 \\
\hline G37 & $>100$ & 0.184 \\
\hline $3 A-92$ & $>100$ & 0.189 \\
\hline
\end{tabular}

*Obtained after second accelerated aging oven test. 
TABLE XIX. Temperature Test Second Toshiba Aging Test Data

\begin{tabular}{|c|c|c|c|c|c|c|c|}
\hline \multirow[b]{2}{*}{ Date } & \multirow[b]{2}{*}{ Time } & \multirow[b]{2}{*}{$\begin{array}{c}\text { El apsed } \\
\text { Time } \\
(\mathrm{h}) \\
\end{array}$} & \multirow[b]{2}{*}{$\begin{array}{c}\text { Appl ied } \\
\text { Voltage } \\
\text { (V) }\end{array}$} & \multirow[b]{2}{*}{ Temp ${ }^{\circ} \mathrm{C}$} & \multicolumn{3}{|c|}{ Leakage Current (mA) } \\
\hline & & & & & $\begin{array}{c}\text { Sample } \\
9\end{array}$ & $\begin{array}{c}\text { Sample } \\
10 \\
\end{array}$ & $\begin{array}{c}\text { Sample } \\
11 \\
\end{array}$ \\
\hline $3-09-94$ & 0900 & $=$ & 191 & 729 & 0.04 & 0.03 & 0.04 \\
\hline $3-09-94$ & 0900 & - & 475 & 729 & 0.08 & 0.07 & 0.09 \\
\hline $3-09-94$ & 0900 & 0.0 & 595 & 729 & 0.10 & 0.08 & 0.11 \\
\hline $3-10-94$ & 0905 & 24.0 & 607 & 730 & 0.10 & 0.07 & 0.10 \\
\hline $3-11-94$ & 0900 & 48.0 & 607 & 729 & 0.10 & 0.07 & 0.10 \\
\hline $3-14-94$ & 0900 & 120.0 & 604 & 729 & 0.09 & 0.10 & 0.10 \\
\hline $3-16-94$ & 0900 & 168.0 & 603 & 731 & 0.10 & 0.07 & 0.11 \\
\hline $3-17-94$ & 0910 & 192.0 & 593 & 731 & 0.10 & 0.07 & 0.11 \\
\hline $3-18-94$ & 0900 & 216.0 & 588 & 729 & 0.12 & 0.09 & 0.13 \\
\hline $3-21-94$ & 0900 & 288.0 & 624 & 729 & 0.12 & 0.10 & 0.13 \\
\hline $3-22-94$ & 0900 & 312.0 & 585 & 729 & 0.12 & 0.09 & 0.13 \\
\hline $3-23-94$ & 0900 & 336.0 & 606 & 730 & 0.13 & 0.09 & 0.13 \\
\hline $3-24-94$ & 0900 & 360.0 & 583 & 730 & 0.11 & 0.09 & 0.12 \\
\hline $3-25-94$ & 0900 & 384.0 & 605 & 730 & 0.13 & 0.10 & 0.13 \\
\hline $3-28-94$ & 0900 & 456.0 & 581 & 731 & 0.12 & 0.09 & 0.13 \\
\hline 3-29-94 & 0900 & 480.0 & 593 & 731 & 0.13 & 0.10 & 0.14 \\
\hline $3-30-94$ & 0900 & 504.0 & 587 & 731 & 0.13 & 0.10 & 0.14 \\
\hline
\end{tabular}


TABLE XX. Temperature Test Second General Electric Aging Test Data

\begin{tabular}{|c|c|c|c|c|c|c|c|c|}
\hline & & & & \multicolumn{4}{|c|}{ Leakage Current (mA) } \\
\cline { 6 - 10 } Date & Time & $\begin{array}{c}\text { Elapsed } \\
\text { Time } \\
\text { (h) }\end{array}$ & $\begin{array}{c}\text { Applied } \\
\text { Voltage } \\
\text { (V) }\end{array}$ & Temp ${ }^{\circ} \mathrm{C}$ & $\begin{array}{c}\text { Sample } \\
\text { G37 }\end{array}$ & $\begin{array}{c}\text { Sample } \\
\text { G17 }\end{array}$ & $\begin{array}{c}\text { Sample } \\
\text { 3A-92 }\end{array}$ & $\begin{array}{c}\text { Sample } \\
\text { N20 }\end{array}$ \\
\hline \hline $1-24-94$ & 0900 & - & 237 & 733 & 0.02 & 0.13 & 0.01 & 0.04 \\
\hline $1-24-94$ & 0900 & - & 509 & 733 & 0.04 & 0.26 & 0.03 & 0.08 \\
\hline $1-24-94$ & 0900 & - & 756 & 733 & 0.06 & 0.38 & 0.04 & 0.12 \\
\hline $1-24-94$ & 0900 & - & 1004 & 733 & 0.07 & 0.46 & 0.04 & 0.16 \\
\hline $1-24-94$ & 0900 & - & 1324 & 733 & 0.10 & 0.70 & 0.70 & 0.22 \\
\hline $1-24-94$ & 0900 & 0.0 & 1497 & 733 & 0.10 & 0.75 & 0.07 & 0.25 \\
\hline $1-25-94$ & 1500 & 30.0 & 1524 & 736 & 0.07 & 0.81 & 0.08 & 0.22 \\
\hline $1-26-94$ & 0900 & 48.0 & 1504 & 734 & 0.07 & 0.78 & 0.08 & 0.20 \\
\hline $1-27-94$ & 0900 & 72.0 & 1506 & 735 & 0.07 & 0.76 & 0.09 & 0.21 \\
\hline $1-28-94$ & 0910 & 96.0 & 1489 & 735 & 0.06 & 0.73 & 0.09 & 0.19 \\
\hline $1-31-94$ & 0900 & 168.0 & 1425 & 735 & 0.07 & 0.73 & 0.10 & 0.19 \\
\hline $2-01-94$ & 0900 & 192.0 & 1470 & 735 & 0.06 & 0.72 & 0.10 & 0.18 \\
\hline $2-02-94$ & 0900 & 216.0 & 1508 & 735 & 0.06 & 0.73 & 0.10 & 0.19 \\
\hline $2-03-94$ & 0830 & 239.5 & 1508 & 735 & 0.06 & 0.75 & 0.10 & 0.19 \\
\hline $2-04-94$ & 0900 & 264.0 & 1497 & 735 & 0.05 & 0.75 & 0.10 & 0.20 \\
\hline $2-07-94$ & 0910 & 336.0 & 1492 & 734 & 0.06 & 0.75 & 0.11 & 0.20 \\
\hline $2-08-94$ & 0900 & 360.0 & 1486 & 734 & 0.05 & 0.75 & 0.11 & 0.21 \\
\hline $2-13-94$ & 1900 & 490.0 & 1504 & 733 & 0.05 & 0.80 & 0.12 & 0.21 \\
\hline $2-14-94$ & 0930 & 504.0 & 1485 & 734 & 0.05 & 0.79 & 0.12 & 0.22 \\
\hline
\end{tabular}




\section{SUMMARY OF POSTIRRADIATION TESTS}

The irradiation test phase and postirradiation examination and test phase of the EM pump insulation irradiation test program is described in this report. These tests constitute the second and third parts of a three phase program which includes the irradiation of 39 insulation bar samples in the $J 2$ thimble of EBR-II. The first part of this comprehensive evaluation program consisted of the preirradiation examinations and tests which essentially duplicated the postirradiation tests on selected samples, as described previously in Ref. 1. A comparison of the preirradiation results with the postirradiation results will help establish the suitability of the selected EM pump insulation material for application in the ALMR.

The centerpiece of this pump insulation performance test and evaluation program was the irradiation of 39 selected insulation bar samples in the $\mathrm{J} 2$ thimble of EBR-II. These samples representing a cross section of insulation materials and binders were irradiated in three nitrogen gas-filled canisters. The EBR-II irradiation which began in Run No. 165A reached the temperature stabilized sample condition on August 1, 1993. The test was conducted in the $\mathrm{J} 2$ thimble of the Nuclear Instrument Test Facility (NITF) which is located outside the core in the radial shield region. The irradiation test was designated the NI-10 test; the samples experienced a -92.5 day irradiation cycle. The temperatures that the samples were subjected to were measured with two thermocouples located on the outer surface of each canister.

Measured temperatures were $\sim 830^{\circ} \mathrm{F}\left(444^{\circ} \mathrm{C}\right)$ on the upper canister, $\sim 1000^{\circ} \mathrm{F}$ $\left(538^{\circ} \mathrm{C}\right)$ on the middle canister, and $\sim 1140^{\circ} \mathrm{F}\left(616^{\circ} \mathrm{C}\right)$ on the lower canister, which was located closest to the core. The calculated neutron fluences that the insulation samples experienced were within the range that was desired.

A fourth NI-10 test canister, containing EM insulation bar samples similar to those under irradiation was filled with nitrogen, sealed, and placed in an aging oven at ANL-East. This "temperature test" subjected the samples to the temperature history experienced by the hottest canister undergoing irradiation (lower canister). The oven was therefore set to $\sim 1140^{\circ} \mathrm{F}\left(616^{\circ} \mathrm{C}\right)$ with its temperature history mimicking the $\sim 92.5$ day irradiation cycle. 
In the initial preirradiation and final postirradiation examinations and tests the focus was on evaluating the physical and electrical insulation characteristics of three types of insulation bar samples. Two of these insulation types, white mica and amber mica, were fabricated by the General Electric Co. using Secon-5 potting compound as a binder. The third insulation material evaluated in this study was splitting mica with silicon binder which was fabricated by the Toshiba Corp. All of the approximately 60 insulation bar samples tested in this program consisted of a small copper bar $(-10$ in. long by $\sim 0.5$ in. $x \sim 0.25$ in. cross section) and were wrapped with various combinations of insulation tape and binder. The weight of these samples was approximately $85 \mathrm{~g}$. The physical examinations that were performed on these samples included a visual inspection, a weighing, dimensional checks, and photographs of each sample. The electrical tests consisted of a direct current insulation resistance test (i.e., Megger test) and an alternating current leakage test (i.e., Hipot test). These electrical tests were performed on the samples both before and after an accelerated aging test.

The accelerated aging tests were conducted in the ovens at ANL-East with the radioactive samples aged in an oven shipped from ANL-East to ANL-West. The sample temperature was $\sim 1350^{\circ} \mathrm{F}$ with the applied voltage being either $600 \mathrm{~V}$ AC (splitting mica samples) or $1500 \mathrm{VAC}$ (white and amber mica samples). These aging tests were scheduled for $\sim 3$ weeks duration. However, the poor electrical performance observed for the white mica samples, as measured by the leakage current, dictated that the aging test for the white and amber samples be terminated after $\sim 2$ weeks duration. Typical leakage currents for the white mica insulation bars during the aging test were approximately an order of magnitude higher $(\sim 10 \mathrm{~mA})$ than the amber and splitting mica $(\sim 1$ $\mathrm{mA})$.

Based on the relatively poor electrical performance of the white mica as determined in the initial age test, a development program was initiated at GE to find a substitute material. Accelerated age tests were performed at ANLEast on replacement insulation wrapping material which included ceramic tape (i.e., Nextel tape), combinations of amber and ceramic tape, and other binder materials (i.e., boron nitride). After several failures, a ceramic tape/boron nitride insulation system performed satisfactorily in a $\sim 2$ week age test. 


\section{ACKNOWLEDGMENTS}

This experimental study is the result of the cooperation and contributions of several people. Much thanks are owed. to E. W. O'Hare and R. A. Jaross at ANL-East for their assistance in the experimental setup and operations. The direction and program planning provided by W. Kwant, J. Shukal, and J. M. Collett of General Electric is also gratefully acknowledged. T. J. Lucitt at ANL-East prepared the figures for this report for which we are grateful. Also the following technical support personnel at ANL-West contributed their talents to the success of this program: D. C. Hendrix, E. A. Reseigh, G. M. Schwartzenburger, and R. M. Tessner. In addition, we would like to thank, at ANL-West, K. J. Christiansen who provided health and safety support and E. K. Hahn, who was the photographer who provided the ANL-West pictures.

\section{REFERENCES}

1. W. A. Bezella et al., "Electromagnetic Pump Insulation Preirradiation Test Report," Argonne National Laboratory Report, ANL-IFR-229 (May 1994).

2. J. M. Collett, "Insulation Irradiation Testing Requirements, " General Electric Report, 23A3915, Revision C (March 1993).

3. J. M. Collett, "NI-10, EM Pump Insulation Materials Irradiation Data Package-Part 1: "Experiment Description," General Electric Report, A1-10993094, Revision C (June 28, 1993). 


\section{APPENDIX A}

\section{NEUTRON FLUX AND ACTIVITY ESTIMATES}

\section{A. Neutron Flux Estimate at Bar Samples}

The neutron flux at the center of the bar sample locations in the $\mathrm{J} 2$ thimble of the EBR-II Reactor is predicted using the TWODANT transport theory code. The $S^{8}$ discrete ordinates approximation and 30-group cross-section set were used. The group structure is fine enough to track the epithermal flux we11. There is one thermal group, whose cross sections were obtained from the THERMOS code. Cross sections for the core and blanket are based on ENDF/B Version 5.2 data, but cross sections for regions beyond there are based on Version 1 data.

The reactor was modeled with $R Z$ geometry. This precluded modeling azimuthal asymmetries, including explicit representation of the $\mathrm{J} 2$ thimble. It should be adequate to use the flux in the outer blanket region at the $\mathrm{J} 2$ thimble location. Materials present in the aximuthal sector encompassing the J2 thimble, rather than radially averaged compositions, were used. This approximation should give a reasonable representation of the flux at the $\mathrm{J} 2$ thimble.

There are three sample canisters stacked one above the other in the J2 thimble. Each sample is a rod about 11 in. long and each canister contains 13 samples arranged in -3 in. diameter circular pattern. The axial center of the bottom canister is at the core axial midplane. The canister center is 26 in. apart along the axis of the $\mathrm{J} 2$ thimble. Note, however, that the $\mathrm{J} 2$ thimble axis is tilted $10.863^{\circ}$ away from vertical, with the top being radially further out than the bottom. This implies that the samples get further from the core (deeper into the outer shield), the further up the thimble they are.

The neutron flux has been edited at three locations, the centers of the bottom, middle, and top canisters. These three spectra are listed in Table Al. At the bottom of the table are shown the fast flux (groups 1 through 9 , 
TABLE Al. Neutron Spectrum at Center of Each Canister

\begin{tabular}{|c|c|c|c|c|}
\hline Group & $\mathrm{E}_{\max }(\mathrm{eV})$ & Bottom & Middle & Top \\
\hline 1 & $1.00 \mathrm{E}+07$ & $4.40 \mathrm{E}+07$ & $5.92 \mathrm{E}+06$ & $4.62 \mathrm{E}+05$ \\
\hline 2 & $6.06 \mathrm{E}+06$ & $1.78 \mathrm{E}+08$ & $2.11 \mathrm{E}+07$ & $1.68 E+06$ \\
\hline 3 & $3.68 E+06$ & $5.21 \mathrm{E}+08$ & $5.35 E+07$ & $4.60 \mathrm{E}+06$ \\
\hline 4 & $2.23 E+06$ & $1.61 \mathrm{E}+\infty 9$ & $1.74 \mathrm{E}+08$ & $1.58 \mathrm{E}+07$ \\
\hline 5 & $1.35 \mathrm{E}+06$ & $3.10 \mathrm{E}+09$ & $2.95 \mathrm{E}+08$ & $2.58 \mathrm{E}+07$ \\
\hline 6 & $8.21 \mathrm{E}+05$ & $4.57 \mathrm{E}+09$ & $3.84 \mathrm{E}+08$ & $3.14 \mathrm{E}+07$ \\
\hline 7 & $4.98 \mathrm{E}+05$ & $6.55 \mathrm{E}+09$ & $4.68 \mathrm{E}+08$ & $3.78 \mathrm{E}+07$ \\
\hline 8 & $3.02 \mathrm{E}+05$ & $9.34 \mathrm{E}+09$ & $5.63 E+08$ & $4.57 \mathrm{E}+07$ \\
\hline 9 & $1.83 E+05$ & $1.21 \mathrm{E}+10$ & $6.79 E+08$ & $5.49 \mathrm{E}+07$ \\
\hline 10 & $1.11 \mathrm{E}+05$ & $1.59 \mathrm{E}+10$ & $7.78 \mathrm{E}+08$ & $6.62 E+07$ \\
\hline 11 & $6.74 E+04$ & $1.99 \mathrm{E}+10$ & $9.33 \mathrm{E}+08$ & $7.92 \mathrm{E}+07$ \\
\hline 12 & $4.09 \mathrm{E}+04$ & $2.46 \mathrm{E}+10$ & $1.13 E+09$ & $9.42 \mathrm{E}+07$ \\
\hline 13 & $2.48 \mathrm{E}+04$ & $3.31 \mathrm{E}+10$ & $1.33 \mathrm{E}+09$ & $1.12 \mathrm{E}+08$ \\
\hline 14 & $1.50 \mathrm{E}+04$ & $3.78 \mathrm{E}+10$ & $1.70 \mathrm{E}+09$ & $1.40 \mathrm{E}+08$ \\
\hline 15 & $9.12 \mathrm{E}+03$ & $4.32 \mathrm{E}+10$ & $1.88 \mathrm{E}+09$ & $1.57 \mathrm{E}+08$ \\
\hline 16 & $5.53 E+03$ & $5.02 \mathrm{E}+10$ & $1.92 \mathrm{E}+09$ & $1.66 \mathrm{E}+08$ \\
\hline 17 & $3.36 \mathrm{E}+03$ & $4.40 \mathrm{E}+10$ & $1.85 \mathrm{E}+09$ & $1.58 \mathrm{E}+08$ \\
\hline 18 & $2.04 E+03$ & $6.87 \mathrm{E}+10$ & $2.66 \mathrm{E}+09$ & $2.28 E+08$ \\
\hline 19 & $1.23 \mathrm{E}+03$ & $7.11 \mathrm{E}+10$ & $3.26 \mathrm{E}+09$ & $2.70 \mathrm{E}+08$ \\
\hline 20 & $7.48 \mathrm{E}+02$ & $7.44 \mathrm{E}+10$ & $3.81 \mathrm{E}+09$ & $3.18 \mathrm{E}+08$ \\
\hline 21 & $4.54 \mathrm{E}+02$ & $7.79 \mathrm{E}+10$ & $4.45 \mathrm{E}+09$ & $3.75 \mathrm{E}+08$ \\
\hline 22 & $2.75 \mathrm{E}+02$ & $8.19 \mathrm{E}+10$ & $5.17 \mathrm{E}+09$ & $4.33 E+08$ \\
\hline 23 & $1.67 \mathrm{E}+02$ & $8.58 \mathrm{E}+10$ & $5.91 \mathrm{E}+09$ & $4.96 \mathrm{E}+08$ \\
\hline 24 & $1.01 \mathrm{E}+02$ & $8.95 E+10$ & $6.62 \mathrm{E}+09$ & $5.72 \mathrm{E}+08$ \\
\hline 25 & $6.14 E+01$ & $9.27 \mathrm{E}+10$ & $7.36 \mathrm{E}+09$ & $6.54 \mathrm{E}+08$ \\
\hline 26 & $3.73 E+01$ & $1.95 \mathrm{E}+11$ & $1.78 E+10$ & $1.71 E+09$ \\
\hline 27 & $2.26 \mathrm{E}+01$ & $1.98 \mathrm{E}+11$ & $2.09 \mathrm{E}+10$ & $2.13 \mathrm{E}+09$ \\
\hline 28 & $1.37 \mathrm{E}+01$ & $1.94 \mathrm{E}+11$ & $2.36 \mathrm{E}+10$ & $2.52 \mathrm{E}+09$ \\
\hline 29 & $5.04 \mathrm{E}+00$ & $1.83 E+11$ & $2.55 \mathrm{E}+10$ & $2.92 \mathrm{E}+09$ \\
\hline 30 & 4.14E-01 & $6.60 \mathrm{E}+11$ & $1.48 \mathrm{E}+11$ & $2.38 E+10$ \\
\hline Fast & & $3.80 \mathrm{E}+10$ & $2.64 \mathrm{E}+09$ & $2.18 E+08$ \\
\hline Total & & $2.38 \mathrm{E}+12$ & $2.89 \mathrm{E}+11$ & $3.76 E+10$ \\
\hline
\end{tabular}

The flux is normalized to full reactor power, $62.5 \mathrm{MWt}$. 
i.e., above $0.1 \mathrm{MeV}$ ) and the total flux. In all cases, the flux is normalized to yield a total reactor power of $62.5 \mathrm{MWt}$, i.e., full power. The predicted total flux is $2.38 \times 10^{12}$ in the bottom canister, $2.89 \times 10^{11}$ in the middle canister, and $3.7610^{10}$ in the top canister.

\section{B. Activity of General Electric Bar Samples}

Measurements were made to determine the radioactivity level of the GE irradiated bar samples just prior to subjecting them to their postirradiation tests and examinations. These health physics measurements were required to aid in minimizing the doses received by the technicians conducting the posttest examinations.

Tables A2, A3, and A4 beta and gamma activation levels, taken at the bar surface, are reported for Canisters 1, 2, and 3, respectively. As Table A2 indicates, no activity was measured for the Canister 1 samples located in the J2 assembly carrier farthest from the reactor core. The high activation levels of the bar samples in Canister 3 closest to the reactor core, are evident in Table A4.

Also provided in Tables $A 2$ and $A 3$ are the type of wrapping provided for the posttest examinations. The age testing disposition (yes or no) for each sample is also indicated in these tables.

Surface contaminations measurements were also made for two of the bar samples in Canister 2. These two high-activity-level bar samples were Samples G7 and G8. For Sample G7 a surface smear of 8,000 dpm was recorded with Sample G8 indicating a surface smear count of $30,000 \mathrm{dpm}$. 
TABLE A2. Activity of General Electric Samples in Canister 1

\begin{tabular}{|c|c|c|c|c|c|}
\hline $\begin{array}{c}\text { Storage } \\
\text { Tube }\end{array}$ & $\begin{array}{c}\text { Sample } \\
\text { ID No. }\end{array}$ & $\begin{array}{c}\text { Activation } \\
\text { Beta-Gamma }\end{array}$ & $\begin{array}{c}\text { Activation } \\
\text { Gamma }\end{array}$ & $\begin{array}{c}\text { Type of } \\
\text { Wrap }\end{array}$ & $\begin{array}{c}\text { Age } \\
\text { Test }\end{array}$ \\
\hline 1 & G1 & - & - & Al-SS-A1 & Yes \\
\hline 2 & N10 & - & - & Al-SS-A1 & Yes \\
\hline 3 & G22 & - & - & Al-SS-Al & Yes \\
\hline 5 & G2 & - & - & Al-SS-Al & Yes \\
\hline 7 & G3 & - & - & Al-SS-Al & Yes \\
\hline 8 & N11 & - & - & Al-SS-Al & Yes \\
\hline 9 & G21 & - & - & Al-SS-Al & Yes \\
\hline 10 & G4 & - & - & Al only & No \\
\hline 11 & G5 & - & - & Al only & No \\
\hline 13 & N12 & - & - & Al only & No \\
\hline
\end{tabular}

TABLE A3. Activity of General Electric Samples in Canister 2

\begin{tabular}{|c|c|l|c|c|c|}
\hline $\begin{array}{c}\text { Storage } \\
\text { Tube }\end{array}$ & $\begin{array}{c}\text { Sample } \\
\text { ID No. }\end{array}$ & $\begin{array}{c}\text { Activation } \\
\text { Beta-Gamma }\end{array}$ & $\begin{array}{c}\text { Activation } \\
\text { Gamma }\end{array}$ & $\begin{array}{c}\text { Type of } \\
\text { Wrap }\end{array}$ & $\begin{array}{c}\text { Age } \\
\text { Test }\end{array}$ \\
\hline 1 & G6 & $200 \mathrm{mR} / \mathrm{h}$ & $100 \mathrm{mR} / \mathrm{h}$ & SS only & Yes \\
\hline 2 & N13 & 80 & 60 & SS only & Yes \\
\hline 3 & N14 & Background $\star$ & - & SS only & Yes \\
\hline 4 & $3 A$ & 400 & 200 & Al only & No \\
\hline 5 & G7 & 450 & 220 & SS only & Yes \\
\hline 6 & G26 & 100 & 60 & SS only & Yes \\
\hline 7 & G8 & 500 & 250 & SS only & Yes \\
\hline 8 & N15 & Background $*$ & - & SS only & Yes \\
\hline 9 & N16 & Background $*$ & - & Al only & No \\
\hline 10 & G9 & 380 & 200 & Al only & No \\
\hline 11 & G10 & 400 & 200 & Al only & No \\
\hline 12 & G11 & 400 & 200 & Al only & No \\
\hline 13 & $2 A$ & 400 & 200 & SS only & Yes \\
\hline
\end{tabular}

*Background is 60 . 
TABLE A4. Activity of General Electric Samples in Canister 3

\begin{tabular}{|c|c|c|l|l|c|}
\hline $\begin{array}{c}\text { Storage } \\
\text { Tube }\end{array}$ & $\begin{array}{c}\text { Sample } \\
\text { ID No. }\end{array}$ & $\begin{array}{c}\text { Activation } \\
\text { Beta-Gamma }\end{array}$ & $\begin{array}{c}\text { Activation } \\
\text { Gamma }\end{array}$ & $\begin{array}{c}\text { Type of } \\
\text { Wrap }\end{array}$ & $\begin{array}{c}\text { Age } \\
\text { Test }\end{array}$ \\
\hline 1 & G12 & $1.4 \mathrm{R} / \mathrm{h}$ & $600 \mathrm{mR} / \mathrm{h}$ & Al only & No \\
\hline 2 & $\mathrm{~N} 17$ & 600 & 600 & SS only & Yes \\
\hline 3 & $\mathrm{G} 33$ & 600 & 500 & SS only & Yes \\
\hline 5 & $\mathrm{G} 13$ & $1.6 \mathrm{R} / \mathrm{h}$ & $1 \mathrm{R} / \mathrm{h}$ & $\mathrm{Al}$ only & No \\
\hline 7 & $\mathrm{G} 14$ & $1.5 \mathrm{R} / \mathrm{h}$ & $1 \mathrm{R} / \mathrm{h}$ & SS only & Yes \\
\hline 8 & $\mathrm{~N} 18$ & 500 & 500 & Al only & No \\
\hline 9 & $\mathrm{G} 32$ & 600 & 500 & Al only & No \\
\hline 10 & $G 15$ & $1.2 \mathrm{R} / \mathrm{h}$ & 700 & Al only & No \\
\hline 11 & $G 16$ & $1.2 \mathrm{R} / \mathrm{h}$ & 700 & Al only & No \\
\hline 13 & $\mathrm{~N} 19$ & 500 & 500 & Al only & No \\
\hline
\end{tabular}


$-76-$

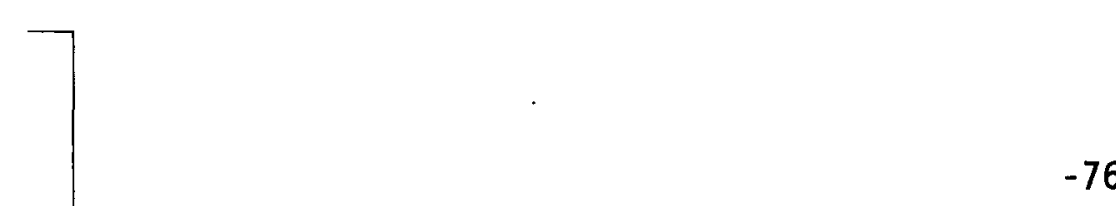


$-77-$

APPENDIX B

REPRESENTATIVE PHOTOGRAPHS 
TABLE B1. General Electric and Toshiba Bar Sample Conditions After Irradiation

\begin{tabular}{|c|c|c|l|}
\hline Sample & Good & Poor & \multicolumn{1}{|c|}{ Comments } \\
\hline \hline \multicolumn{3}{|c|}{} & \multicolumn{3}{|l|}{ General Electric Samples } \\
\hline N10 & $X$ & & Brown - Insulation looks good. \\
\hline N11 & $X$ & & Brown - Insulation looks good, flaked a little. \\
\hline N12 & $X$ & & Brown - Insulation looks good, flaked a little. \\
\hline N13 & $X$ & & $\begin{array}{l}\text { White - Unraveled on hole end, slightly } \\
\text { discolored. }\end{array}$ \\
\hline N14 & & $X$ & White - Unraveled on ID end, slightly discolored. \\
\hline N15 & & $X$ & $\begin{array}{l}\text { White - Unraveled on both ends, slightly } \\
\text { discolored. }\end{array}$ \\
\hline N16 & & $X$ & $\begin{array}{l}\text { White - Unraveled on both ends, slightly } \\
\text { discolored. }\end{array}$ \\
\hline N17 & & $X$ & $\begin{array}{l}\text { White - Unraveled on ID end, otherwise, looks } \\
\text { good. }\end{array}$ \\
\hline N18 & & $X$ & White - Unraveled on both ends, otherwise, good. \\
\hline N19 & & $X$ & White - Unraveled on both ends, green on one edge. \\
\hline 2A & $X$ & & White - Insulation good, discolored a little. \\
\hline 3A & & $X$ & White - Insulation unwrapped on ID end. (one turn) \\
\hline G1 & & $X$ & White - Slightly unraveled and discolored on ends. \\
\hline G2 & $X$ & & Brown - unraveled on ID end. \\
\hline G3 & $X$ & & White - Slightly unraveled on hole end. \\
\hline G4 & $X$ & & Brown - Insulation looks good, flaked a little. \\
\hline G5 & $X$ & & White - Slightly unraveled and discolored on ends. \\
\hline G6 & $X$ & & Brown - Insulation good, discolored a little. \\
\hline G7 & $X$ & & Brown - Insulation good, discolored a little. \\
\hline G8 & $X$ & & Brown - Insulation good, discolored a little. \\
\hline G9 & $X$ & & Brown - Insulation good, discolored a little. \\
\hline G10 & $X$ & & Brown - Insulation good, discolored a little. \\
\hline G11 & $X$ & & Brown - Insulation good, discolored a little. \\
\hline G12 & $X$ & & Brown - Insulation good, discolored a little. \\
\hline
\end{tabular}


TABLE B1. (Contd.)

\begin{tabular}{|c|c|c|c|}
\hline Sample & Good & Poor & Comments \\
\hline \multicolumn{4}{|r|}{ General Electric Samples } \\
\hline G13 & 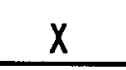 & & Brown - Insulation good, green color on one edge. \\
\hline G14 & $\underline{x}$ & & Brown - Insulation good, discolored a little. \\
\hline G15 & $x$ & & $\begin{array}{l}\text { Brown - Insulation good, green and black color on } \\
\text { one edge. }\end{array}$ \\
\hline G16 & $\mathbf{x}$ & & Brown - Insulation very good condition \\
\hline G21 & $\underline{x}$ & & Brown - Insulation looks good, flaked a little. \\
\hline G22 & $x$ & & Brown - Insulation looks good. \\
\hline G26 & $x$ & & Brown - Unraveled on ID end, slightly discolored. \\
\hline G32 & $x$ & & Brown - Insulation looks good discolored. \\
\hline G33 & $x$ & & Brown - Insulation looks good. \\
\hline \multicolumn{4}{|r|}{ Toshiba Samples } \\
\hline 1 & $x$ & & Appears normal \\
\hline 2 & $x$ & & Appears normal \\
\hline 3 & $\mathrm{x}$ & & Appears normal \\
\hline 4 & $x$ & & $\begin{array}{l}\text { Cu appears oxidized. More green color on } \\
\text { insulation. }\end{array}$ \\
\hline 5 & $x$ & & $\begin{array}{l}\text { Cu appears oxidized. More green color on } \\
\text { insulation. }\end{array}$ \\
\hline 6 & $\mathrm{x}$ & & Cu appears oxidized on one end. Some green color. \\
\hline
\end{tabular}




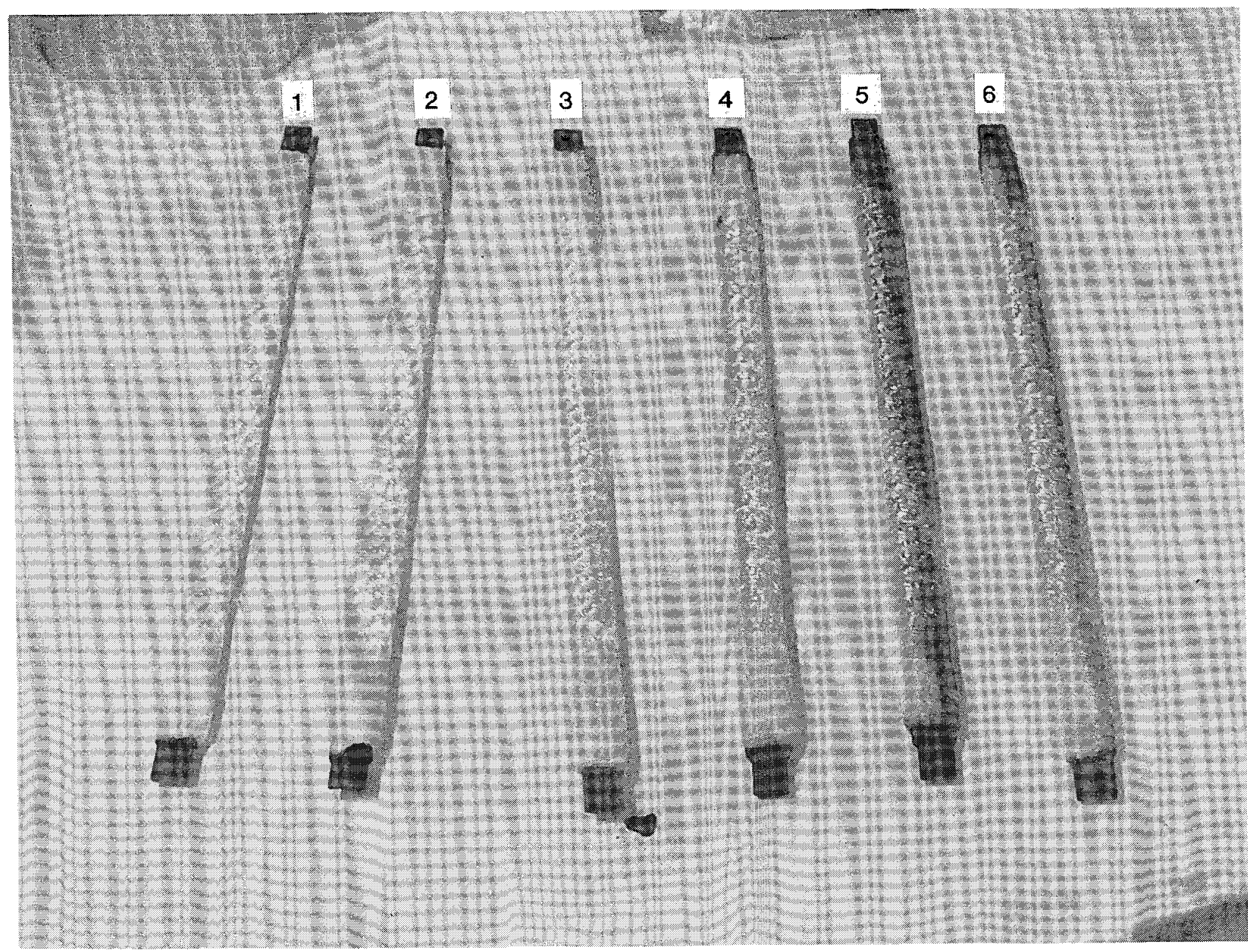

Fig. B1. Toshiba Bar Samples After Irradiation 


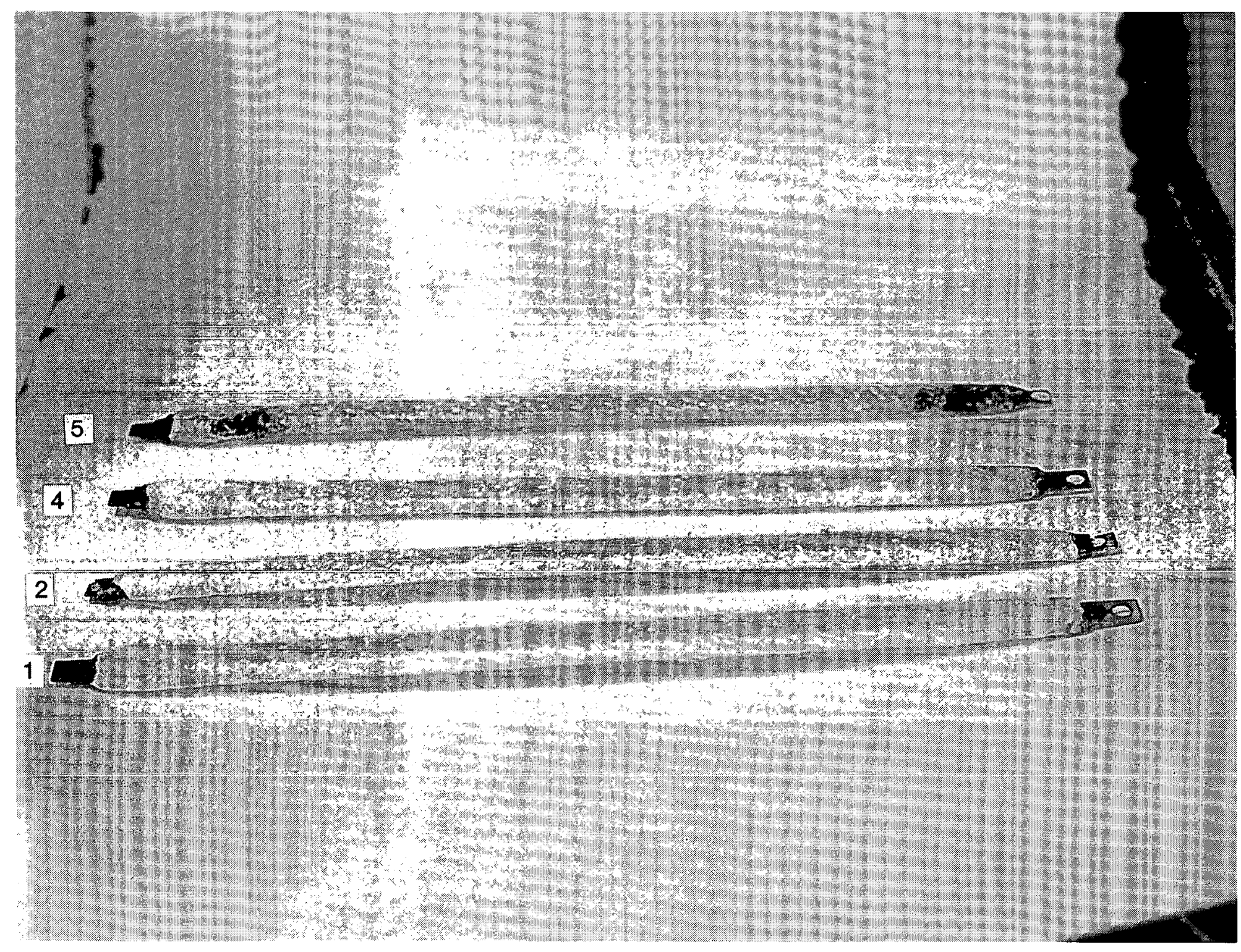

Fig. B2. Toshiba Bar Samples After Aging Tests 


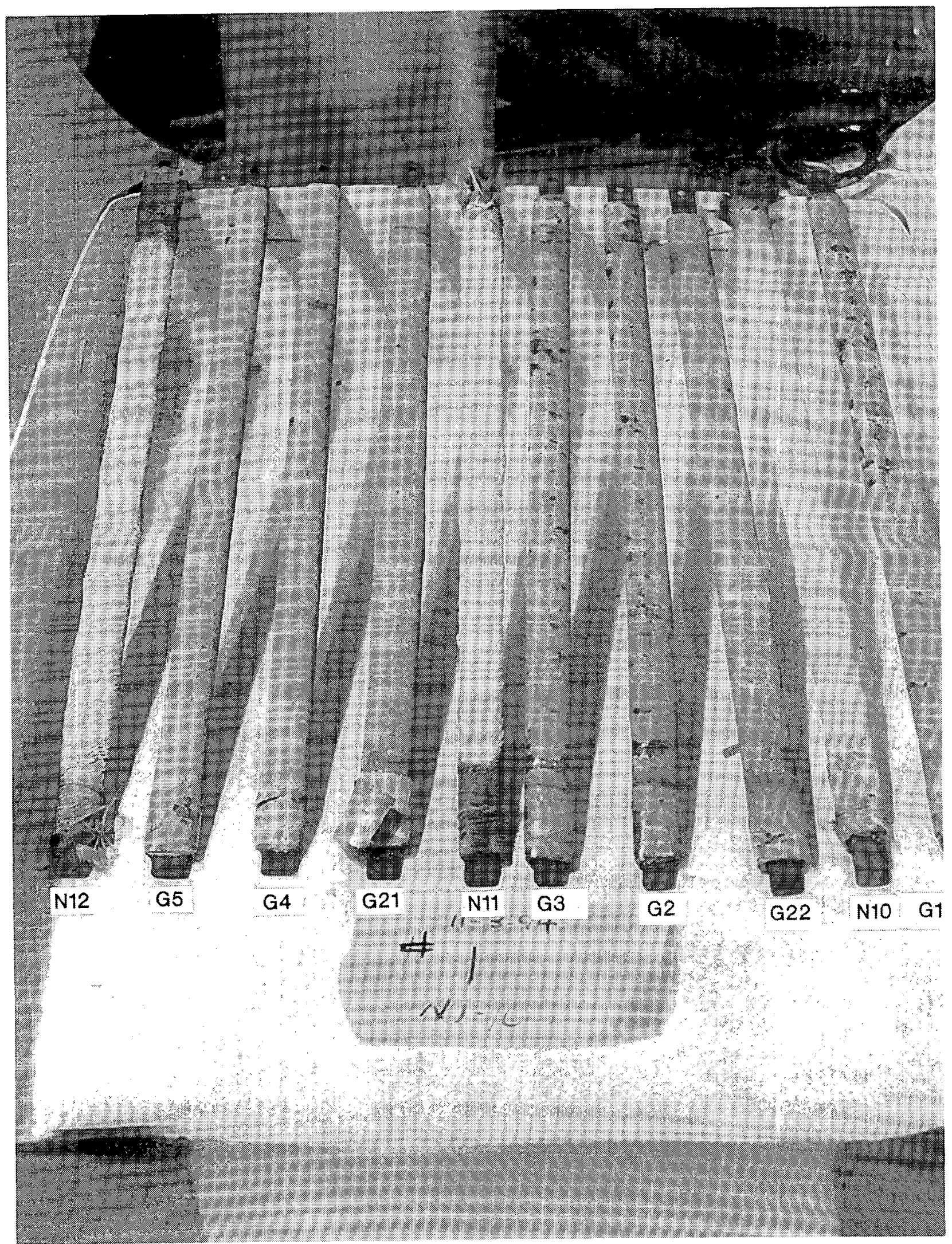

Fig. B3. General Electric Samples From Canister 1 After Irradiation 


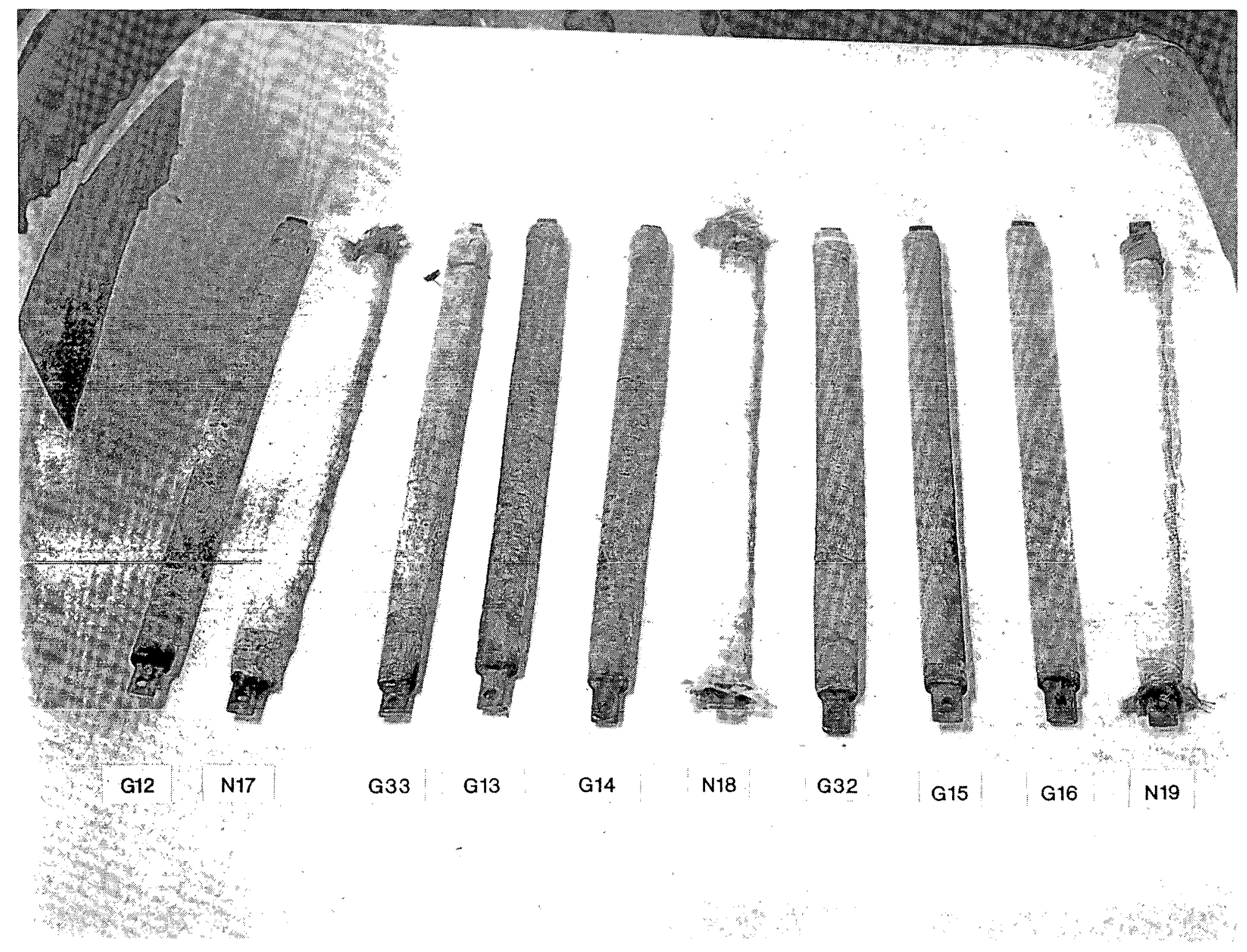

Fig. B4. General Electric Samples From Canister 3 After Irradiation 


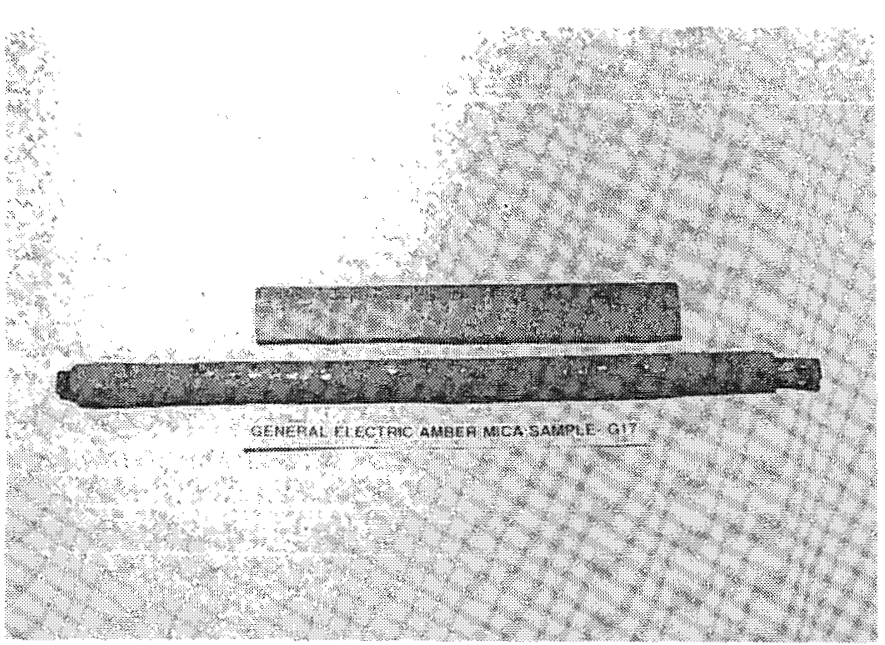

a. Sample G17 Before (ANL Neg. No. 15263K, Frame 10A)

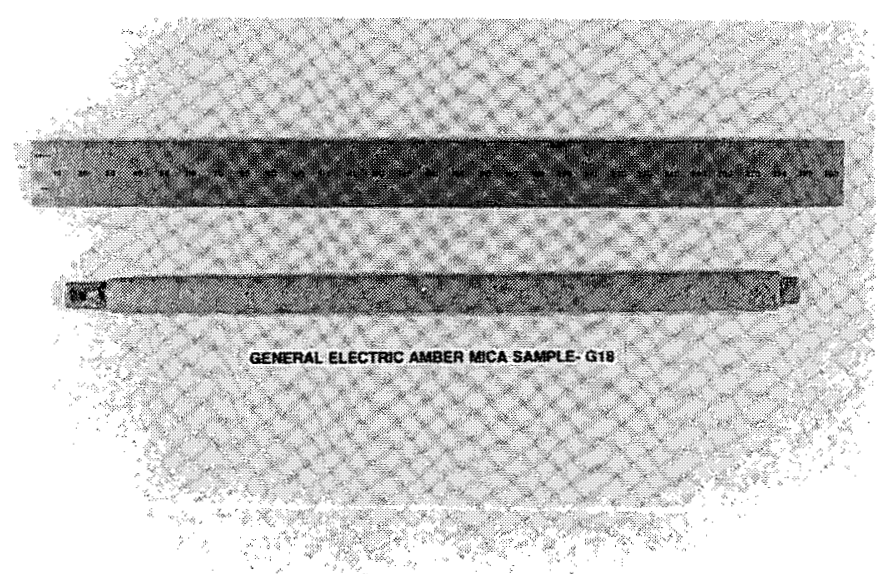

c. Sample G18 Before (ANL Neg. No. 15047, Frame 24)

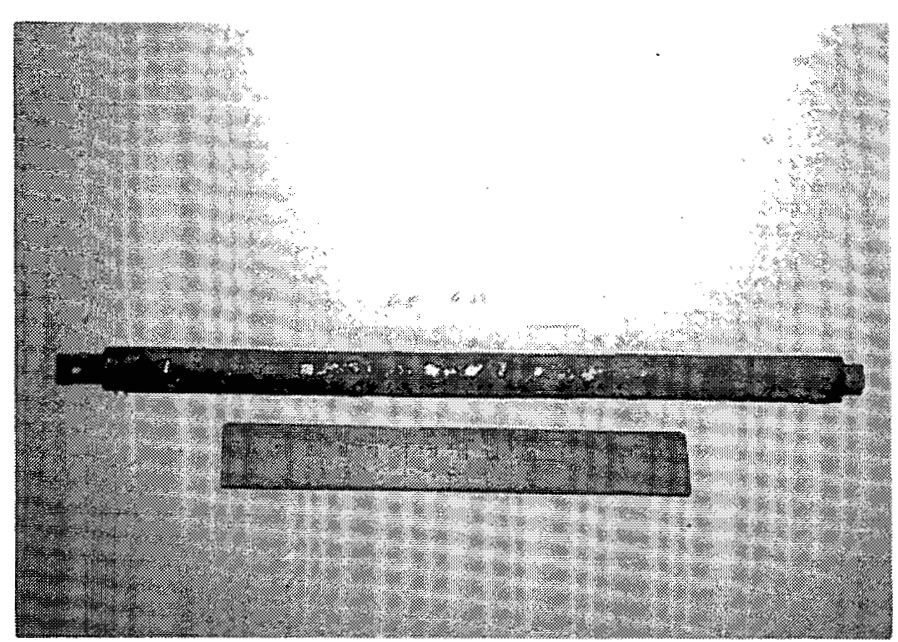

b. Sample G17 After (ANL Neg. No. 16375K, Frame 7A)

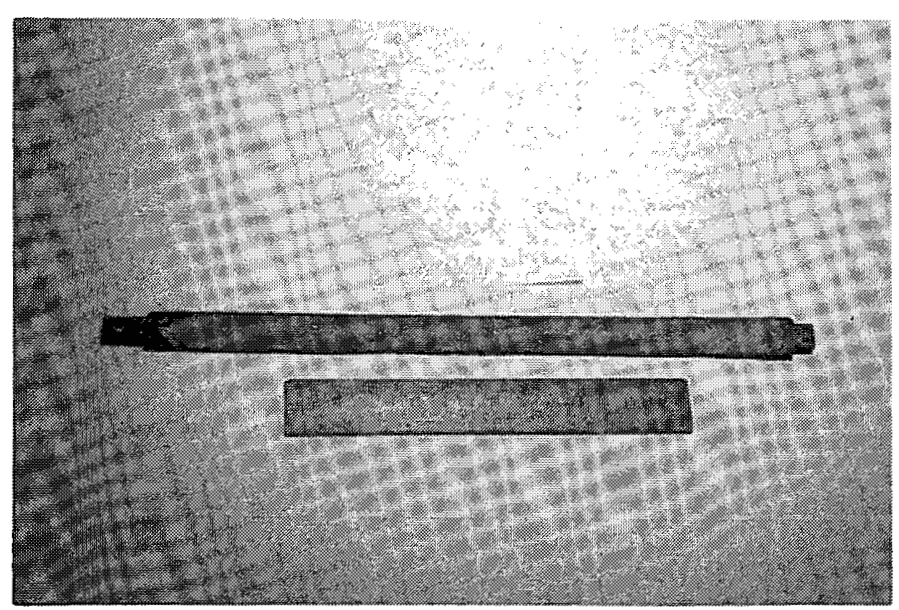

d. Sample G18 After (ANL Neg. No. 16375K, Frame 8A)

Fig. B5. General Electric Samples After Aging Tests 

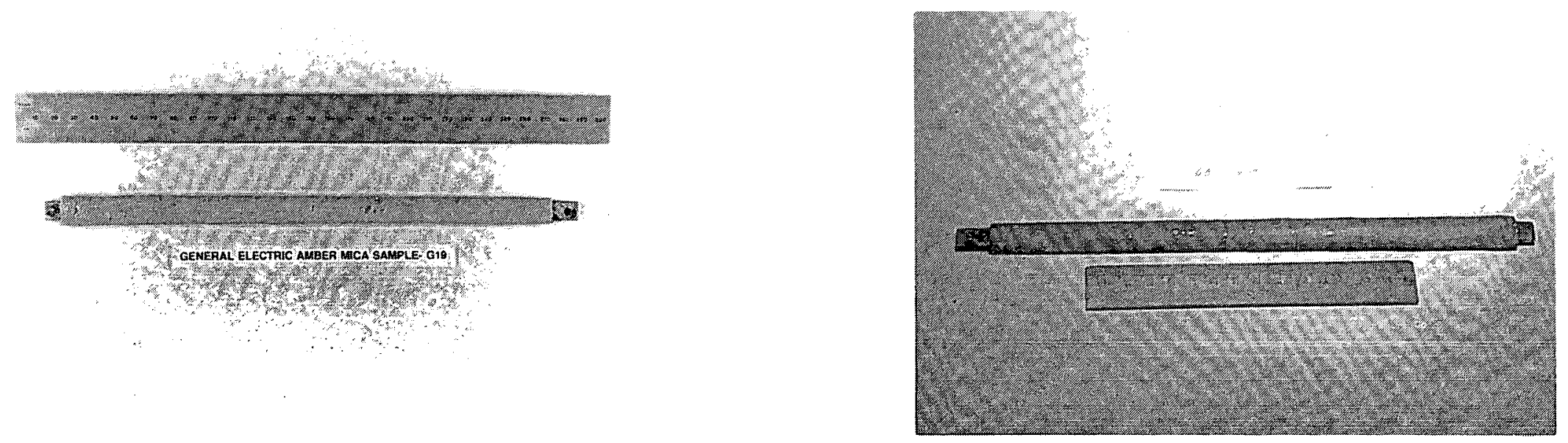

e. Sample G19 Before (ANL Neg. No. 15046, Frame 12)

f. Sample G19 After (ANL Neg. No. 16375K, Frame 9A)
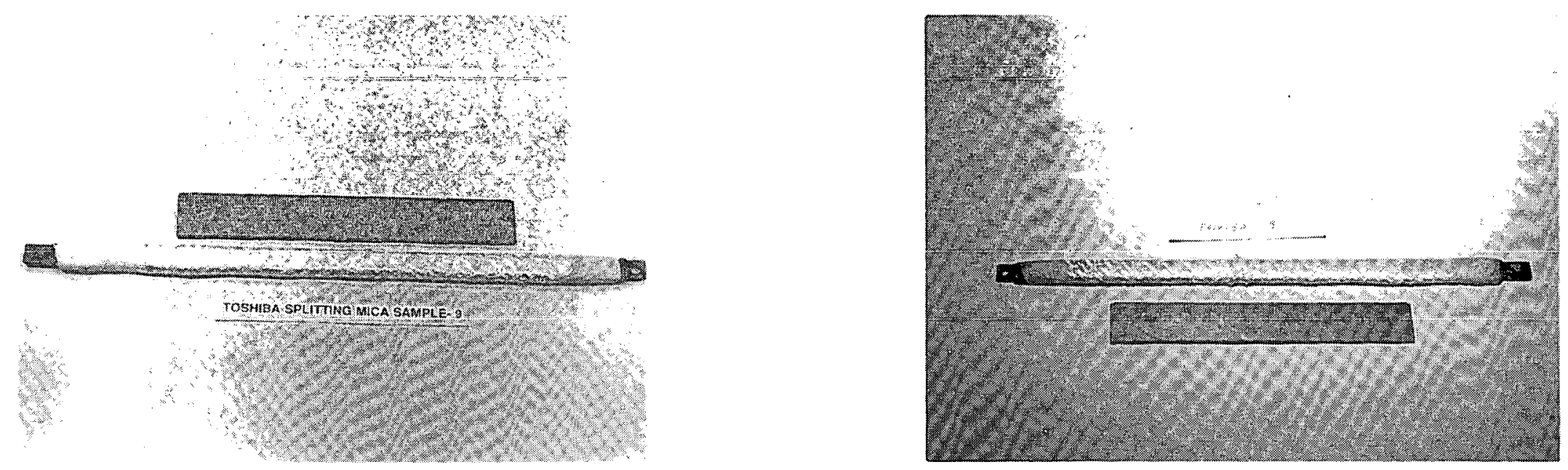

g. Sample Toshiba 9 Before (ANL Neg. No. 15314K, Frame 14A)

h. Sample Toshiba 9 After (ANL Neg. No. 16375K, Frame 17A)

Fig. B5. (Contd.) 


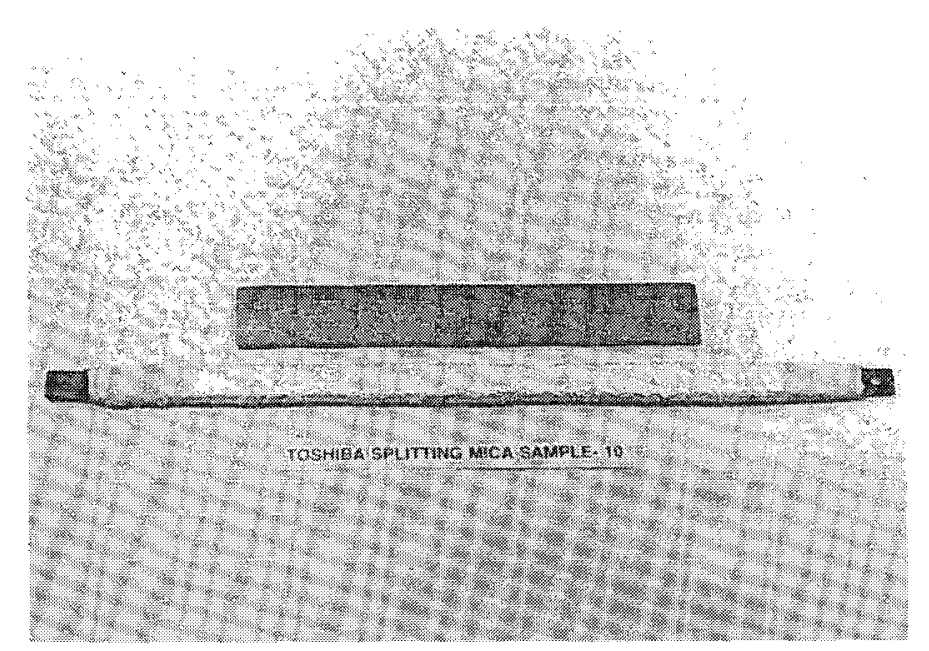

i. Sample Toshiba 10 Before (ANL Neg. No. 15314K, Frame 16A)

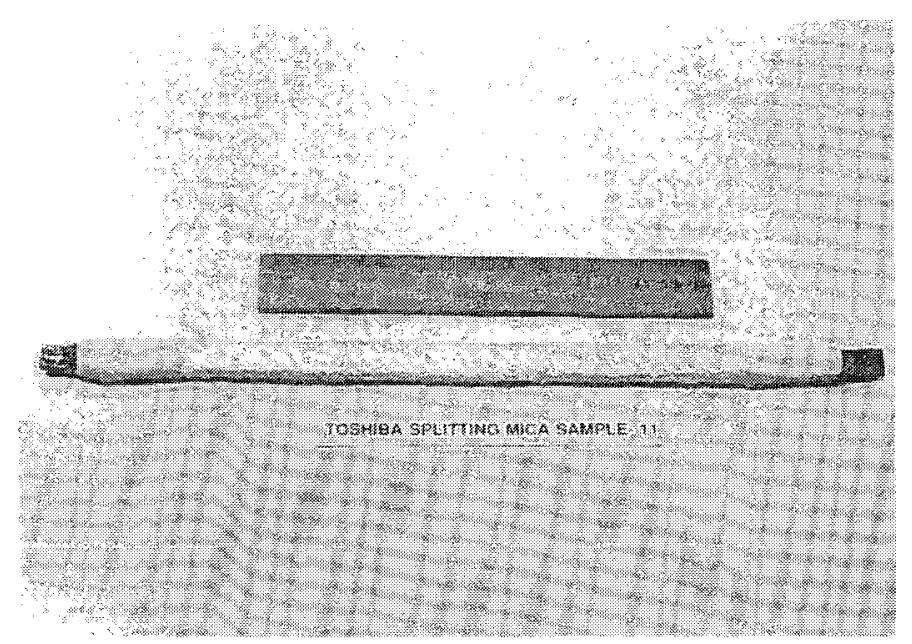

k. Sample Toshiba 11 Before (ANL Neg. No. 15314K, Frame 17A)

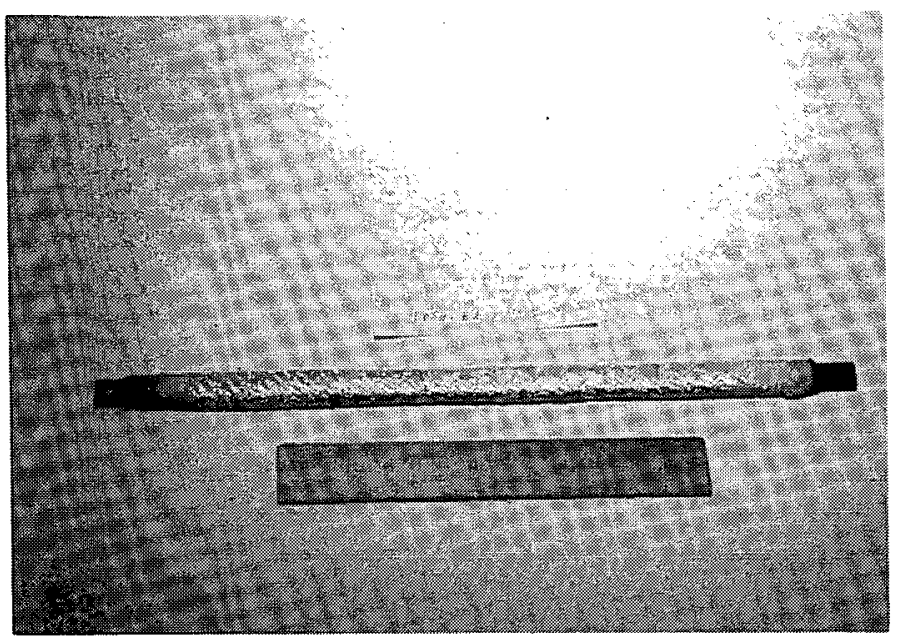

j. Sample Toshiba 10 After (ANL Neg. No. 16375K, Frame 18A)

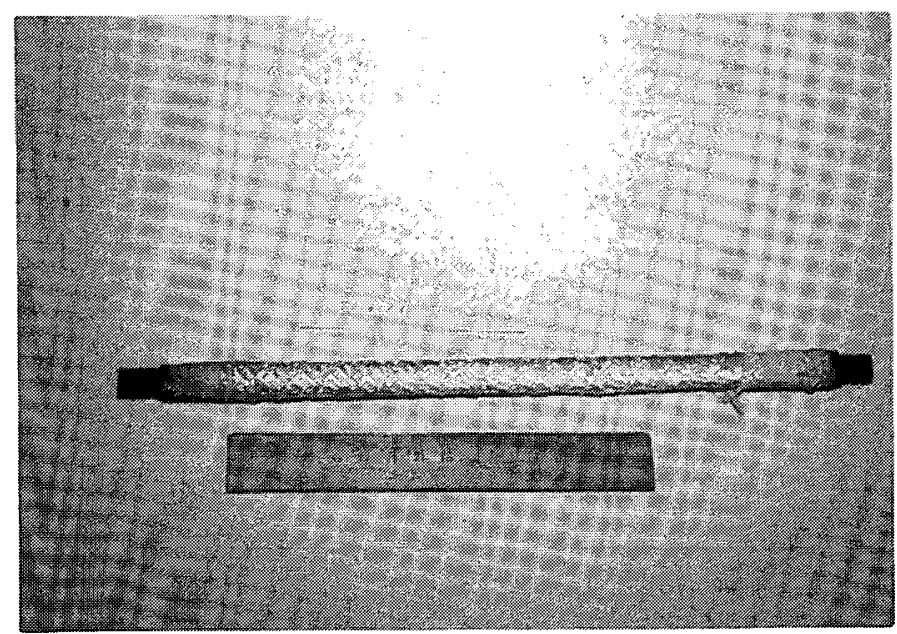

Fig. B5. (Contd.) 


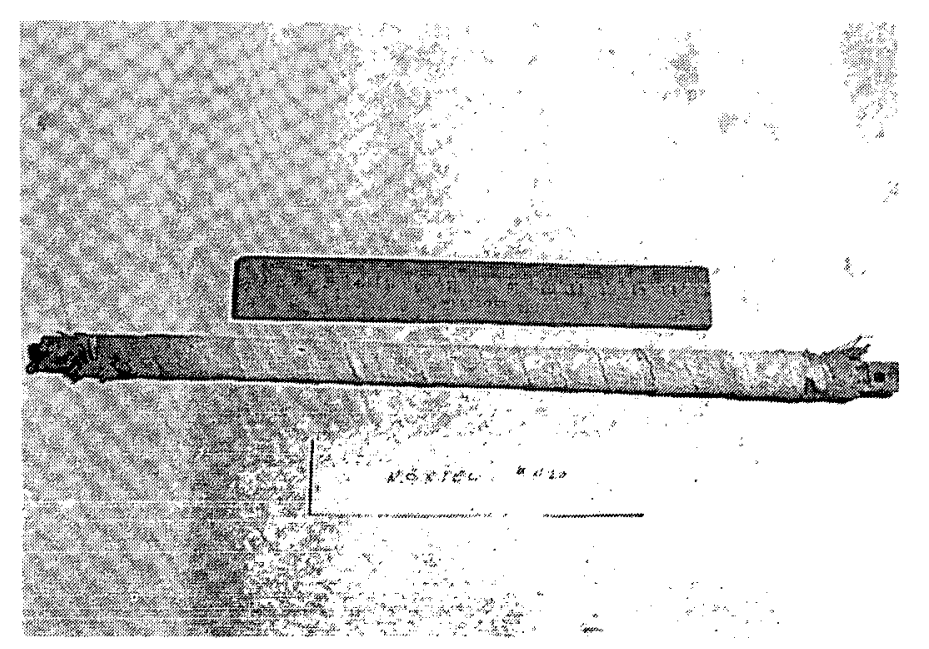

m. Sample N20 Before (ANL Neg. No. 15539K, Frame 7A)

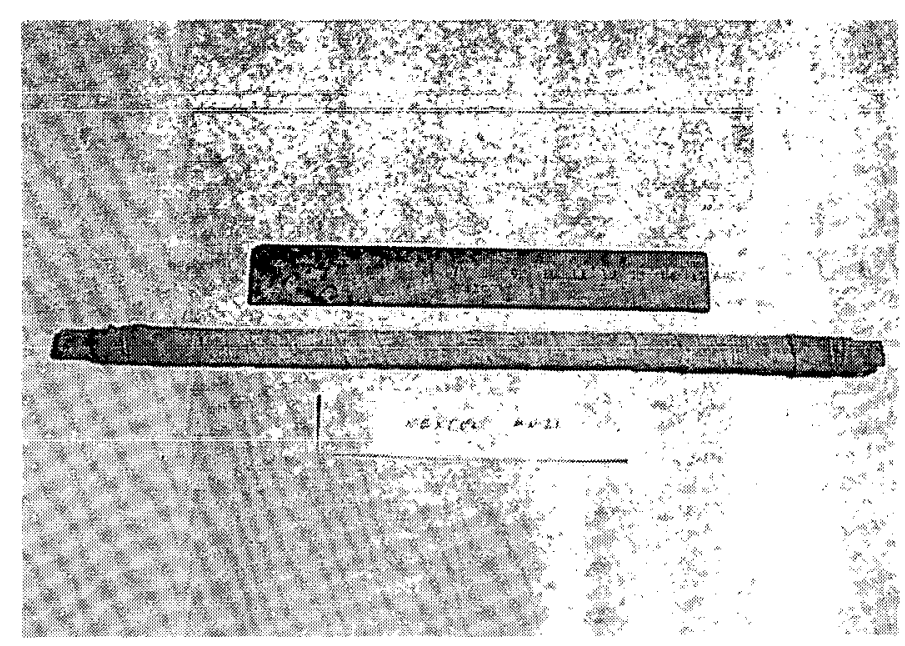

o. Sample N21 Before (ANL Neg. No. 15539K, Frame 8A)

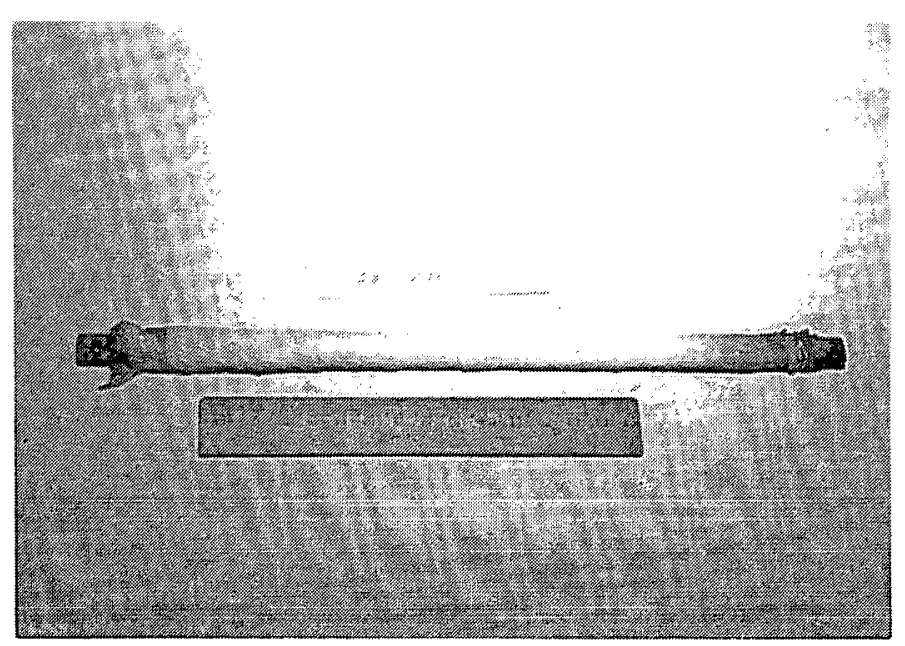

n. Sample N20 After (ANL Neg. No. 16375K, Frame 10A)

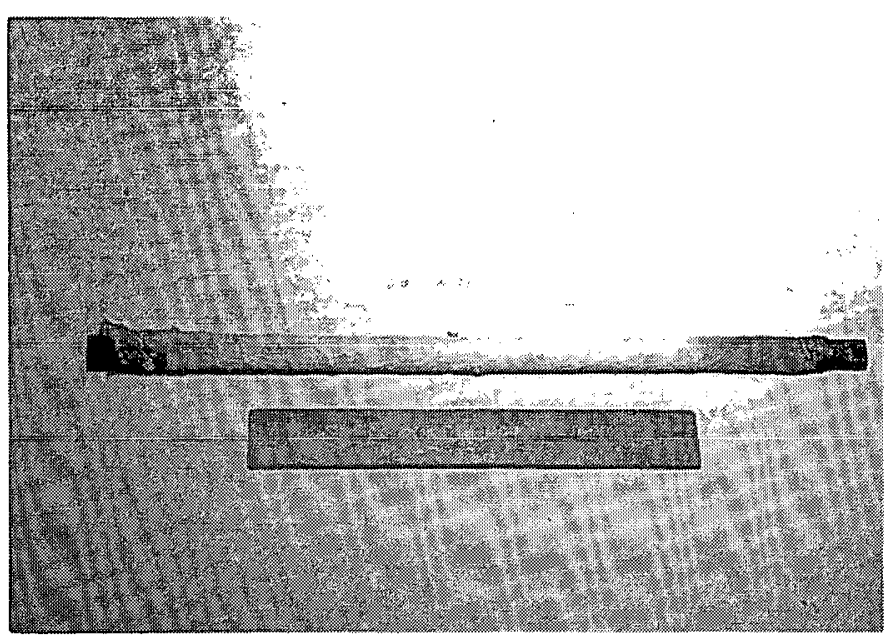

p. Sample N21 After (ANL Neg. No. 16375K, Frame 11A)

Fig. B5. (Contd.) 


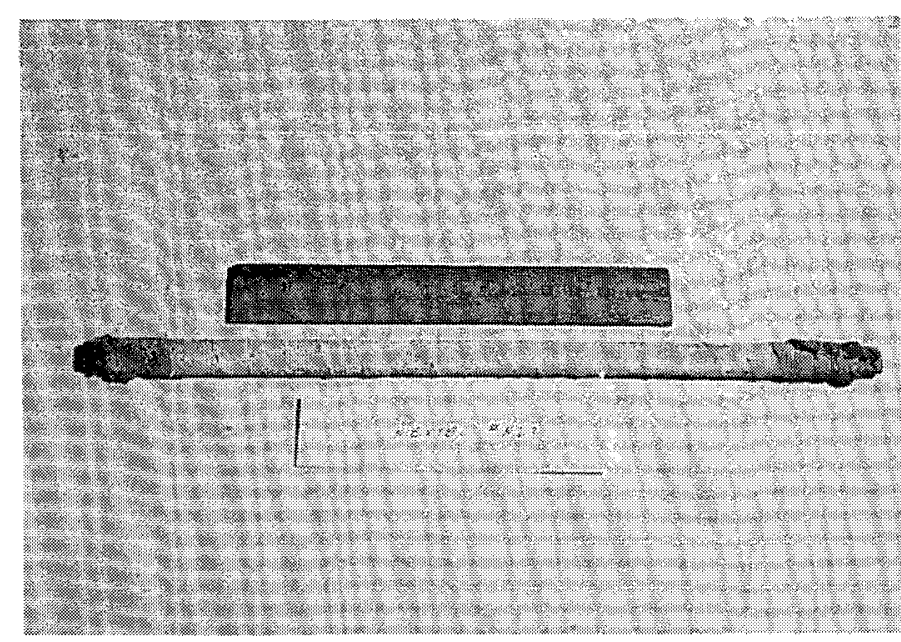

q. Sample N22 Before (ANL Neg. No. 15539K, Frame 9A)

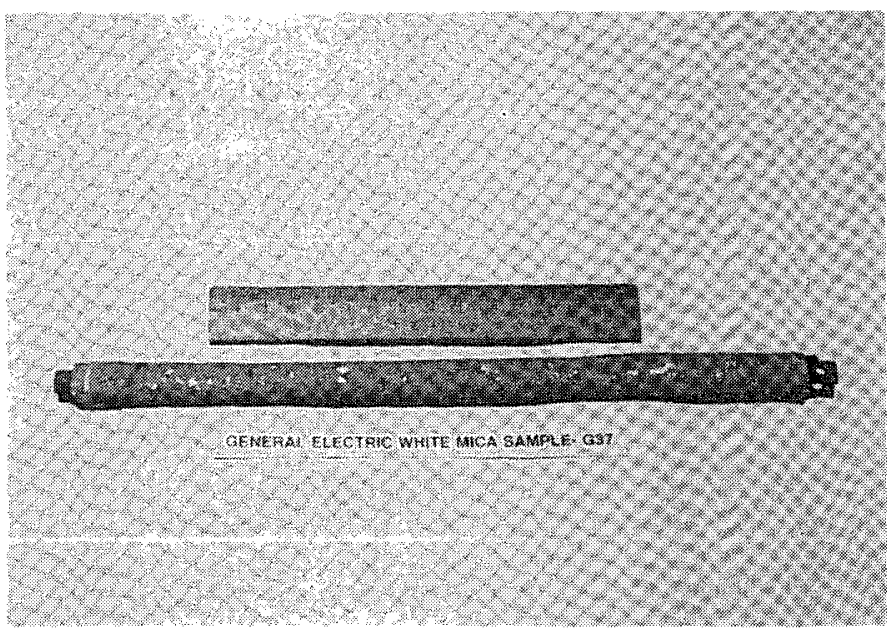

s. Sample G37 Before (ANL Neg. No. 15263K, Frame 22A)

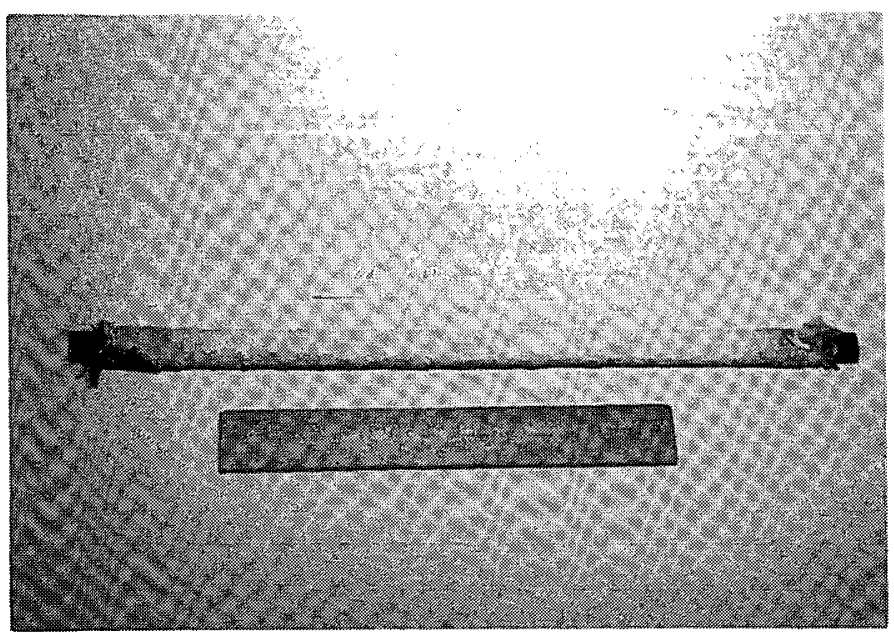

r. Sample N22 After (ANL Neg. No. 16375K, Frame 12A)

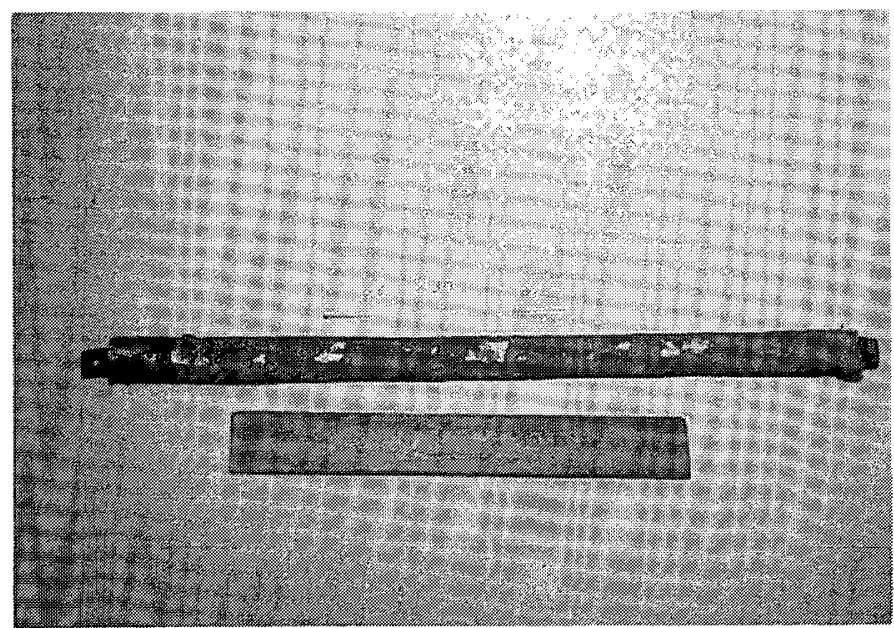

t. Sample G37 After (ANL Neg. No. 16375K, Frame 13A)

Fig. B5. (Contd.) 


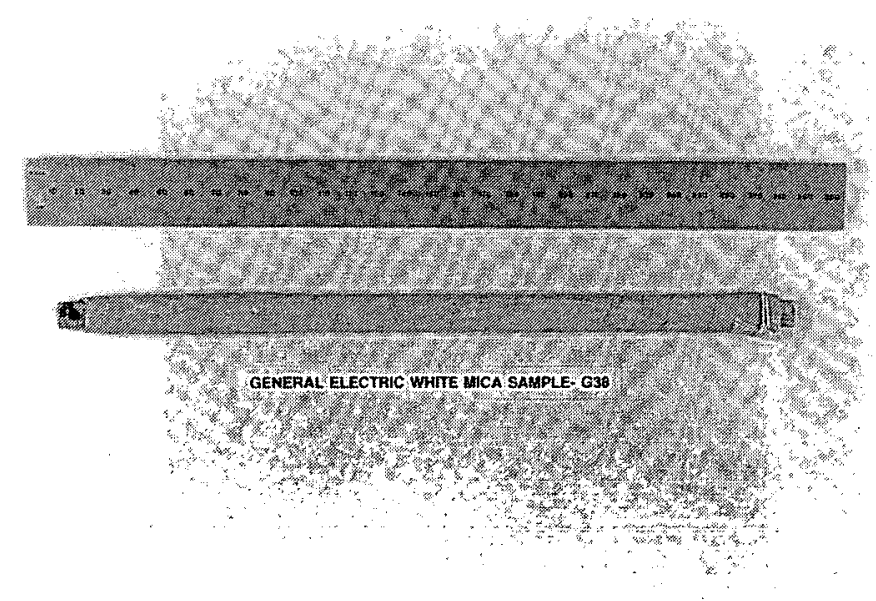

u. Sample G38 Before (ANL Neg. No. 15047, Frame 13)

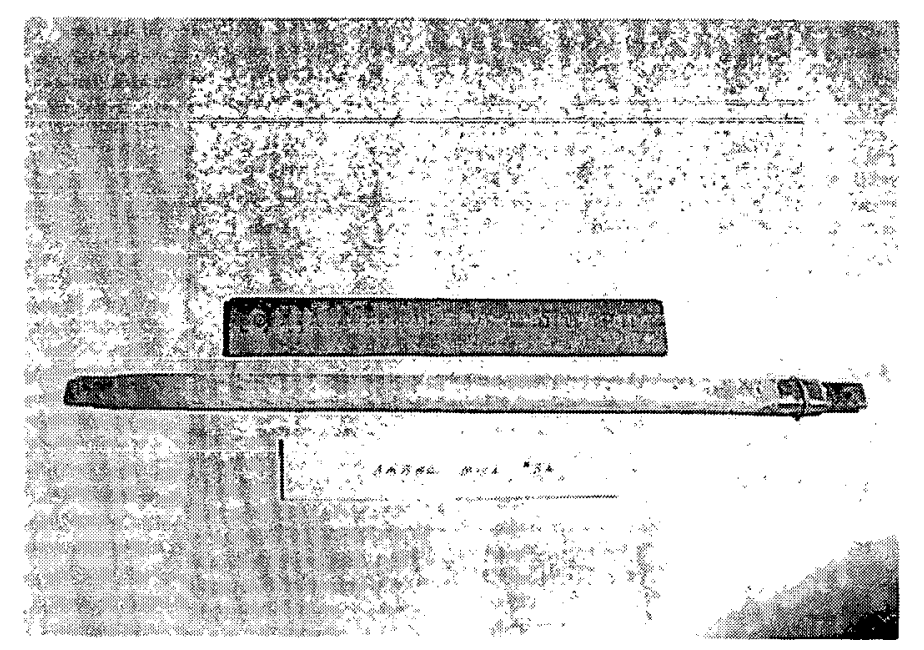

w. Sample 3A-92 Before (ANL Neg. No. 15539K, Frame 5A)

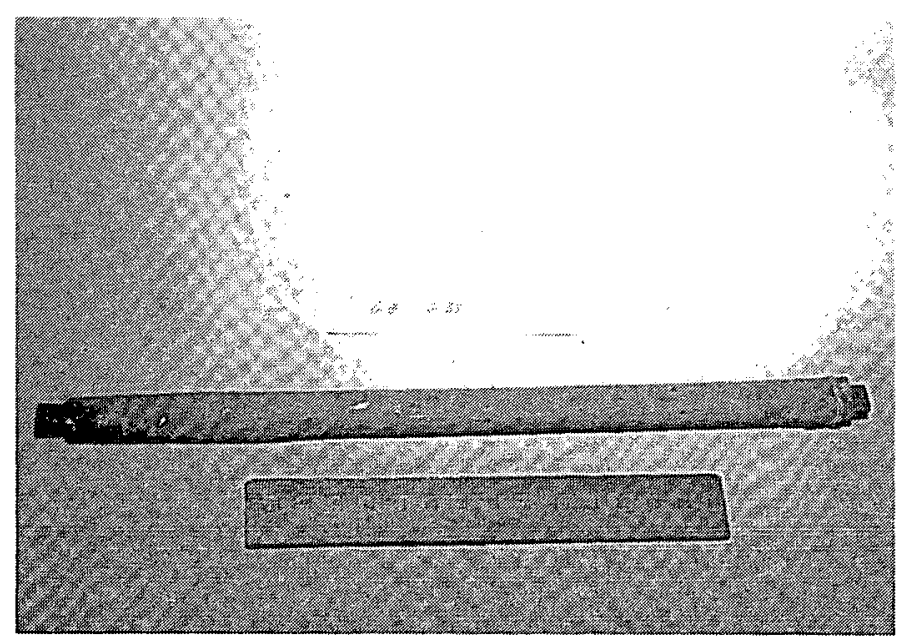

v. Sample G38 After (ANL Neg. No. 16375K, Frame 16A)

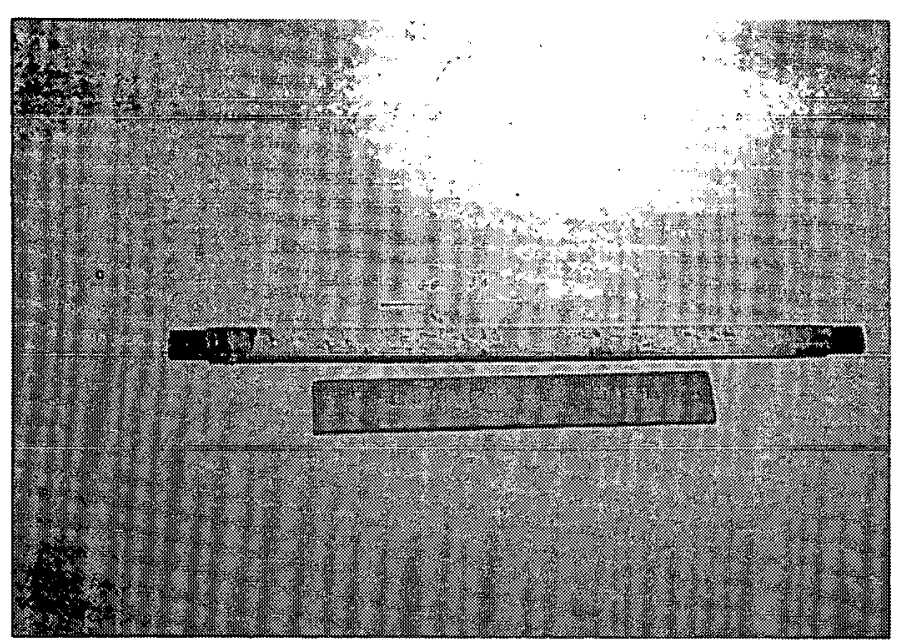

x. Sample 3A-92 After (ANL Neg. No. 16375K, Frame 5A)

Fig. B5. (Contd.) 


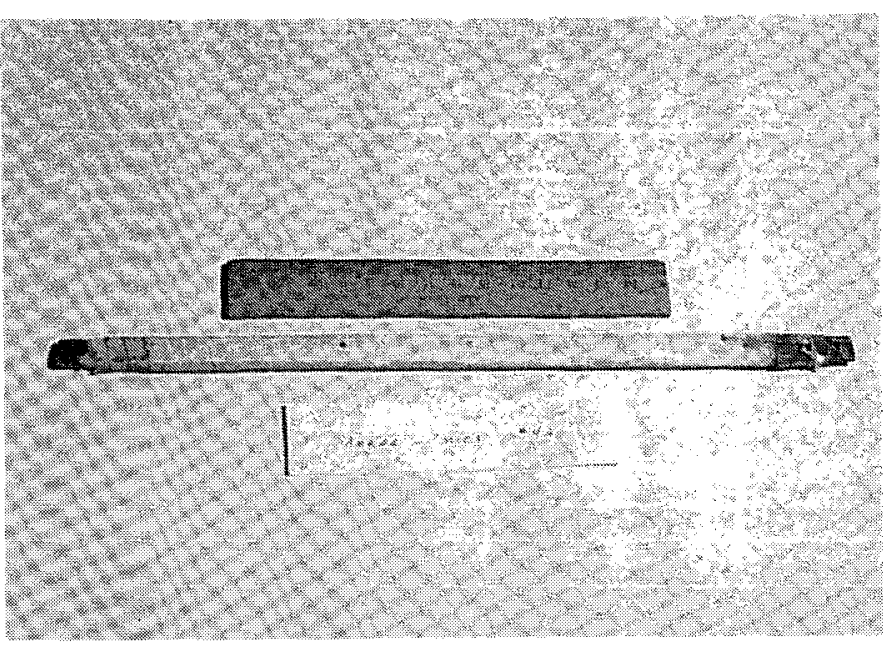

y. Sample 4A Before (ANL Neg. No. 15539K, Frame 6A)

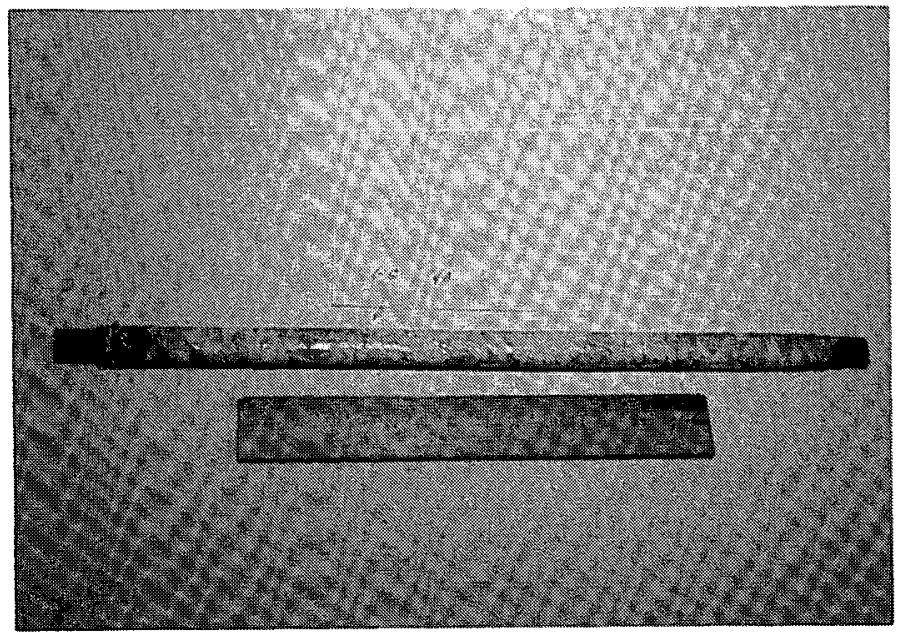

z. Sample 4A After (ANL Neg. No. 16375K, Frame 6)

Fig. B5. (Contd.) 


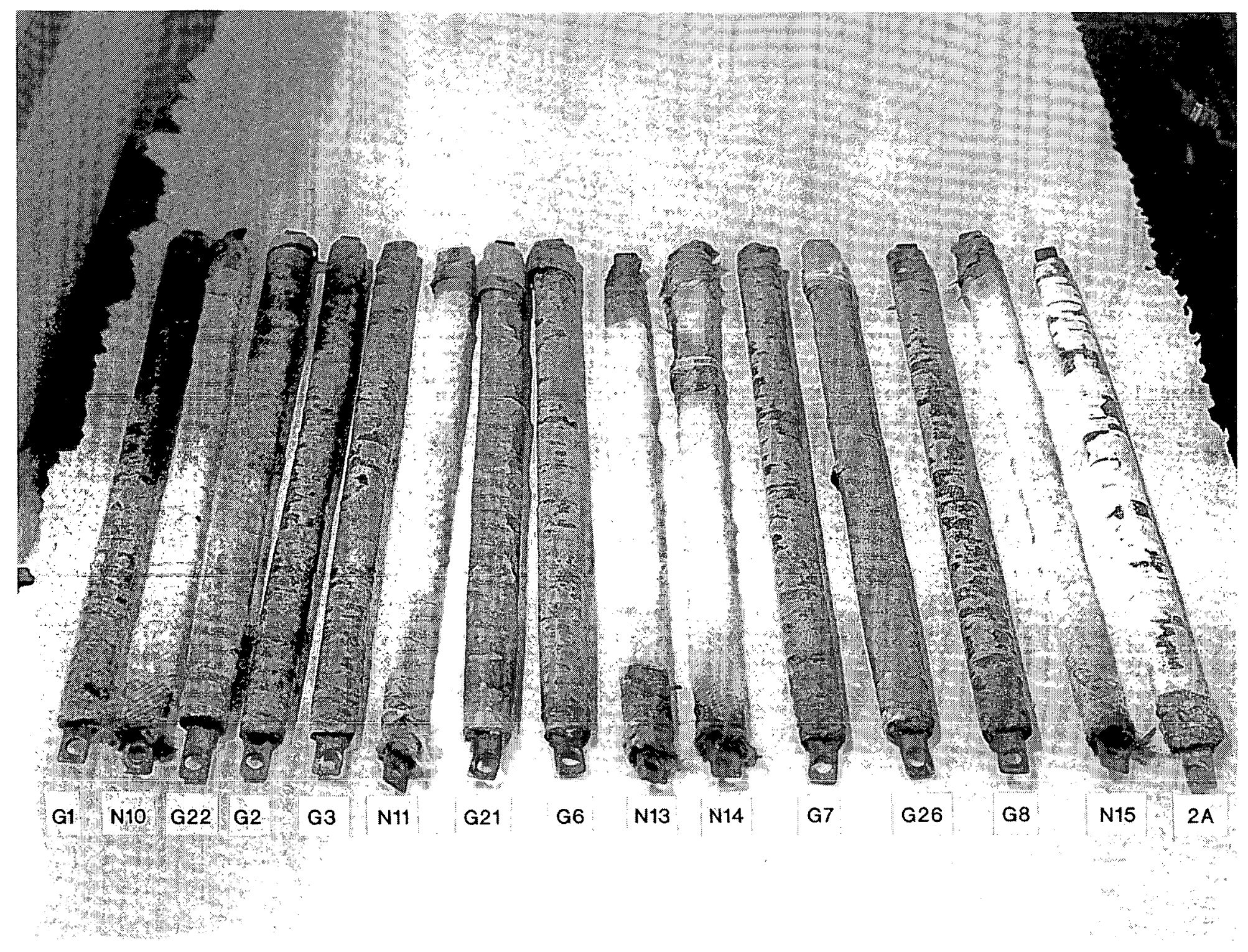

Fig. B6. Bar Samples Before and After Temperature Test 